\title{
African American farmers tilling for congressional attention: Exploring the agenda status of agricultural support policy and the hopeful permeations of civil rights (1940-1998)
}

\author{
Chaun A. Stores \\ West Virginia University
}

Follow this and additional works at: https://researchrepository.wvu.edu/etd

\section{Recommended Citation}

Stores, Chaun A., "African American farmers tilling for congressional attention: Exploring the agenda status of agricultural support policy and the hopeful permeations of civil rights (1940--1998)" (2005). Graduate Theses, Dissertations, and Problem Reports. 4195.

https://researchrepository.wvu.edu/etd/4195

This Dissertation is protected by copyright and/or related rights. It has been brought to you by the The Research Repository @ WVU with permission from the rights-holder(s). You are free to use this Dissertation in any way that is permitted by the copyright and related rights legislation that applies to your use. For other uses you must obtain permission from the rights-holder(s) directly, unless additional rights are indicated by a Creative Commons license in the record and/ or on the work itself. This Dissertation has been accepted for inclusion in WVU Graduate Theses, Dissertations, and Problem Reports collection by an authorized administrator of The Research Repository @ WVU.

For more information, please contact researchrepository@mail.wvu.edu. 


\title{
AFRICAN AMERICAN FARMERS TILLING FOR CONGRESSIONAL ATTENTION: EXPLORING THE AGENDA STATUS OF AGRICULTURAL SUPPORT POLICY AND THE HOPEFUL PERMEATIONS OF CIVIL RIGHTS (1940-1998)
}

\author{
Chaun A. Stores \\ Dissertation submitted to the \\ Eberly College of Arts and Sciences \\ at West Virginia University \\ in partial fulfillment of the requirements for the degree of \\ Doctor of Philosophy \\ in \\ Political Science \\ Professor Jeff S. Worsham, Ph.D., Chair \\ Professor Neil Berch, Ph.D. \\ Professor Scott R. Crichlow, Ph.D. \\ Professor John C. Kilwein, Ph.D. \\ Professor David G. Williams, Ph.D. \\ Department of Political Science \\ Morgantown, West Virginia \\ 2005
}

Keywords: Agenda-Setting, Congress, Subsystems, Agricultural Support Policy, Civil Rights 


\section{ABSTRACT \\ African American Farmers Tilling For Congressional Attention: Exploring The Agenda Status of Agricultural Support Policy And The Hopeful Permeations of Civil Rights (1940-1998)}

\section{Chaun Stores}

As with similar studies of agenda setting, this research builds on the work of Baumgartner and Jones (1993), King (1997), Worsham (1997), and Tzoumis (2001). Specifically, the focus of this study is on agricultural support policymaking - as it relates to African American farmers. Three fundamental objectives serve as the blueprint for the analysis. The first is to understand how Congress governs the agenda of agricultural support policy over the post-war period. Second, is to learn whether congressional activity is conducive to the interests of African American farmers and, third, is to assess if and when the agenda of agricultural support policy ever intersected with that of civil rights. Three qualifiers help facilitate and focus the analysis: (1) congressional committees are used as the venue of agenda-setting activity (2) bill introductions and (3) congressional hearings are used as the measures of agenda status and governmental attention.

The analysis in this dissertation derives from data collected on agricultural-related bills and hearings in Congress from 1940-1998. Through the utilization of both bill introductions and congressional hearings, general patterns of issue composition, committee competition, policy monopoly, and coalitional activity are fundamentally examined. In part, endogenous and exogenous punctuating events are evaluated according to the variation in these patterns.

The first chapter introduces the purpose and layout of the study. Chapter Two examines the evolution of agricultural policy and the travail it created for African American Farmers. This historical analysis will show that by the time New Deal politics produced new public policies, the direction of favoring large farmers was set and followed by government (Browne, 2003, 145). An important product of this accommodation made to large farming interests was the early arrangement of dominant subsystem politics, which consequently influences the direction of agricultural policy well into the late 1960s. Chapter Three describes the two perspectives of agenda setting. This chapter not only serves as a conduit to the research theory, but it also provides the backdrop for the next two analysis chapters.

Chapters Four and Five illustrate the agenda dynamics of agricultural support policy are influenced by the institutional actions of congressional committees/subsystems, policy entrepreneurs, as well as by endogenous and exogenous punctuating events. Findings will illustrate that although Agricultural Committees may serve as the institutional anchor for subsystem arrangement and policy monopoly, punctuating events tend to alter the policy equilibria maintained by such an arrangement. Moreover, such events can and do alter policy outputs as well.

Chapter Six of the research details how group pressure at the state and local level aided in bringing forth legislative assistance and governmental attention to the problems faced by African American farmers. However, due to the limited success and continued complaints of discrimination, African American farmers change venue and take their issue to the courts. As such, the later segment of this chapter details the current status of the class-action lawsuit brought against the United States Department of Agriculture (USDA), and how judicial action has yet to equate to institutional redress. Chapter Seven concludes the dissertation by examining how the research contributes to the understanding of agenda setting, and notes for further research. 


\section{ACKNOWLEDGEMENTS}

First and foremost I want to thank my Lord and Savior Jesus Christ for getting me through this very challenging and rewarding process. Without his grace and mercy none of this would have been possible. In addition, I also want to thank my wife for putting up with my constant discussion about agricultural policy. Her patience, understanding, and assistance were important in completing this research. Equally important, I want to acknowledge my committee chair and editorial bear, Professor Jeff Worsham. His interest, guidance, and critical review proved consequential in completing this research. Serving as my mentor, Dr. Worsham not only helped me grow as a graduate student, but he was always there to lend a word of encouragement and advice- - which was indeed invaluable. I also want to thank the rest of my committee, Professors Kilwein, Berch, Crichlow, and Williams for being so supportive throughout the process. I want to extend a special thanks to Dr. Crichlow for providing insight during the defense. Additionally, I want thank Dr. Grossback who was a member of the comprehensive testing committee. His direction and assistance was also vital in shaping the research. There is one other item on the agenda that I must acknowledge. My time working as a graduate assistant with Extension Service at Knapp Hall was also important in completing this research. My supervisor, Dr. Cote, not only provided me the opportunity to grow both academically and professionally, but he also allowed me to work on my dissertation when time was available - thanks Dr. Cote! Finally, I want to thank my family, friends, and colleagues for their support and encouragement. To everyone I mentioned and those I may have missed, I want to say thank you from the bottom of my heart. 


\title{
TABLE OF CONTENTS
}

\author{
Abstract \\ Acknowledgements $\quad$ iii \\ Table of Contents $1 v$ \\ List of Tables $v i$ \\ List of Figures $\quad v i i$ \\ Chapter 1: Introduction $\quad$ p. 1 \\ $\begin{array}{ll}\text { Chapter 2: } \text { The History and Tribulations of Agriculture } & \text { p. } 7\end{array}$ \\ For Black Farmers \\ The New Deal and Its Soiled Agricultural Adjustment Administration $\quad$ p. 13 \\ Agricultural Policy (Post New Deal) 1945-60 p. 16 \\ A Changing Political Environment $\quad$ p. 20 \\ Discrimination vs. Hope for Black Farmers $\quad$ p. 22 \\ $\begin{array}{ll}\text { Conclusion } & \text { p. } 28\end{array}$
}

$\begin{array}{ll}\text { Chapter 3: Agenda Setting and Issue Definition: } & \text { p. } 29\end{array}$

Disrupting Policy Equilibria

Theories of Agenda Setting and Government Policy p. 29

A Bottom-Up Perspective p. 32

A Top-Down Perspective p. 35

Agenda Status and Issue Definition p. 39

Theoretical Aim p. 44

$\begin{array}{lr}\text { Chapter 4: Tracking Agenda Status } & \text { p. } 46\end{array}$

$\begin{array}{ll}\text { Data Collection } & \text { p. } 47\end{array}$

Mapping the Agenda of Civil Rights $\quad$ p. 49

What Receives Attention p. 49

Who has Jurisdictional Control p. 55

Mapping the Agenda of Agriculture $\quad$ p. 61

What Receives Attention $\quad$ p. 61

Who has Jurisdictional Control p. 67

Sponsorship and Committee Competition p. 73

Policy-Coupling and Legislative Entrepreneurs p. 79

Success in 1990: The Minority Farmers Rights Act p. 81

$\begin{array}{ll}\text { Conclusion } & \text { p. } 84\end{array}$ 
$\begin{array}{ll}\text { Chapter 5: Analyzing Agricultural Agenda Setting p. } 86 & \text { A }\end{array}$

And Efforts of Issue Redefinition

Data Collection

Deciphering Agricultural Hearing Activity

p. 88

Witness Participation: Who Participates p. 97

Witness Activity p. 97

Policy-Coupling: Debating Civil Rights and Agriculture p. 104

Farm and Home Foreclosures p. 105

Civil Rights Enforcement Record of the Department of Agriculture p. 107

Decline of Minority Farming in the U.S. p. 110

Treatment of Minority Farming and Limited Resource Producers p. 112

Civil Rights Legislation and Other Issues $\quad$ p. 116

$\begin{array}{ll}\text { Conclusion } & \text { p. } 123\end{array}$

$\begin{array}{lr}\text { Chapter 6: } & \text { The Last Toil For Redress } 126\end{array}$

Groups Pressure the USDA p. 127

Order from the Court p. 131

$\begin{array}{ll}\text { Conclusion } & \text { p. } 139\end{array}$

$\begin{array}{lr}\text { Chapter 7: Concluding Comments } & \text { p. } 140\end{array}$

$\begin{array}{lr}\text { References } & \text { p. } 144\end{array}$

Appendix: 


\section{LIST OF TABLES}

$\begin{array}{lll}\text { Table 1.1 } & \text { U.S. Farms Operated by Blacks and Whites } & \text { p. } 2 \\ \text { Table 2.1 } & \text { Summary of Agricultural Acts } & \text { p. } 27 \\ \text { Table 4.1 } & \text { Civil Rights Introductions by Session } & \text { p. } 51 \\ \text { Table 4.2 } & \text { Agricultural Bill Introductions by Session } & \text { p. } 62 \\ \text { Tables 4.3, 4.5 } & \text { House Committee Referral and Sponsorship } & \text { p. } 74,77 \\ \text { Tables 4.4, 4.6 } & \text { Senate Committee Referral and Sponsorship } & \text { p. } 75,78 \\ \text { Table 5.1 } & \text { Policy-Coupled Hearings: Witness Comparison } & \text { p. } 120 \\ \text { Table 6.1 } & \text { Consent Decree Claims } & \text { p. } 136\end{array}$




\section{LIST OF FIGURES}

Figure 4.1 Civil Rights Introductions p. 52

Figure 4.2 House Civil Rights Bill Introductions $\quad$ p. 53

$\begin{array}{lll}\text { Figure } 4.3 & \text { Senate Civil Rights Bill Introductions }\end{array}$

Figure 4.4 House Civil Rights Bill Referral p. 56

$\begin{array}{lll}\text { Figure } 4.5 & \text { Senate Civil Rights Bill Referral } 57\end{array}$

$\begin{array}{lll}\text { Figure } 4.6 \quad \text { House Herfindahl } & \text { p. } 59\end{array}$

$\begin{array}{lll}\text { Figure } 4.7 & \text { Senate Herfindahl } & \text { p. } 60\end{array}$

Figure $4.8 \quad$ Agricultural Bill Introductions $\quad$ p. 63

$\begin{array}{lll}\text { Figure } 4.9 & \text { House Agricultural Bill Introductions } & \text { p. } 65\end{array}$

$\begin{array}{lll}\text { Figure } 4.10 \quad \text { Senate Agricultural Bill Introductions } & \text { p. } 66\end{array}$

$\begin{array}{lll}\text { Figure } 4.11 \quad \text { House Agricultural Bill Referral } & \text { p. } 68\end{array}$

$\begin{array}{lll}\text { Figure } 4.12 \quad \text { Senate Agricultural Bill Referral } & \text { p. } 69\end{array}$

$\begin{array}{lll}\text { Figure } 4.13 \text { House Herfindahl } & \text { p. } 71\end{array}$

$\begin{array}{lll}\text { Figure } 4.14 & \text { Senate Herfindahl } & \text { p. } 72\end{array}$

$\begin{array}{lll}\text { Figure } 5.1 \quad \text { Hearing Comparison } & \text { p. } 91\end{array}$

Figure 5.2 House Committee Competition p. 92

$\begin{array}{lll}\text { Figure } 5.3 & \text { Senate Committee Competition } 93\end{array}$

Figure $5.4 \quad$ House Herfindahl p. 95

$\begin{array}{lll}\text { Figure } 5.5 & \text { Senate Herfindahl p. } 96\end{array}$

$\begin{array}{lll}\text { Figure 5.6 House Witness Participation } 101 & \text { p. } 101\end{array}$

$\begin{array}{lll}\text { Figure } 5.7 & \text { Senate Witness Participation } 102\end{array}$

$\begin{array}{lll}\text { Figure 5.8 Hearing Activity and Agricultural Legislation } & \text { p. } 123\end{array}$ 


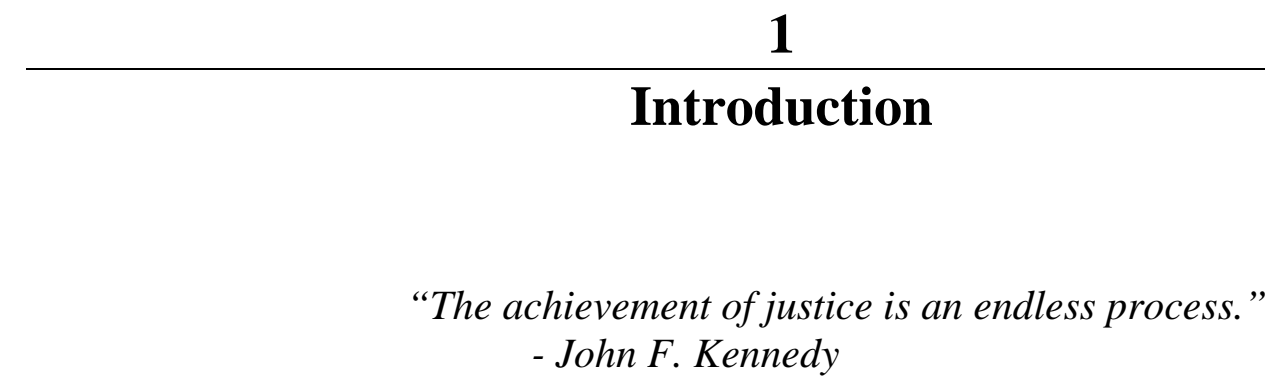

In 1997, more than 1,000 African American farmers initiated the Timothy Pigford, et al. v. Glickman class action lawsuit, requesting over $\$ 2$ billion in compensation for discrimination by the United States Department of Agriculture (USDA) between the years 1983 and 1997. The lawsuit alleges that the USDA purposely mishandled and denied loan applications and disaster relief to black farmers solely on the basis of race. Representative Maxine Waters (D-CA) testified at a congressional hearing on the issue in 1997 that the USDA has been bogged down with bureaucrats who have routinely discriminated against African American farmers (Knight, 2000).

On January $5^{\text {th }} 1999$, the USDA sought to settle the lawsuit by agreeing to pay $\$ 50,000$ to every black farmer who could substantiate a claim of discrimination by the agency through the denial of government loans/credit as well as disaster relief assistance. Unfortunately, many of these farmers had already lost their land, unlike their white counterparts. As table 1.1 illustrates, the rate of decline by black farm operators between 1900 and 1997 is noticeably greater than that of their white counterparts. 
Table 1.1: U.S. Farms Operated by Blacks and Whites, 1900-1997

\begin{tabular}{|r|r|r|l|l|r|}
\hline \multicolumn{1}{|l|}{ Year } & Blacks & \% Change & & \multicolumn{1}{l|}{ Whites } & \% Change \\
\hline 1997 & 18,451 & -1.9 & & $1,882,652$ & -0.9 \\
\hline & & & & & -8.0 \\
\hline 1992 & 18.816 & -18.0 & & $1,900.63$ & -6.5 \\
\hline 1987 & 22,954 & -31.0 & & $2,064,805$ & -8 \\
\hline & & & & & -22.4 \\
\hline 1982 & 33,250 & -41.9 & $2,207,726$ & \\
\hline 1978 & 57,271 & -57.3 & $2,398,726$ & -9.6 \\
\hline & & & & & -28.8 \\
\hline 1969 & 133,973 & -50.8 & & $3,089,885$ & -10.7 \\
\hline 1959 & 272,541 & -51.3 & $3,419,672$ & 0.1 \\
\hline 1950 & 559,980 & -17.9 & & $4,802,520$ & -2.3 \\
\hline 1940 & 681,790 & -22.8 & $5,378,913$ & 1.1 \\
\hline 1930 & 882,852 & -4.6 & $5,373,703$ & 9.5 \\
\hline 1920 & 925,710 & 3.6 & $5,499,707$ & \\
\hline 1910 & 893,377 & 19.6 & $5,440,619$ & \\
\hline 1900 & 746,717 & & & $4,970,129$ & \\
\hline \multicolumn{7}{|r|}{} & & & & -65.8 \\
\hline
\end{tabular}

Source: Spencer Wood and Jess Gilbert, "Returning African American Farmers to the land: Recent trends and policy rationale.” Source for 1900-1978: United States Commission on Civil Rights, 1982:3. Sources for 1982-1997: 1992 Census of Agriculture: Geographic Series 1B, CD-ROM and 1997 Census of Agriculture: Geographic Series 1B.

In an effort to understand how the problems faced by African American farmers are linked to the actions of government, it is important to examine the agenda in which policies were initiated and created. William Browne $(2003,130)$ argues that government exacerbates the existence of discrimination when "it creates policies to keep certain types of farmers in business, while ignoring farmers characteristic of a certain race.” Gilbert and Eli $(2000,149)$ emphasize that since land ownership had historically been an issue of racial tension in the South, most white congressmen in the House and the Senate were antagonistic when it came to initiating and supporting policies intended to provide landownership and property to African American farmers. Browne (2003) suggests 
agriculture for black farmers became more difficult when government sought to modernize and develop the farm sector. After the late 1940s, when industrialization was impacting agriculture, agricultural policy was the epitome of pluralism in which various groups and interests were readily accommodated (Sheingate, 2001; Hansen, 1991; Browne, 1988). This may very well be the case; however, if the interests of African American farmers were routinely excluded during the agenda setting of agricultural policy, the extent of pluralism can be questioned. As such, taking a closer look at postNew Deal agricultural policy is important to understanding the challenges faced by black farmers.

The historic agenda of agriculture focused on increased production, competitive markets, and the option for individual farmers to profit from such circumstances. Once the Great Depression hit, it was transformed to one of relief, recovery, and reform (Paarlberg 1989, 41). Government intervention was utilized to establish and maintain farm stability primarily among large farm producers. As a result, the dilemma faced by small farmers was to avoid displacement, while striving for a piece of prosperity. The road traveled by African American farmers came with far more struggles and turmoil. As African Americans moved from slave to freedmen, expectations of acquiring land and living as a free independent farmer was full of disappointment and episodic despair. In part, the issue of race placed African American farmers outside the social order by which government is inherently influenced. ${ }^{1}$ Under such circumstances, race along with their inability to influence policy makers, precluded this group of farmers from having their

\footnotetext{
${ }^{1}$ Assertion taken from Rogers M. Smith 1997 Civic Ideals pp 41 in which he details how race prohibited slaves from being part of society, and thus considered as an "outsider."
} 
immediate and long term needs immediate and long term needs addressed by government.

In government's attempt to address an issue, perceptions of the problem are debated and the level of attention it receives may be indefinite. Groups and actors within and outside of government actively work to have policy fit their needs. In such an attempt there are bound to be winners and losers. Subsequently, the focus of my research explores (1) how Congress manages the agenda of agricultural support policy over the postwar period, (2) whether such management was conducive to the interests of African American farmers, and (3) if the agenda of such policy ever intersected with that of civil rights.

This research examines the agenda of agricultural support policy and whether such policy was ever defined in the context of civil rights. A central concern is to explore how Congress governs the agenda of agricultural support policy over the post-war era. The interest in this question is to analyze the institutional factors that influenced the agenda of agricultural support policy of special concern to African American farmers. Second, posing this question is important because it forces one to explore the linkage between racial equality and public policy as it relates to aspects of agenda setting. Thus, the question is worth answering because it reveals the discrepancy between policy, its development, and subsequent implementation.

The implementation or effectiveness of agricultural policy aimed at assisting farmers is not assessed, but rather I explore congressional agenda setting and its interrelationship with the minority farming community. In doing so, my research accomplishes three fundamental goals. First, it examines agricultural policy in the context of agenda setting. Second, it determines whether and when the agenda of 
agricultural support policy primarily reflected the interests of large landowners or agribusiness. Last, it explores if, when, and how the interests of African American farmers entered the process.

In hopes of meeting these objectives, the research is structured according to six areas of discussion and analysis. In Chapter Two, I begin my exploration by examining the period from Reconstruction leading up to the New Deal. This discussion highlights the efforts made to aid black agriculture and the resultant backlash. The next section examines post-New Deal activities and decisions of government in the realm of agriculture, and the influential political actors and beneficiaries responsible for its development. This section illustrates how the development and change in agricultural policy was influenced by numerous political groups and or actors. Equally important, it highlights the ramifications of agricultural policy being influenced and shaped by deep core beliefs held by select interests, thus in turn allowing for negative externalities to be shouldered primarily by less influential interests. Moreover, Chapter Two is significant because it seeks to accentuate the research question and its overall contribution.

Chapter Three begins by describing the two perspectives to agenda setting. This discussion serves as a conduit to developing the research theory; which is explicitly presented in the later portion of the chapter. Providing this discussion highlights the systems/meso-level framework of the study. Chapters Four and Five illustrate how agenda dynamics in agriculture are influenced by the institutional actions of congressional committees/subsystems, policy entrepreneurs, as well as by endogenous and exogenous punctuating events. 
Particularly, Chapter Four tracks the agenda status of agricultural policy and civil rights by focusing on legislative bill introductions. Serving as the segue into Chapter Five, this discussion examines and compares the level of attention that both the House and Senate give to agricultural support policy and civil rights issues. In addition, this chapter tracks the referral of agricultural bill introductions and the activity of policy entrepreneurs. The purpose of this analysis is to explore policy jurisdiction, as well as the instances in which civil rights is introduced within agriculture, and the policy entrepreneurs responsible for such coupling.

Chapter Five expands on the importance of committee turf by detailing how the policy monopoly held by the Agriculture Committees can serve to restrict the variety of interests involved in policymaking. Agricultural Committees may serve as the institutional anchor for subsystem arrangement and policy monopoly, but punctuating events can and do alter the equilibria established by such an arrangement. Moreover, not only can equilibria be disrupted, but such events can and do alter policy outputs as well. As a result, the potential for policy coupling is strengthened but not infallible. Finally, Chapter Six discusses how group pressure at the state and local level contributed in bringing forth assistance and attention to the problems faced by black farmers. This chapter closes by describing the current status of the court settlement between the United States Department of Agriculture (USDA) and African American farmers, and how judicial action has been indefinite in instituting redress for the many years of discrimination. Chapter Seven highlights how my research contributes to the understanding of agenda setting as it relates to agricultural policy and African American farmers, and the steps that can be taken for future research. 


\section{2}

\section{The History and Tribulations of Agriculture For Black Farmers}

"The freedmen had got the impression that the abandoned lands of their old owners were to be divided amongst them. Their impressions arose from the talk they had heard around them by the white and colored soldiers."

-Elizabeth Hyde Botume (1893, 170)

Racial discrimination and inequality involving African American farmers has a long history, dating as far back as 1863 with the Emancipation Proclamation. The passage of the Proclamation granted nearly 4 million slaves freedom; but it did not guarantee nor define their role as a laboring force in the South. In January of 1865 General William T. Sherman's Field Order \#15 deeded almost a half-million acres of land to black families in Georgia, South Carolina and on the Florida coasts (Magdol 1977, 139). In an effort to limit the overwhelming backlash from white southerners, Congress decided not to confirm Sherman's grant, and instead enacted The Freedmen's Bureau bill. The bill included a compromise offer to lease abandoned land to freedmen with the option to purchase the land with their profits at low prices within three years (Smith 1997, 300; Magdol 1977, 139).

The quest to pass the bill and to permanently establish The Freedmen’s Bureau pitted Congress - who sought to exercise its influence on behalf of freed blacks, against the antagonist efforts of President Andrew Johnson (Smith 1997, 301-302). President Johnson vetoed The Freedmen's Bureau bill on the grounds that it "was unconstitutional 
and it sought to do more for Negroes than had ever been done for whites” (Franklin 1947, 300). Congress’ attempt to over-ride the veto failed. On April 9, 1866 when a determined Congress over-rode President Johnson's veto of the Civil Rights bill, The Freedmen's Bureau was finally placed on solid ground. As Rogers Smith $(1997,290)$ describes, Congressional Reconstruction in 1867 was not as radical as had been anticipated, particularly in regards to land redistribution. It did however, provide some succor to freedmen. By 1870 The Freedmen’s Bureau was leasing small plots of land abandoned during the Civil War to freedmen throughout the South (Franklin 1947, 303).

In 1877 Rutherford B. Hays removed federal troops from the South in return for support from Democratic Southern Congressmen. Du Bois $(1935,692)$ argues that the removal of troops allowed planter-capitalists to control South Carolina and Louisianathus granting Southern landholders and capitalists complete control of disfranchised black labor. The removal of federal troops signaled the end of Reconstruction, and as a result progress in establishing independent farming for freedmen was severely hampered (Reynolds 2002, 3). Failed Reconstruction was a turn for the worse for black labor because without the federal government actively assisting freedmen to establish economic independence, their ability to purchase land and work as an independent farmer was abated (Hurt 1994, 167). Magdol $(1977,197)$ argues that Reconstruction failed freedmen in large part because proponents were unable to revolutionize landownership. To buttress this point, Marshall $(1971,57)$ and Higgs $(1977,78)$ assert that Congress' inability and unwillingness to implement a major land settlement program was a lost opportunity to establish freedmen as independent farmers. Acquiring land and purchasing the livestock and equipment to begin farming required financing and credit—and 
freedmen had neither. As a result, most black farmers were forced into sharecropping and tenant arrangements, which subjected them to excruciating poverty and perpetual debt (Hurt 1994, 167). ${ }^{2}$ Consequently, by the late 1880s, approximately $90 \%$ of all black farmers were forced into sharecropping (Gilbert and Eli 2000, 31).

Even though governmental action to assist freedmen was thwarted due to institutional political wrangling, black farmers sought to rise out of their proletarian status through the working of cooperation and collective action (Magdol 1977, 197). In 1877, a group of white farmers came together on a farm in Texas to form the first “Farmers Alliance” (Zinn 1997, 207). "By 1886, 100,000 farmers had joined in two thousand suballiances. They began to offer alternatives to the old system: join the Alliance and form cooperatives; buy things together and get lower prices. They began putting their cotton together and selling it cooperatively_-they called it bulking” (Zinn 1997, 207).

By the mid 1870s, black farmers came together in the South to form the Colored Farmers National Alliance Cooperative Union (CFNACU) (Reynolds, 2002). The CFNACU was a segregated branch of the Farmers Alliance, which comprised approximately one million members (Zinn 1997, 211). The movement by CFNACU also sought to establish greater self-sufficiency by developing strategies of operation on a cash basis, as opposed to the widely held crop-lien system. CFNACU worked to provide supplies and loans to help members purchase equipment and pay land mortgages

\footnotetext{
${ }^{2}$ Sharecroppers were farmers who worked in the field of the owner and were paid a "share" of the crop they harvested. Tenant farmers were farmers who paid an annual cash rent to the owner and kept the proceeds of whatever was harvested. Tenant arrangements were preferred because black farmers had more discretion over the number of hours worked within the day. (For further discussion see Charlene Gilbert and Quinn Eli. 2000. Homecoming, The Story of African American Farmers. Boston: Beacon Press)
} 
(Reynolds 2002, 5). ${ }^{3}$ As Zinn $(1997,210)$ explains, black and white Alliance farmers were in two different situations. Blacks were primarily field hands and hired laborers; while white Alliance members were farm owners. Therefore when the CFNACU declared a general cotton harvest strike in 1891 for a dollar a day wages for cotton pickers, Leonidas Polk, head of the Southern Alliance, denounced it as hurting the Alliance farmer who would have to pay that wage (Zinn 1997, 210). This type of activism increased divisiveness between the CFNACU and the Southern Alliance. The CFNACU movement was further weakened when it united with the Populist Party; which later dissolved after losses in the elections of 1892 and 1896 (Reynolds 2002, 6).

Other efforts to aid black agriculture came in 1890 in the form of agricultural education. Debra Reid (2003, 261) states, “it took nearly thirty years before the United States Department of Agriculture (USDA) responded to African American petitioners seeking access to public agricultural colleges and experiment stations and the right to participate in other USDA programs."4 In 1890, Congress passed the Second Morrill Act, which permitted states to establish separate institutions of higher education to African Americans seeking education in agriculture, trades, and household economy (Reid 2003, 261; McDowell 2001). However, 1890 institutions were only effective when provided federal funds for support were fairly and equitably distributed between them and the exclusively white 1862 institutions. Hurt $(1994,194)$ argues that 1890 institutions were demonstrably inadequate and incapable of assisting black farmers due to their lack of institutional funding.

\footnotetext{
${ }^{3}$ The resources, size, and operations of the CFNACU have not been documented-an historian is currently researching detailed information on the CFNACU.

${ }^{4}$ Debra Reid's assertion of 30 years is in reference to the passing of the first Morrill Act of 1862 and the creation of land grant institutions for white citizens.
} 
During the same year in 1890 with the passage of the Second Morrill Act, the USDA was also granted cabinet status from its establishment in1862. At its creation in 1862, the USDA was basically involved in collecting and disseminating information on new methods of increasing agrarian production (Brown, 2003). In providing insight into new forms of production, the USDA inherently embraced the importance of science and technical development as methods to bolster the farming sector. As such, Browne (2003, 134) explains that modern development, science, and new approaches to better production was primarily important to those who were crop diverse and committed to reorganizing to enter a market driven economy. Under such circumstances and given the current status of land ownership for black farmers, white landowners were in a far better position to take advantage of the services offered by the USDA.

Gilbert and Eli $(2000,149)$ argue that the USDA's affiliation with land grants and the funding of agricultural colleges/state universities inherently brought the agency into the political arena. Given that land ownership was an issue of racial tension in the South and the fact that most white congressmen in the House and Senate were inimical when it came to initiating and supporting policies intended to provide landownership to black farmers, the USDA became a vehicle for accommodating white profit producing farmers (Du Bois, 1935). Thus, when whites in Congress insisted that any bills related to landownership be worded in a way that would not benefit black farmers, the USDA expressed no objection — and from this point on the USDA remained an institutional participant in the gradual decline of black farmers (Gilbert and Eli 2000, 149). White landowners, the USDA, and southern congressmen had formed a cozy relationship that would exist for years to come. 
The early relationship that had emerged between the Agriculture Committees, the USDA, and the interests of large, white landowners was the early development of a “dominant” subsystem arrangement. Worsham $(1997,3)$ argues that members of select congressional committees, bureaucratic personnel, and interest groups affected by a policy in question, can form a dominant arrangement and consequently shape policy in manner that favors their interests. ${ }^{5}$ The relationship that was evolving between the USDA, large landowners, and southern congressional members of the Agricultural Committees was characteristic of “exclusionary politics.” McCool $(1998,560)$ contends that exclusionary politics emerge when subsystem participants can effectively and consistently exclude their opponents from active policymaking. Under such an arrangement, the subsystem enjoys unparalleled control and influence over the structure and future of a policy in question. Unfortunately, this early arrangement limited the possibilities that black farmers would achieve land ownership and the resources necessary to maintain it.

By January of 1914, factions developed in Congress when the issue of race emerged in the debate over the extension bill. Northern farm-state Republicans sought to secure language that would ensure fair distribution of the funds to black land-grant colleges; while southern Democrats resisted the inclusion of a racial fairness mandateparticularly southern Democrats insisted on the states' authority to decide the issue (Sanders 1999, 334). Southern Democrats proved victorious when Senator Ellison Smith (R-SC) arranged to have the provision given up in conference, thus leaving the bill's funds to be distributed as the state legislatures directed (Sanders 1999, 334). The

\footnotetext{
${ }^{5}$ Additional insight and discussions about subsystems is discussed in detail in Chapter 3.
} 
conference bill was later approved and signed by the President Woodrow Wilson in May of 1914 (Sanders 1999, 335). After 1914, the USDA's Extension Service, which now operated through state extension services, provided informal education on agriculture to rural residents. Unsuitably, African American farmers received minimal information and assistance due to underpaid, overworked extension agents segregated at 1890 institutions (Reid 2003, 262). Huffman (1981) suggests that the quantity and quality of farmers' extension service was a primary source for the differential productivity on black and white farms. Not only did black farmers have to contend with the paucities of extension service, but the emergence of the Great Depression only made matters worse.

\section{The New Deal And Its Soiled Agricultural Adjustment Administration}

The period of the late 1920s and 1930s was a difficult juncture in agriculture. The slow emergence of mechanization, economic depression, and the decline in major commodity prices proved problematic for many farmers, particularly for black farmers (Reynolds 2002, 8). As a result, many agriculture interests found themselves scrambling for assistance, but within the pandemonium for relief and influence, particular interests were accommodated while others became displaced losers.

The onset of the Great Depression in 1929 triggered an interventionist role of government in the realm of agriculture. President Franklin Delano Roosevelt sought to address the downturn in agriculture through the creation of the New Deal's Agricultural Adjustment Administration (AAA). The AAA did not seek to help the poorest of farmers such as sharecroppers and tenants, but it favored larger more affluent farmers (Zinn 1997, 
288, 285). ${ }^{6}$ A major way the AAA attempted to organize agriculture was through the utilization of its crop reduction program. Under the reduction program, farmers were provided cash benefits for plowing under a designated portion of their cotton, wheat, and grain crops and for slaughtering their hogs (Franklin1947, 523).

The AAA's crop reduction program was detrimental to black farmers in two profound ways. One, reducing the amount of crop harvested meant that sharecroppers and tenants were no longer as beneficial to the farm owner as they were prior to the depression—-thus the majority of black farmers were forced to move from one town to another in search of work (Reynolds 2002, 8; Hurt 1994, 297). Moreover, while owners’ cash benefits increased to thousands of dollars under the AAA, many of the grants intended for black farmers were misappropriated (Franklin 1947, 523). Many landlords took advantage of illiterate sharecroppers and tenants by simply keeping their checks and later removing them from their land (Franklin 1947, 523; Hurt 1994, 297).

The second detriment of the AAA's program involved the issue of farm size. The scant number of black farmers who had acquired land through efforts of the CFNACU, could not participate in the program because their land was not large enough to have a portion of it plowed under. Brown and Christy (1994) suggest that support payment policies were disadvantageous to small-scale farmers because having to set land aside would no longer allow such farmers to have a profitable unit. Ingolf Vogeler $(1984,84)$ argues that without an adequately sized farm, capitalism forces small-scale farmers out of business at the benefit of agriculturalists operating on a larger scale. In essence, black farmers received nothing more from the AAA other than hardship and disappointment.

\footnotetext{
${ }^{6}$ As defined by the USDA Agricultural Statistics Services, the cutoff between large and small farms is $\$ 250,000$ in gross annual sales. Farms that gross less than this figure are defined "small” farms, while those grossing more than this figure are defined as "large" farms.
} 
James C. Cobb $(1992,191)$ indicates that the complaints by black tenants concerning AAA abuses in the Mississippi Delta is a clear illustration of their disappointment and frustration.

Numerous official tenant complaints about AAA abuses either fell into a bureaucratic black hole or found their way back to county committees whose planter membership quickly saw to it that neither rental contracts nor federal assistance was available to those who had filed them. Such consequences were profound indeed in a region where more than 90 percent of the tenants were blacks whose meager incomes depended entirely on white employers and/or government relief.

As 1937 approached, African American farmers experienced a ray of hope. Moved by the plight of the agricultural poor, Secretary of Agriculture, Henry A. Wallace established and chaired a special committee on Farm Tenancy. Through his efforts, Congress passed the Bankhead Jones Farm Tenant Act of 1937 (Culver and Hyde 2000, 169-171). This Act authorized the government to provide long-term, low interest loans to tenant farmers for the purchase of land and farm equipment. Wallace reorganized the unsuccessful Resettlement Administration (RA) and created the Farm Security Administration (FSA) within the USDA to implement the Act (Brown 2003, 140). Franklin $(1947,524)$ explains that after 1942, appropriations to the FSA were drastically cut, and as a result aid to black farmers by the agency was quickly abbreviated. Following three years without funding, the FSA was closed in 1946 (Browne 2003, 141). Brown (2003) suggests congressional opposition was the fundamental reason for the demise of the FSA. Congress and select interests felt the FSA was not effectively and consistently serving farmers who were on the leading edge of modernization, 
development, and technological adoption. ${ }^{7}$ More importantly, "those who held these expectations also held prominent positions within the dominant and conservative agrarian development factions within Congress and the USDA, in the Extension Service, and as allied leaders of the Farm Bureau” (141). In part, the American Farm Bureau Federation (AFBF) used its entrenched local administrative network and vehemently campaigned for the abolition of the redistributive effort of the FSA. The AFBF's adversaries-The Grange and The Farmers’ Union railed against such action, but to no avail, their efforts proved unsuccessful (Sanders 1999, 417). ${ }^{8}$ Browne (2003) suggests the dominant subsystem arrangement that was developed against the FSA, allied Farmers Union, and urban liberal congressmen ultimately proved problematic for black farmers who longed for Congress’ attention in addressing their needs. Reminiscent of the relationship that had formed in the early 1890s - the FSA, congressional Agriculture Committees, and the AFBF had institutionally solidified their gatekeeping arrangement and were once again exercising exclusionary politics.

\section{Agricultural Policy (Post-New Deal) 1945-1960}

The decade of the 1940s and into the 1950s found farmers experiencing a wave of prosperity. Farmers were able to reap large profits from wartime prices; and as a result were able to utilize their profit to acquire more land, equipment, and pay off debts. The rise of more financially secure, federally protected farming in the mid-1950s resulted in

\footnotetext{
${ }^{7}$ Adell Brown and Ralph Christy. 1994. Structural Changes in U.S. Agriculture, Implications for Black Farmers. Review of Black Political Economy illustrate that large profit producing farms were indicative of those embraced by most conservative members of Congress.

${ }^{8}$ Although not as resourceful as the AFBF, The Grange and The Farmers' Union were at the time two relatively prominent groups that represented the interests of white, small family farmers. Considering that the FSA also provided assistance to such farmers, both groups favored the actions of the agency.
} 
significant changes in agriculture and agricultural policy. Hurt $(1994,327)$ suggests that mechanization along with the improvement of hybrid seeds and livestock helped boost agriculture productivity by $11 \%$. However, the use of science and technology significantly increased operating costs as well, which in turn kept farmers in a cost-price dilemma.

Farmers and influential agricultural interests such as the American Farm Bureau Federation, The National Farmer's Union (NFU), and The Grange all turned to the federal government for price support and marketing aid to help guarantee parity income with other American industries (Hurt 1994). ${ }^{9}$ The federal government answered the call to increase farm income by providing credit to "farmers who it judged had the best chance to succeed,” or the most economically viable farmers who were able to produce in high quantities (Hurt 1994, 327). The result was small farming entities struggling to survive in a world conducive to large-scale production units (Spitze, Deray, and West, 1980). Furthermore, the high cost of modern machinery and the fact that such machinery was not functional for small-scale farming, fundamentally limited the competitive position of small farmers - particularly African American farmers (Brown and Christy, 1994, 55).

Until the mid 1950s agricultural policy was largely based on the Agricultural Adjustment Act of 1938. The Act of 1938 emerged from a conference of farm lobby

\footnotetext{
${ }^{9}$ Price support was a price set by government above free-market level and maintained by governmental purchases of excess supply. For a discussion see Robert S. Pindyck and Daniel L. Rubinfeld. 2001. Microeconomics. New Jersey. Prentice Hall. pp 302-304. "Parity" was an index of the purchasing power of one unit of an agriculture commodity. It represented the price needed to give a bushel of corn or a pound of cotton. (For a discussion see Robert L. Tontz, Origin of the base period concept of parity: A significant value judgment in agriculture history,” Agricultural History, 32 (January 1958), pp. 3-13—sited from John Mark Hansen, Gaining Access Congress and the Farm Lobby, 1919-1981. 1991. pp. 78. Chicago: The University of Chicago Press
} 
leaders called by Secretary of Agriculture Henry A. Wallace-which was dominated by The Farm Bureau (Hansen 1991, 80). The primary goal of the Act was a mix of mandatory nonrecourse loans and tight production quotas. Hansen $(1991,82)$ explains that the nonrecourse loans and strict production quotas focused on five basic commodities - (1) cotton, (2) corn, (3) wheat, (4) tobacco, and (5) rice. The Act guaranteed U.S. Treasury payments and Commodity Credit Corporation (CCC) loans to farmers who maintained their quotas. As such, whenever commodity prices dropped below the value of their loans, it allowed growers to reclaim their loans by forfeiting their crops to the CCC (hence, for the government, they were "nonrecourse” loans) (Hansen 1991, 82). Large landowning farmers primarily benefited from the Act's provision because adhering to strict production quotas did not adversely impact their overall level of income. Moreover, modern equipment, and improvements in crop materials, enabled such farmers to achieve both higher levels of productivity and dramatic savings in production (Cobb 1992, 205).

The Agricultural Acts of 1949, 1954, and 1956, were designed to establish a flexible price support plan for basic commodities. Hansen (1991) suggests that The Farm Bureau's access to the Agriculture Committees was influential in the passage of each Act. The AFBF sought to solidify flexible price supports because it removed the federal government out of agriculture and favored a free market economy — which was preferred by most large-scale farmers. ${ }^{10}$ Even though the Farm Bureau had solidified access to the Agriculture Committees, various groups constantly worked to shape agricultural policy

\footnotetext{
${ }^{10}$ In utilizing flexible price supports large farmers could more readily adjust their output and income according to fluctuations in the market. Small farmers preferred and benefited from high price supports because it offset their limited farm capacity to produce in large volumes. (See Pyndyck and Rubinfeld, 2001 pp.302-304 for further insight into this discussion)
} 
according to their interests. Particularly, the National Farmers' Union pushed for government intervention by advocating high price supports. Contrary to the AFBF and the NFU, specialized commodity groups supported moderate agricultural prices and favored neither a laissez-faire nor interventionist government in agriculture (Hurt 1994, 352). In part, the dominant party in Congress influenced the opportunity for specified groups to shape agricultural policy. After World War II, Democratic-controlled congresses and Republican presidents readily disagreed over the direction of agricultural policy. Republican presidents and their congressional allies favored policy that entailed flexible price supports and the removal of government from the agricultural arena, while the Democratic camp embraced high price supports to accommodate small farms (Hurt 1994, 353). However for black farmers the issues of land ownership and agricultural credit, and farm income were most pressing, and unfortunately at the time such issues received little attention.

The Agriculture Act of 1956 adversely affected black and small farmers via the two part Soil Bank Program, which allowed the federal government to rent land from farmers to remove it from production. The Short-Term Acreage Reserve Program allowed participating farmers to receive federal payments for reducing their acreage of basic crops. Participating farmers were not allowed to plant other crops on the withdrawn acreage. Under the Conservation Reservation Program the government paid farmers to reduce their cultivated acreage, contingent upon placing the land in a longterm conservation program, thereby also removing it from production. Most acreage reduction programs required farmers to a leave a portion of their land idle. Farmers who exceeded their program acreage were ineligible for government support payments on any 
production of that crop (Kennedy and Viser 1990, 28). Again, black farmers were unable to take advantage of such programs because their limited farm size made it arduous to increase their income under the programs’ provisions.

\section{Agricultural Policy, 1960-1980: A Changing Political Environment}

By 1960 the stronghold of flexible price supports had subsided, and Congress had changed its approach in guiding agricultural policy (Orden 2002). In addition to repealing flexible price supports, Sheingate (2001) suggests that Congress embraced the idea that agricultural policy characteristic of voluntary provisions was a way to relieve tensions between political parties, producers, and various commodity users. The congressional stance on agricultural policy shifted due in large part to a change towards bipartisan politics, the interests of nonrural constituents that Congress sought to accommodate, and the prominence of commodity organizations in the representation of agricultural interests (Sheingate 2001; Hansen, 1991). Subsequently, the Agriculture Act of 1965 reflected the voluntary measures desired by Congress. Along with establishing price supports near world market levels, the 1965 Act also allowed for voluntary acreage controls for feed grains, wheat, and cotton (Hurt 1994, 355). These voluntary acreage measures allowed producers to set aside “additional” land for an extra payment. Sheingate (2001, 144) argues that voluntary programs aimed at individual commodities helped lessen partisan conflict during the development of agricultural policy.

Although partisan conflicts over agricultural policy decreased during this time, several allegations by black farmers claiming discrimination by local USDA offices began to surface (Gilbert and Eli 2000, 149). In response, Secretary of Agriculture 
Clifford Hardin sought to make public amends by issuing memorandum number. 1662, which required each USDA agency to implement Public Notification Plans (PNP). These PNPs required agencies to inform minorities of the availability of all USDA programs and to ensure that their participation in such programs were free of discrimination. ${ }^{11}$ And while it was promising for black farmers to recognize the secretary’s call for fairness, only time would tell whether the USDA would adhere to Hardin's requests.

As agricultural policy unfolded in the 1970s, the political environment in Congress changed due to the lessening of dominant subsystem politics (Sheingate 2001; Hurt 1994; Baumgartner and Jones, 1993; Hansen 1991; Browne 1988). Congressional reforms from 1971-1977 centralized authority within Congress, and thus weakened the autonomy and influence maintained by individual committees. Browne (1988) and Sheingate (2001) suggest that congressional reforms helped usher in numerous urban and suburban members of Congress and as a result, the structure of farm policy represented interests beyond the scope of farmers. As such, in 1973 Congress passed the Agriculture and Consumer Protection Act. A major provision of this legislation replaced the concept of price supports with deficiency payments in the event that commodity prices fell below a particular target price. Although the title of the new Act may indicate otherwise, consumer advocates remained on the sidelines during the passage of the bill. The collaborative efforts of the Senate Agriculture Committee and farm state Republican senator Milton Young (ND) were primarily responsible for bringing forth the bill (Hansen 1991, 193).

\footnotetext{
${ }^{11}$ Made available by James W. Locker EEO coordinator at Penn State College of Agricultural Sciences. Information documented in Penn State Cooperative Extension Civil Rights Resources, August 5, 1999; document number 109053 (old Penn Pages). Also available online http://www.cas.psu.edu/docs/
} 
As the 1980s emerged, the effects of a farm crisis adversely impacted the farming community. To address the slumping conditions in agriculture, President Ronald Reagan and Secretary of Agriculture John Block decreased price-support payments through the passage of the Agriculture and Food Act of 1981. This piece of legislation reduced agricultural spending and adjusted payments to $\$ 50,000$ per year for farmers who participated in government agricultural programs. It did not address the problem of overproduction, low prices, and high government costs — and consequently, farmers continued to experience hard times under the crisis. Congress responded to these issues with the Food Security Act (FSA) of 1985, which set maximum and minimum limits on participating farmers’ idled percentage of acreage base (Kennedy and Viser, 1990). In addition, payments-in-kind (PIK) certificates were another important aspect of the legislation. With the introduction of PIK certificates the USDA effectively obtained the right to issue currency (Thompson 1990, 87). Thompson $(1990,87)$ states that PIK certificates are “dollar denominated, payable to bearer, fully negotiable, and-better than cash in your pocket—backed by real goods.” In addition to the fact that PIKs typically traded well above par, farmers certainly appreciated their introduction during the crisis. Direct evidence that African American farmers benefited from PIKs is unsubstantiated, however, due to planting reductions induced by PIKs (Browne, 1988, 227) it is plausible to surmise that black and small-scale farmers did not benefit from PIK provisions.

\section{Agricultural policy, 1985-1996: Discrimination vs. Hope For Black Farmers}

The passage of the Food Security Act of 1985 also brought forth a special program for small farmers, known as Limited Resource Loans (LRL). Under the LRL, "twenty-five 
percent of all farm ownership and farm operating loans were targeted by the Farmers Home Administration (FmHA) as limited resource loans to be provided to low income farmers under special terms and at reduced interest rates” (Grim 1996, 328). Even though such loans were intended to address the needs of small farmers, a report from the Civil Rights Commission suggested that African American farmers did not significantly benefit from the LRL program during the 1980s, due to patterns of discrimination (U.S. Commission on Civil Rights, 1982). Notably, discrimination was rampant in local FmHA offices in the South because loan decisions were granted by county committees comprised primarily of local white farmers (Gilbert and Eli 2000, 135). To complicate matters, President Ronald Reagan cut the USDA budget in 1982 by eliminating its civil rights complaint division (Mittal and Powell 2000, 5). ${ }^{12}$ Grim (1996) suggests that the economic gap during this time widened between black farmers and their white counterparts, due largely to the discrimination they faced trying to obtain assistance and credit from agricultural agencies. Moreover, Grim (2002) suggests that black farmers experienced problems receiving disaster relief and capital due to government farm programs and policies being implemented in a discriminating fashion. Similar to the Agriculture and Food Act of 1981, the Food Security Act of 1985 also failed to solve the problem of overproduction and low prices.

Two years later in 1987, with the passage of the Agricultural Credit Act, additional attempts were made to address the needs of small American farmers. The Act was particularly beneficial to such farmers because it made additional FmHA (now the

\footnotetext{
${ }^{12}$ The USDA's civil rights complaint division was established after the passage of the Civil Rights Act of 1964. It consolidated its departmental function into a new office of Civil Rights in 1997.
} 
Farm Service Administration-FSA) loan funds available to small-scale farmers. This was pivotal because it provided small-scale farmers the opportunity to develop a plan to save their farms and operate profitably. Unfortunately, many African American farmers struggled to take advantage of this opportunity because as indicated, it was alleged the Farm Service Agency discriminated against black farmers by choosing not to process their loan applications.

Three years later in 1990, the passage of the Food, Agriculture, and Conservation and Trade Act (FACT), explicitly brought forth assistance to black farmers. Through the “Outreach and Assistance Program for Socially Disadvantage Farmers and Ranchers” under Title XXV of the Act, efforts were made to curtail the demise of black farmers by providing technical and educational assistance (Brown and Christy 1994, 56). A shift towards assisting black farmers occurred due to the success of minority policy entrepreneurs defining agricultural policy in the context of civil rights. ${ }^{13}$ Furthermore, the program also allowed land-grant colleges to establish training programs to assist small family farmers with financial matters such as simple accounting strategies and effective bookkeeping.

The Farmers Home Administration’s Social Disadvantaged Program (SDA) was established in 1990 to provide funds for minority farmers to purchase farmland, so as to “increase the number of socially disadvantaged applicants (Blacks, American Indian, Hispanics, and Asia or Pacific Islanders) acquiring FmHA’s farm ownership loans and purchasing inventory farmland” (Brown and Christy 1994, 56). Both programs of the Act were initiated by the collaborative efforts of various farm groups such as The Federation

\footnotetext{
${ }^{13}$ This shift and the actions of policy entrepreneurs will be detailed in Chapters Four and Five.
} 
of Southern Cooperatives, The Land Loss Prevention Project, and The Farmer's Legal Action Group as well as legislative entrepreneurs Congressmen Mike Espy (D-MI) and Senator Wyche Fowler (D-GA). However, McGraw and Taylor (1991) suggest that neither program has achieved the desired results due to poor implementation strategies and limited funding. Particularly, the FACT Act included an authorization of \$10 million for outreach and technical assistance, but unfortunately for the first three years after its passage, Congress failed to appropriate any money. Since this time, only one to three million dollars has been appropriated in most years (Sherrod, 2004).

1996 brought fundamental changes to agriculture with the Federal Agricultural Improvement and Reform Act (FAIR) and The Freedom to Farm Act. Under the FAIR Act the link between income support payments and farm prices were removed. In addition, this legislation authorized seven-year production flexibility contract payments that provided producers with fixed government payments independent of current farm prices and production (Gardner, 2002). This piece of legislation also softened the affect of the global market on support payments. In addition, The Freedom to Farm Act also made sweeping changes to federal farm programs. Under the Act traditional subsidy payments to farmers were replaced with a fixed but declining level of transition payments—36 billion over seven years (du Pont, 1996). In addition, the Act also terminated federal authority to hold farmland out of production. Allowing for greater planting flexibility, farmers could plant a mix of crops, excluding fruits and vegetables and still qualify for subsidy payments. However, at the end of seven years, unless Congress recommits to the Act, the old farm policies of land set-asides automatically come back into effect (du Pont, 1996). 
Many critics contend Freedom to Farm primarily accommodates large, corporate farms and agribusiness partnerships as opposed to small family farms because it does not explicitly provide provisions guaranteeing subsidy payments or a safety net to small production farmers (Lilliston and Richie, 2000). Notably, in the first three years of the Freedom Farm program, wealthy agribusiness partnerships and large farm corporations in Iowa reaped over half of the 2 billion in federal farm subsidies; while the other half of the funds were distributed out in smaller payments of typically less than $\$ 6,000$ to small family farmers (Ingersoll, 2000). Ralph Paige, Executive Director of the Federation of Southern Cooperatives, which represents the interests of black farmers, was asked in an interview about the impact of the Republican sponsored "Freedom to Farm Act.” Paige responded by saying:

The Freedom to Farm Act is I think devastating. It is nothing more than a welfare program that would pay large corporate farmers to grow fence-row to fence-row. It does not have a safety-net in this bill that would protect family farmers for the long-run. It has decreasing payments that will fade out in seven years. The small farmers who have small acreage and small allotments will be the ones who are hurt most because their payments will be very small and would fade out quickly. For instance the Peanut Program should not be tampered with because it does keep farmers on the land and many poor people in rural communities especially in Georgia, Alabama, and South Carolina derive a living from the Peanut Program N. Paget-Clarke (personal communication, February, 1996).

Clearly the Freedom to Farm Act poses many problems for small farmers, both black and white. To recapture aspects of the aforementioned discussion, table 2.1 summarizes the various influential Agricultural Acts pertinent to the study. 
Table 2.1: Summary of Relevant Agricultural Acts

\begin{tabular}{|c|c|c|c|}
\hline Act & Provisions & Benefits & Explanations \\
\hline $\begin{array}{l}\text { Agriculture } \\
\text { Adjustment Act } \\
\text { of } 1933 \text { (AAA) }\end{array}$ & $\begin{array}{l}\text { Awarded productions allotment; } \\
\text { Provided payments for crop } \\
\text { reduction }\end{array}$ & $\begin{array}{l}\text { Largest } \\
\text { landowners }\end{array}$ & $\begin{array}{l}\text { Farm Bureau lobby } \\
\text { successfully }\end{array}$ \\
\hline AAA 1938 & $\begin{array}{l}\text { Restricted production of crops; } \\
\text { paid farmers subsidies based on } \\
\text { parity }\end{array}$ & $\begin{array}{l}\text { Largest } \\
\text { landowners }\end{array}$ & $\begin{array}{l}\text { Farm Bureau lobby } \\
\text { successfully }\end{array}$ \\
\hline AAA 1949 & $\begin{array}{l}\text { Established mandatory } \\
\text { commodity support; and farm } \\
\text { income support }\end{array}$ & $\begin{array}{l}\text { Largest } \\
\text { landowners }\end{array}$ & $\begin{array}{l}\text { Farm Bureau dominates } \\
\text { access to House } \\
\text { Agriculture Committee }\end{array}$ \\
\hline AAA 1954 & $\begin{array}{l}\text { Maintained mandatory commodity } \\
\text { support; and farm income support }\end{array}$ & $\begin{array}{l}\text { Largest } \\
\text { landowners }\end{array}$ & $\begin{array}{l}\text { Farm Bureau lobby } \\
\text { successfully }\end{array}$ \\
\hline AAA 1956 & $\begin{array}{l}\text { Maintained mandatory commodity } \\
\text { support: and farm income support }\end{array}$ & $\begin{array}{l}\text { Largest } \\
\text { landowners }\end{array}$ & $\begin{array}{l}\text { Farm Bureau lobby } \\
\text { successfully }\end{array}$ \\
\hline $\begin{array}{l}\text { Food and } \\
\text { Agriculture Act of } \\
1965 \text { (FAA) }\end{array}$ & $\begin{array}{l}\text { Permitted voluntary acreage } \\
\text { control; provided economic } \\
\text { development program to fight } \\
\text { rural poverty }\end{array}$ & $\begin{array}{l}\text { Family farmers } \\
\text { of feed grain, } \\
\text { wheat, and cotton }\end{array}$ & $\begin{array}{l}\text { Commodity organizations } \\
\text { gain access to } \\
\text { congressional } \\
\text { deliberations; bipartisan } \\
\text { cooperation occurs } \\
\end{array}$ \\
\hline $\begin{array}{l}\text { Agriculture and } \\
\text { Consumer } \\
\text { Protection Act of } \\
1973 \text { (ACPA) } \\
\end{array}$ & $\begin{array}{l}\text { Farm income supplemented only } \\
\text { when commodity prices fell below } \\
\text { legislated “target prices;” food } \\
\text { stamp program extended }\end{array}$ & $\begin{array}{l}\text { Consumer } \\
\text { advocates }\end{array}$ & $\begin{array}{l}\text { Farm state Republican } \\
\text { (ND) Milton Young spurs } \\
\text { action of Senate } \\
\text { Agriculture Committee }\end{array}$ \\
\hline $\begin{array}{l}\text { Agriculture and } \\
\text { Food Act of } 1981 \\
\text { (AFA) }\end{array}$ & $\begin{array}{l}\text { Reduced agricultural spending } \\
\text { and limited payments to } \$ 50,000 \\
\text { per year to farmers who } \\
\text { participated in agricultural } \\
\text { programs; expanded commodity } \\
\text { donations abroad }\end{array}$ & Farm Bureau & $\begin{array}{l}\text { Commodity experts lobby } \\
\text { successfully; President } \\
\text { Reagan and John Block } \\
\text { influence Congress to } \\
\text { decrease price-support } \\
\text { payments }\end{array}$ \\
\hline $\begin{array}{l}\text { Food Security Act } \\
\text { of } 1985 \text { (FSA) }\end{array}$ & $\begin{array}{l}\text { Sought to maintain farm income } \\
\text { while reducing costs; provided for } \\
\text { acreage reduction if agricultural } \\
\text { supplies became excessive }\end{array}$ & $\begin{array}{l}\text { Commodity } \\
\text { groups }\end{array}$ & $\begin{array}{l}\text { Commodity experts lobby } \\
\text { successfully }\end{array}$ \\
\hline $\begin{array}{l}\text { Agricultural Credit } \\
\text { Act of } 1987 \text { (ACA) }\end{array}$ & $\begin{array}{l}\text { Introduced new provisions of } \\
\text { FCA Act of 1971; established new } \\
\text { borrower rights and procedures } \\
\text { for restructuring of loans }\end{array}$ & Family farmers & $\begin{array}{l}\text { Small interested farming } \\
\text { groups lobby successfully }\end{array}$ \\
\hline $\begin{array}{l}\text { Food, Agriculture, } \\
\text { Conservation, and } \\
\text { Trade Act of } 1990 \\
\text { (FACT) }\end{array}$ & $\begin{array}{l}\text { Continued to provide loan rates } \\
\text { linked to market prices; } \\
\text { authorized price supports based on } \\
\text { target prices; increased } \\
\text { environmental regulations; } \\
\text { provided programs for African } \\
\text { American farmers } \\
\end{array}$ & $\begin{array}{l}\text { Commodity } \\
\text { groups; small } \\
\text { family farmers, } \\
\text { and black } \\
\text { farmers }\end{array}$ & $\begin{array}{l}\text { Minority farm groups, } \\
\text { policy entrepreneurs and } \\
\text { commodity experts lobby } \\
\text { successfully }\end{array}$ \\
\hline $\begin{array}{l}\text { Federal } \\
\text { Agriculture, } \\
\text { Improvement and } \\
\text { Reform Act of } \\
1996 \text { (FAIR) } \\
\end{array}$ & $\begin{array}{l}\text { Removed link between income } \\
\text { support payments and farm prices; } \\
\text { authorized 7-year production } \\
\text { flexibility contract payments to } \\
\text { participating producers }\end{array}$ & $\begin{array}{l}\text { Commodity } \\
\text { groups }\end{array}$ & $\begin{array}{l}\text { Commodity experts lobby } \\
\text { successfully }\end{array}$ \\
\hline $\begin{array}{l}\text { Freedom to Farm } \\
\text { Act of } 1996\end{array}$ & $\begin{array}{l}\text { Provided greater planting } \\
\text { flexibility, while increasing } \\
\text { subsidy payments }\end{array}$ & $\begin{array}{l}\text { Large farming; } \\
\text { agribusiness } \\
\text { partnerships }\end{array}$ & $\begin{array}{l}\text { Agribusiness farm } \\
\text { organizations lobby } \\
\text { successfully }\end{array}$ \\
\hline
\end{tabular}




\section{Conclusion}

Aside from loan and educational/technical assistance programs, the major component of post New-Deal agricultural policy has been a mix of price support and income policies executed through commodity programs. The majority of these programs have included supply control through acreage restrictions, long-term land retirement, price supports for direct purchases of commodities and the use of non-recourse price loans along with PIK certificates (Gardner 2002). While large-scale farmers were adjusting and benefiting from such policies and programs, black farmers were gradually disappearing while battling the pernicious effects of discrimination.

Furthermore, black farmers have consistently been on the outside looking in when seeking to influence the agenda of agricultural policy. Browne (1988) suggests that agriculture as a policy arena is so large and diversely structured that it inherently affects a multitude of interests. Thus, some interests exercise disproportionate influence, thereby limiting the opportunity for others to exert any pressure at all (Brown 1998, 5). With this in mind - the influences and structure of post-New Deal agricultural policy have precluded African American farmers from acquiring the income, credit and relief needed to not only prosper as independent farmers, but to maintain their subsistence. Before mapping the agricultural agenda and documenting the displaced interests of black farmers, the next chapter provides the groundwork for the remaining analysis by describing the theories and dynamics of agenda setting. 


\title{
3
}

\section{Agenda Setting and Issue Definition: Disrupting Policy Equilibria}

\author{
"The key is to understand why certain issues receive \\ governmental attention and others seemingly of equal \\ merit are ignored or bypassed by the decisions-makers at \\ all levels of government." \\ - Roger Cobb and Charles Elder (1972, 63)
}

\section{Theories of Agenda Setting and Government Policy}

The multiple relationships that emerge during agenda setting explain how an issue is defined and why a particular issue may not achieve agenda status. In order for a problem to be given institutional priority, it must first be transformed into an issue that Congress has agreed to address. Scholars of public policy understand the importance of such a distinction because problems placed on the systemic agenda do not carry the same level of prominence as those placed on the institutional agenda. This is because most problems on the systemic agenda have yet to gain the active attention of policymakers.

Cobb and Elder $(1983,83)$ state the systemic agenda "consists of all issues that are commonly perceived by members of the political community as meriting public attention and as involving matters within the legitimate jurisdiction of existing governmental authority.” In part, the systemic agenda is a discussion agenda in which most items on it will be general and abstract rather than specific and comprehensive (Anderson 1997, 99). In comparison, the institutional agenda is much more substantial. The institutional agenda is essentially an action agenda in which discussion items are 
more concrete and specified. Specifically, those items placed on this agenda have in essence gained enough support to be converted from a problem into an issue. Eyestone (1978) describes a problem as some state of affairs that injures or unfairly affects a particular sector of society. He contends that issues are the fuel of politics because they provide the energy for the day-to-day business of government (Eyestone 1978, 1). Thus, Cobb and Elder $(1983,32)$ argue that an issue is a "conflict between two or more identifiable groups over procedural or substantive matters relating to the distribution of positions or resources.”

Ripley (1985, 106-107) highlights a continuum of options that government officials can take in placing an individual item on the governmental agenda. Each of these particular options are important because they illustrate how institutional actors can either take a passive or an active role in defining a particular agenda item. In addition, highlighting these options reveal how certain values and ideologies are bolstered while others are ignored. Eyestone $(1978,5)$ asserts that if one group builds a range of contacts within government, and another group is unable to do so, the lesser group will have a more difficult time achieving its policy pursuits.

The first option coined "Let it happen," describes how government takes a passive role in agenda setting. In essence, government maintains points of access and communication so that groups can place pressure on relevant institutional leaders. Under this option interest groups seek to heighten public awareness and lobby government officials to get their concerns placed on the institutional agenda. This was illustrated during the 1960s when various grassroots organizations attracted considerable 
attention to a number of environmental problems in the United States (Adolino and Blake 2001, 12).

The option of “Encourage it to happen," illustrates how government aids groups in defining, prioritizing, and articulating their problems. Specifically, this particular option seeks to equip individuals to participate in the definition of problems.

The primary purpose is not to explicitly identify and define problems for those involved, rather it is to equalize the resources so that the process does not overtly favor the haves over the have nots. Eyestone (1978) suggests such resources are beneficial because organized interests (particularly those with minimal resources) are in turn able to establish their "professional” group activities, and thus further group endeavors.

The third option, "Make it happen,” emphasizes those instances in which government actors play an “active” role in setting goals and defining problems. As Randall Ripley states, "policy makers do not wait for the system to work; they direct its operations by establishing problem-defining and priority-setting mechanisms within government” (107). For example, the Clinton administration’s failed attempt for sweeping health policy reform in the early 1990s is an illustration of such action (Adolino and Blake 2001, 13).

“Don’t let it happen,” involves those instances in which government actors choose to restrict and close channels of access and communication. From this perspective, institutions function along side groups and participants who are seeking to limit or impede particular problems from gaining institutional attention. Anderson (1997, 106) notes this was apparent during the 1950s in the South when white activists succeeded in stifling minority demands for equal rights. In sum, each of the 
aforementioned options offers a different explanation of the role of government in agenda setting. Thus, agenda setting is the study of social stability and social change as it relates to groups and or governmental institutions (Dearing and Rogers 1996, 2). The following section seeks to elucidate this process by first examining the bottom-up approach to the study of agenda setting.

\section{A Bottom-Up Perspective}

Most studies that focus on the dynamics of agenda setting tend to take either a "bottomup” or a “top-down” approach. Many scholars (Hasan and Simmons, 1989; Hofrenning, 1989; Eyestone, 1978; Cobb and Elder, 1972; Down, 1972) regard a bottom-up approach as pluralist; therefore emphasis is placed on the role of the public and interest groups in developing the political agenda (Studlar 1990, 274). A bottom-up approach to agenda setting centers on the process by which issues begin in the public realm and rise onto the governmental agenda through circumstances of public opinion, social movements/influences, and or interest group activity. For example, Stimson (1999) suggests that the electorate responds to excesses on a left-right continuum and as a result, drives change at the elite level. As such, policy mood or the public’s underlying sentiment towards a particular issue drives policy.

Additional studies (Grossback, 2000; Stimson, Makuen \& Erikson, 1995) highlight the influence of public opinion, however they place greater emphasis on the existence of representation-representation in the form of politicos representing his or her constituents. Through the use of survey opinion polls such studies contend that when policy drifts away from the public's demands, elections can serve as a control mechanism 
to ensure the public’s policy preferences are represented. These particular studies are important because they illustrate how and why public sentiment may or may not be consistent with the decisions made by policymakers. Furthermore, these studies also reinforce the observations by Baumgartner and Jones (1993) who express how popular enthusiasm surrounding a given issue provides policymakers the conditions to create new institutions to support or even oppose particular policy programs.

Equally important, studies that point to social movements and social influences are also beneficial in understanding agenda setting. Chong, (1991) illustrates that largescale political activism or "public spirited collective action," such as that on the environment or civil rights have such a strong ideological element that it can push a problem from the grounds of the public to the government's door. As Chong describes through his supply-and-demand model, successful forms of collective action must include (1) steadfast leadership (2) political institutions (such as Congress) that are or have become willing to institute change and reform and (3) activists who have joined the movement must exceed the strength of opposing forces (164). Chong states that in order for proponents of change to achieve their goal, they must develop and maintain a movement that embodies a combination of disruption, pressure, and moral persuasion, which seeks to force local authorities and the federal government to adhere to its demands (142). Thus as Chong (1991) suggests, interest group activity is consequential because it has the ability to impel government to pay attention to issues that otherwise would have been displaced.

Interest groups and the relationship they establish with government institutions also contribute to influencing the agenda (Milakovich and Gordon, 2001; Anderson, 
1997; Kingdon, 1995). Baumgartner and Jones, (1993) and Worsham (1998) recognize how the monopolistic goals of interest group politics influence issue definition and the institutional agenda. Their research helps to highlight how the scope of conflict, change in issue image, and the movement of an issue from one venue to another can disrupt policy equilibria. In addition, the institutional arrangement of policy images and policy venues are equally important in relation to interest groups and their affect on the agenda because they illustrate the dynamics and conflict associated with various policies and why they may not gain agenda status (Baumgartner and Jones, 1993). This contention confirms the argument by Dearing and Rogers $(1996,2)$ who assert that agenda setting offers an explanation for why certain issues are addressed through policy actions while other issues are ignored.

Equally important, the bottom-up or pluralist approach to agenda setting not only involves public discourse, social movements/influences, and interest group politics, but it also involves the media. Scholars emphasize this point by highlighting the influence that the media has on framing the public's policy preferences and political participation (Kellstedt, 2000; Kernell 1993; Traugott, 1992). Iyengar and Kinder (1987) assert that the media powerfully influences which problems citizens regard as the nation's most serious, arguing that issues such as unemployment, energy shortages, and overall economic instability become high priority for public policy only if such issues become a primary news item for the networks. However, news coverage does not have to first filter through the public; rather it can directly influence policy elites. Cook et al (1983) take up this endeavor by examining the impact of the media on the general public, policy makers, interest group leaders, and public policy. Using an experimental design constructed 
around a single media event, the authors conclude that the media influenced views about issue importance among the general public and government policy makers. The authors suggest subsequent policy changes did not result from a change in public opinion, but rather from collaboration between journalists and government staff members (32). Overall, research that has focused on the media has been relatively valuable to the pluralistic approach to agenda setting, illustrating how the media can serve as a catalyst and a tool to shape the systemic and governmental agenda. Now that I have provided a basic understanding of the bottom-up approach of agenda setting, and I will now explore the dynamics inherent from the top-down perspective.

\section{A Top-Down Perspective}

Agenda setting from a top-down approach view the major initiatives deriving from government officials and policy communities (Kingdon, 1995; Studlar, 1990; Durant and Diehl, 1989; Nelson, 1984; Walker, 1977). This approach emphasizes how government actors and structures generate and or influence items on the institutional agenda without the issue moving from the public, onto the formal agenda. For example, the broad power of Congress to revise a current statute and fund or cut appropriations is quite influential on the agenda setting process (Anderson, 1997). The internal structure and jurisdictional struggles within Congress illustrates its direct influence on defining and bolstering particular issues. Jurisdictional battles within Congress are influential to the governmental agenda because such battles serve as a precursor to the success or failure of a particular policy issue (Lees 1967, 6). Baumgartner and Jones (1993) buttress this point 
by suggesting that the effect of different committees and subcommittees claiming jurisdiction over a particular issue lead to significant policy changes.

For example, Gandy (1982) describes how in the House during January of 1970, responsibility for education was divided among three subcommittees, and their chairs frequently struggled over control of how best to improve educational learning. Committee chair John Brademas (D-IN) sought to improve education through the utilization of instructional technology, while Edith Green (R-OR) felt states should have the discretion to decide the appropriate method. The jurisdictional battle came to a close when Green's subcommittee effectively investigated the shortcomings of the Office of Education, and as a result states were granted control of Title III education programs. The competition between Brademas and Green is pertinent to agenda setting because it illustrates the institutional struggle involved in defining and addressing a particular issue, and how doing so can beseech various interests at different levels of government.

In addition, King $(1997,16)$ argues that a "turf war" decided who sat at the table crafting the landmark Civil Rights Act of 1964. King contends that if the bill was not strategically written to award jurisdiction in the Senate to the Commerce Committee and the Judiciary Committee in the House, the Civil Rights Act would have died in the hands of Southerners on hostile committees. Thus, as Baumgartner and Jones (1993) argue, having a supportive committee in Congress is beneficial as long as the committee does not lose its jurisdiction. However, the broad powers and effects of Congress may not always constitute a top-down occurrence of agenda setting. Browne (1988) and Mayhew (1974) emphasize that congressional action is not solely the result of policy entrepreneuralism; but a desire to secure and adhere to constituents for reelection. From 
this perspective congressional activity may indicate a bottom-up approach to agenda setting as well.

Baumgartner and Jones (1993) assert that hearings are important to committees and subcommittees because not only do they signal the importance of an issue, but they can serve as a fact finding exercise beneficial in controlling the agenda and claiming new ground. For instance, Gandy (1982) indicates that the Joint Economic Committee organized hearings in 1966 merely in hopes of collecting information about the status of the education market. Furthermore, Talbert, Jones, and Baumgartner (1995) explore the importance of congressional hearings by focusing on four issue areas: pesticides, smoking, drug abuse, and civilian nuclear power. Through the utilization of 3,000 congressional hearings and witnesses who appeared at the hearings, the authors conclude that both legislative and nonlegislative hearings are subject to jurisdictional change over time. More importantly, nonlegislative hearings are found to be an integral part of the process "through which issues are raised, redefined, and put on the table for serious consideration” (400). In sum, the ability of Congress to set the agenda is not only conditioned by its broad statutory powers but also by its pervasive jurisdictional struggles.

Not only is Congress important to agenda setting, but the institutional actions of the president are also influential (Kernell, 1993; Neustadt, 1990). Baumgartner and Jones (1993) state "no other single actor can focus attention as clearly, or change the motivations of such a great number of other actors, as the president” (241). Specifically, the authors illustrate in the case of drug policy and urban affairs, how the president pushed these particular issues high onto the agenda. As Bosso $(1987,261)$ states, the 
president has the ability to serve as the political system's thermostat, capable of heating up or cooling down the politics of any single issue. Paul Light (1999) suggests that a president with strong external resources such as party support in Congress, public approval, a sizeable electoral margin, and patronage has the ability to influence the agenda setting process. Thus, the institutional relationship between the administration and Congress is pivotal in the president affecting the agenda setting process (Light 1999, 46). Hence, once the president gains congressional support the ability to affect the agenda is greatly strengthened. For instance, President Lyndon Johnson's declaration of a War on Poverty did a great deal to influence congressional attitudes toward antipoverty programs (Eyestone 1978, 91).

In addition to the institutional actions of the president, scholars argue that the Court is not only an institution that adjudicates cases but it is also an institution that makes political decisions, which in turn can bring attention to a particular policy issue or redefine an issue currently on the congressional agenda (Flemming et al 1997; McGuire and Palmer, 1996; Perry, 1991). Take for example, the issue of abortion. When the Supreme Court ruled on Roe V. Wade in January 1973 that states could not interfere with the decisions made by a woman and her doctor to have an abortion in the first trimester of pregnancy, Congress introduced several bills to amend the Constitution to extend constitutional rights to unborn children (Eyestone 1978, 112). Such an occurrence confirms Baumgartner and Jones' (1993) contention that decisions by the Court should be considered when understanding how policy issues emerge and change over time. In part, decisions rendered by the Court—particularly the Supreme Court can cause a shift in the system-wide attention and image to underlying policy issues (Flemming et al, 1997). In 
particular, Baumgartner and Jones (1993) and Flemming, et al (1997) argue that the Court's actions can direct attention to particular policies and or problems. As a result, certain cases heard by the Court can spur interest group activity to oppose or favor the issue it is deciding on, and in turn can lead the Court to act accordingly.

To illustrate this point, Calderia and Wright $(1998,1111,1123)$ argue the presence of amici curiae during case selection communicates to the Supreme Court information about the constellation of forces at play in the litigation, who is at risk, and the number and variety of interests regarding the litigation as important. The authors conclude that one or more amicus curiae briefs advocating or opposing certiorari increases the likelihood of the Court to grant certiorari (1122). Thus, the authors’ research is valuable to our understanding of agenda setting because it illustrates how organized interests can effectively influence which cases are placed on the Court's agenda, and how the Court may ultimately decide those cases. From this perspective the Court is a representative institution whose political decisions are not formed in a vacuum (Calderia and Wright, 1998). Therefore as Perry $(1991,6)$ argues, these are the political decisions that can influence and set the agenda for other political institutions for years to come. To further understand the dynamics involved in agenda setting, the following section describes the importance and influences involved in how an issue is defined on the agenda.

\section{Agenda Status and Issue Definition}

As Kelly Tzoumis $(2001,5)$ asserts, a policy often reaches Congressional attention because it has been framed or defined in a fashion that warrants governmental action. 
Baumgartner and Jones (1993) indicate how a policy is framed is important because it determines the players and interests that will be involved in the issue. Schattschneider (1960) argues that policy losers strive to broaden the scope of the conflict in hopes of persuading nonparticipants into understanding the issue from their perspective. Thus, expanding the scope is significant because it is instrumental in determining how the issue is defined, and consequently which policy is implemented. Tzoumis $(2001,5)$ asserts that if an issue is defined in a manner in which government is willing to address, then it will have a greater propensity of capturing congressional attention.

According to Eyestone $(1978,175)$, agenda status is primarily achieved only with regard to endemic issues_ — “public problems that extend over a period of years and generate incremental solutions.” Eyestone (1978) suggests that Congress is consequential to the status of an issue because it is this institution that groups seek to access in order to have their problem addressed by policymakers. Kingdon $(1995,199)$ indicates groups who are able to gain access are far more likely to bolster their issues on the agenda and block consideration of proposals they do not prefer. Furthermore, such groups are more likely to define the image of the issue according to their interests (Baumgartner and Jones 1993). Take for example the issue of biotechnology. Christopher Plein (1991) points out that the biotechnology industry was able to dispel fears concerning techniques to modify life forms for research and commercial uses by consistently portraying biotechnology in a positive image beneficial to society. This was partly accomplished by the industry's ability to line up supporters and casting aspersions on opponents.

Considering the notion of policy images, Baumgartner and Jones $(1993,25)$ argue that how a policy issue is discussed or defined has the propensity to attract interests that 
were previously uninvolved in the issue. For instance, Derthick (1979) describes how policymaking for Social Security was relatively consensual and stable until the 1970s when it faced financial problems. Derthick points out that once Social Security was discussed as a financial burden detrimental to the economy, participants from both private and public sectors were galvanized. For example, the Treasury Department, which had not been involved in social security policymaking for nearly thirty years, suddenly became interested and commissioned an independent actuarial audit to evaluate the overall cost of the system and its financial condition (1979, 388). Likewise, Congress also expressed concerned with the financial status of Social Security when the Finance Committee conducted an independent analysis, which concluded that the financial condition of the system was in disarray, and that major steps were needed to restore the financial health of the Old Age Survivors Disability Insurance Program (OASDIP). As Derthick (1979) illustrates, the negative financial image of Social Security that emerged during the 1970s not only shaped the discussions about the system, but was also the impetus for the emergence of additional interests.

In many instances once an issue is transformed or becomes galvanized and the number of participants increases, a shift in venue is more likely to occur as well (Baumgartner and Jones 1991, 1047). Baumgartner and Jones (1993, 31) state that “policy venues can be monopolistic or shared, that is, a single issue may simultaneously be subject to the jurisdiction of several institutions, or may be within the domain only of one set of institutions.” In many instances when the venue of a policy changes, those participants who previously had minimal influence may find themselves with greater power. 
As a brief illustration of how a change in issue definition and policy venue reinforce themselves, and how the minority can become the majority, Baumgartner and Jones (1991, 1048) provided an interesting example of an environmental group, which is consistently on the losing end of regulatory decisions made in the executive branch of the federal government. The authors postulate that if this displaced environmental group carries their issue to an uninvolved group in Congress, there is the possibility that a more favorable hearing in this particular jurisdiction will be afforded to them. Assuming this is the case, Congress may in turn pass legislation-allowing supporters access to the courts or in the regulatory process. As a result, environmentalists are also provided with additional influence in venues that had previously been inaccessible. Furthermore, the laws passed by Congress may change or redevelop the image of the issue, which can make for shared policy jurisdiction as well as expand the scope of conflict.

Oftentimes, participants who wage a subsystem can mold or define an issue in a manner consistent with its interests. Milakovich and Gordon (2001, 89) simplistically define a subsystem as "a political alliance uniting members of an administrative agency, a congressional committee or subcommittee, and an interest group with shared values and preferences in the same substantive area of policy making.” Such an institutional arrangement can prohibit an array of interests from becoming involved in the policy making process, thus allowing the subsystem to define the issue accordingly, and in most cases at the expense of those formerly excluded. "Subsystems then, are, a means of getting around the seeming inability of groups to effect closure on decisions that affect large numbers of interests” (Worsham 2004, 4). Worsham $(1998,486)$ argues that a 
"subsystem's ability to maintain policy making autonomy is not absolute; but rather it varies across time and policy area.”

Worsham (1998) illustrates that subsystem politics may assume any of three forms---dominate, transitory, or competing coalitions. Dominate coalitions benefit select interests as opposed to the public interest. Under such an arrangement, a particular committee or subcommittee is able to establish and control formidable jurisdiction in a particular policy area. Transitory coalitions emerge when "latent interests of some members of a dominant coalition supersede the interests they share in common with other members of the dominant coalition” (Worsham1998, 488). In essence, transitory coalitions bargain and compromise over the distribution of benefits and costs linked with a particular policy.

Competitive coalitions surface when a dominant coalition is openly challenged by a new coalition. In some instances this may occur when transitory coalitions engage in prolonged conflict, in which formerly excluded minority interests are able to effectively compete over the benefits of a particular policy. Likewise, the development of competitive coalitions can lead to a change in the image of an issue, which may cause a traditionally dominant coalition to collapse. For example, Baumgartner and Jones (1993) describe how nuclear power during the 1940s and 1950s was controlled by a powerful monopoly or a dominant coalition. However, in the 1960s and 1970s, the image of nuclear power changed from being uncontroversial and enthusiastic to that of perceived risk and danger. Once the image of the issue changed, a shift in venue followed, and as a result the strong monopoly in Congress and industry were consequently destroyed. Such an illustration indicates that subsystem autonomy is never permanent through time, but 
rather, autonomy is contingent upon the variant of subsystem politics at play (Worsham, 1998). To illustrate how the aforementioned perspectives and insights to agenda setting are conceptualized throughout the remainder of this research, the following section highlights the theoretical aim underlying the analysis.

\section{Theoretical Aim}

The theoretical aim of this study seeks to examine the institutional actions of Congress from a systems perspective as characterized by subsystem politics (i.e. meso-level analysis) and punctuating events. The system perspective defines politics and government as a conceptualized system of "inputs, throughputs and outputs functioning in an environment that provided the energy required by the system” (Peters 1998, 112). Peters $(1998,112)$ indicates that the "energy” required by the system includes factors such as the demands and supports from interest groups and individuals, and the changes/events that occur within and or outside the institutional workings of the system. The outputs of the system are policies, with a feedback loop reflecting responses to those policies.

Considering punctuating events can bring forth institutional change (see Baumgartner and Jones, 1993) meso-level analysis becomes all the more relevant, because attention is then placed on the functioning of specific institutions and interests, and the processes of constructing public policy. In this case, the primary institution of concern is Congress-specifically congressional committees. Baumgartner and Jones (1993) suggest if the activity by congressional committees consistently fails to represent a particular group of interests, the assumption holds that certain policy problems in relation 
to that group may be displaced or defined in an antagonistic fashion. Thus, the study assumes that although congressional Agricultural Committees may have direct influence over the agricultural agenda, events and inputs from the environment can influence their agenda setting pursuits and activity. Hence, the stimuli of punctuating events and the actions of other institutional actors and or groups can reinforce or counterbalance the political underpinnings involved in the agenda setting process.

In general, the theory postulates Agricultural Committees may serve as the institutional anchor for subsystem arrangement and policy monopoly, but punctuating events can and do alter the equilibria established by such an arrangement. Moreover, not only can subsystem equilibria be disrupted, but punctuating events can and do alter policy outputs as well. Thus, I expect to find evidence that shocks to the system and or the actions of policy entrepreneurs will influence the agenda setting of agricultural support policy. On this note, Baumgartner and Jones $(2002,11)$ contend that most system models of congressional behavior generally illustrate occurrences of negative feedback. With this in mind, the next two chapters seek to illustrate whether this analysis is characteristic of such feedback. 


\section{4}

\section{Tracking Agenda Status}

"Bill introduction and committee referral are important aspects of agenda setting that no subsystem can ignore if it is to maintain a policy monopoly."

- Jeff Worsham (1998, 494)

In the preceding chapters I discussed the troubled journey of African American farmers, and how the evolution of pertinent agricultural legislation failed to address and in effect exacerbated many of the problems/struggles black farmers faced. Due to the norms, culture, and political relationships formed, black farmers struggled to find a seat at the table of agenda setting. When the Farm Security Administration (FSA) was meeting their needs, the dominant subsystem arrangement between southern congressional members of the Agriculture Committees, the USDA and the interests of large - white landowners (i.e. AFBF) put an end to such accommodation.

This chapter seeks to understand this struggle by focusing on bill introductions as the first of two ways in which I explore how Congress governs the agenda of agricultural support policy over the post-war era. As Dearing and Rogers $(1996,1)$ argue, agenda setting is an ongoing competition among issue proponents to gain the attention of policy elites. Thus, bill introductions are useful in understanding this process because they serve as an important indicator of congressional interest in a particular policy area (Worsham, 2004; Wilkerson, Feeley, Schiereck and Sue, 1999). Moreover, not only do introductions indicate that an issue has made it onto the formal agenda, but its referral illustrates committee jurisdiction, underlying competition, and possible attempts of policy coupling. 
Particularly, the purpose of this chapter is three-fold. First, I seek to explore the formal agenda by examining the ebb and flow of bill introductions in both chambers over the post-war period in the policy areas of civil rights and agriculture. This cross comparison is not intended to illustrate a systematic relationship, but rather a snapshot of the overall level of activity and the instances where introductions (i.e. activity) increase in both policy areas. Second, I examine the issue composition of the introductions. In doing so, I am able to decipher the topics that receive the most attention in both policy areas - thus serving as a conduit to potential policy coupling. Third, I examine the referral of bill introductions-paying special attention to those that exhibit policy coupling. The analysis of bill referrals is important because Baumgartner and Jones (1993) argue they highlight the dynamics of policy jurisdiction. Furthermore, examining referrals seeks to illustrate not only committee competition and policy monopoly, but also whether the introduction of policy coupling escapes referral to a particular committee due to the issue framing of policy entrepreneurs.

\section{Data Collection}

As with most agenda studies, the postwar period is commonly used as the starting point for initiating data trends. The dynamics of federal agricultural policy after the 1940s, and the effects of pertinent focusing events, qualifies the postwar period as the ideal time frame for analysis. The time span of analysis for this study begins in 1940 and ends in 1998, providing over fifty years of examination concerning the agenda of agricultural support policy. The index volumes of the Congressional Record were utilized to assess 
bill introduction activity in both chambers from 1940-1998 in each policy area—civil rights and agriculture.

The Congressional Record identifies the sponsors of the legislation, along with the committees, where the bills are referred, the topic of legislation, whether it is reported from committee, subject to amendment, passed in the chamber of origin, and its lifespan in the other chamber. The search items used to track civil rights include: civil rights, African-Americans, black Americans, colored people, negro/negroes, race relations, racial discrimination, racial segregation, and any other "see also" indicated by the index. The search terms used for agriculture focus on topics of concern to African-American farmers which included: crop diversification, cotton, farm loans, price supports, soil conservation, tenant farmers, sharecroppers, relief programs, and any references to the USDA handling of any of the previous terms, as well as legislation dealing with the composition of county agricultural committees and or agents. ${ }^{14}$

The utilization of bill titles was employed to discern the topics under each policy arena. This method was a straightforward approach in the sense that anytime a bill title highlighted a particular topic it was then coded accordingly. For example, under the policy area of civil rights I would code a title "to prohibit discrimination within employment” as an employment topic, while under the policy area of agriculture I would code a bill title "to extend price support programs” as a price support topic, and so forth. The notion of policy coupling occurs when either policy area intersects with the other.

\footnotetext{
${ }^{14}$ Several sources were consulted to compose the list of search items, including two studies conducted by the US Commission on Civil Rights that detailed the plight of African American farmers. U.S. Commission on Civil Rights. (1965). Equal Opportunity in Farm Programs: An Appraisal of Services Rendered by Agencies of the United States Department of Agriculture. Washington, D.C.: U.S. GPO. U.S. Commission on Civil Rights. (1982). The Decline of Black Farming in America: A Report of the United States Commission on Civil Rights. Washington, D.C.: GPO.
} 
For instance, a bill title "to prohibit discrimination within farm loan programs” or "to provide farm credit to black farmers” would be an example of such coupling. ${ }^{15}$

\section{Mapping the Agenda of Civil Rights}

To facilitate analysis and the presentation of the findings, the following section of this chapter is structured according to the two following questions: "What receives attention?" and "Who has jurisdictional control?” The first question is intended to assess the level of activity and the issues that receive attention on the civil rights agenda, while the second question seeks to illustrate committee competition and policy monopoly. While the next chapter will further elucidate this activity, this chapter begins the exploration with the analysis of descriptive graphs and tables. Although more technical methods of analysis are available, descriptive graphs are effective because Baumgartner and Jones $(1993,269)$ state graphs “speak for themselves.”

\section{What Receives Attention?}

After employing the aforementioned search for civil rights there were a total of 1,650 introductions produced (Table 4.1). There were 1,321 in the House and 329 in the Senate. On the whole, civil rights received minimal attention in the immediate years following World War II. For the most part, most of the civil rights-related proposals centered primarily on employment issues. However this quickly changed, when attention to civil rights peaked in 1963-64 during the $88^{\text {th }}$ Congress. Particularly, the level of activity as measured by bill introductions has not been as striking since the height of the civil rights

\footnotetext{
${ }^{15}$ Majority of the titles were relatively distinct, making the coding of topics less ambiguous. However like most studies that involve content analysis, there were instances in which subjectivity was exercised.
} 
movement and the subsequent landmark Civil Rights Act of 1964. Table 4.1 and Figure 4.1 provide a broad picture of the integral level of attention toward civil rights. Aside from the dramatic increase and decrease in activity, what is also telling is the mix of issues on the agenda of the House and Senate, and how certain issues tend to receive more attention than others. As such, specific aspects of Figure 4.1 will be discussed in the subsequent sections to further clarify this observation. 
Table 4.1: Civil Rights Bill Introductions By Session

\begin{tabular}{|c|c|c|}
\hline Year & Session & I ntroductions \\
\hline 1939 & 76 & 0 \\
\hline 1941 & 77 & 1 \\
\hline 1943 & 78 & 8 \\
\hline 1945 & 79 & 21 \\
\hline 1947 & 80 & 17 \\
\hline 1949 & 81 & 22 \\
\hline 1951 & 82 & 18 \\
\hline 1953 & 83 & 21 \\
\hline 1955 & 84 & 65 \\
\hline 1957 & 85 & 98 \\
\hline 1959 & 86 & 122 \\
\hline 1961 & 87 & 182 \\
\hline 1963 & 88 & 279 \\
\hline 1965 & 89 & 257 \\
\hline 1967 & 90 & 33 \\
\hline 1969 & 91 & 48 \\
\hline 1971 & 92 & 24 \\
\hline 1973 & 93 & 19 \\
\hline 1975 & 94 & 44 \\
\hline 1977 & 95 & 42 \\
\hline 1979 & 96 & 25 \\
\hline 1981 & 97 & 34 \\
\hline 1983 & 98 & 31 \\
\hline 1985 & 99 & 26 \\
\hline 1987 & 100 & 14 \\
\hline 1989 & 101 & 27 \\
\hline 1991 & 102 & 50 \\
\hline 1993 & 103 & 54 \\
\hline 1995 & 104 & 46 \\
\hline \multirow[t]{2}{*}{1997} & 105 & 22 \\
\hline & Total & 1,650 \\
\hline
\end{tabular}


Figure 4.1: Civil Rights Bill Introductions 1940-1998

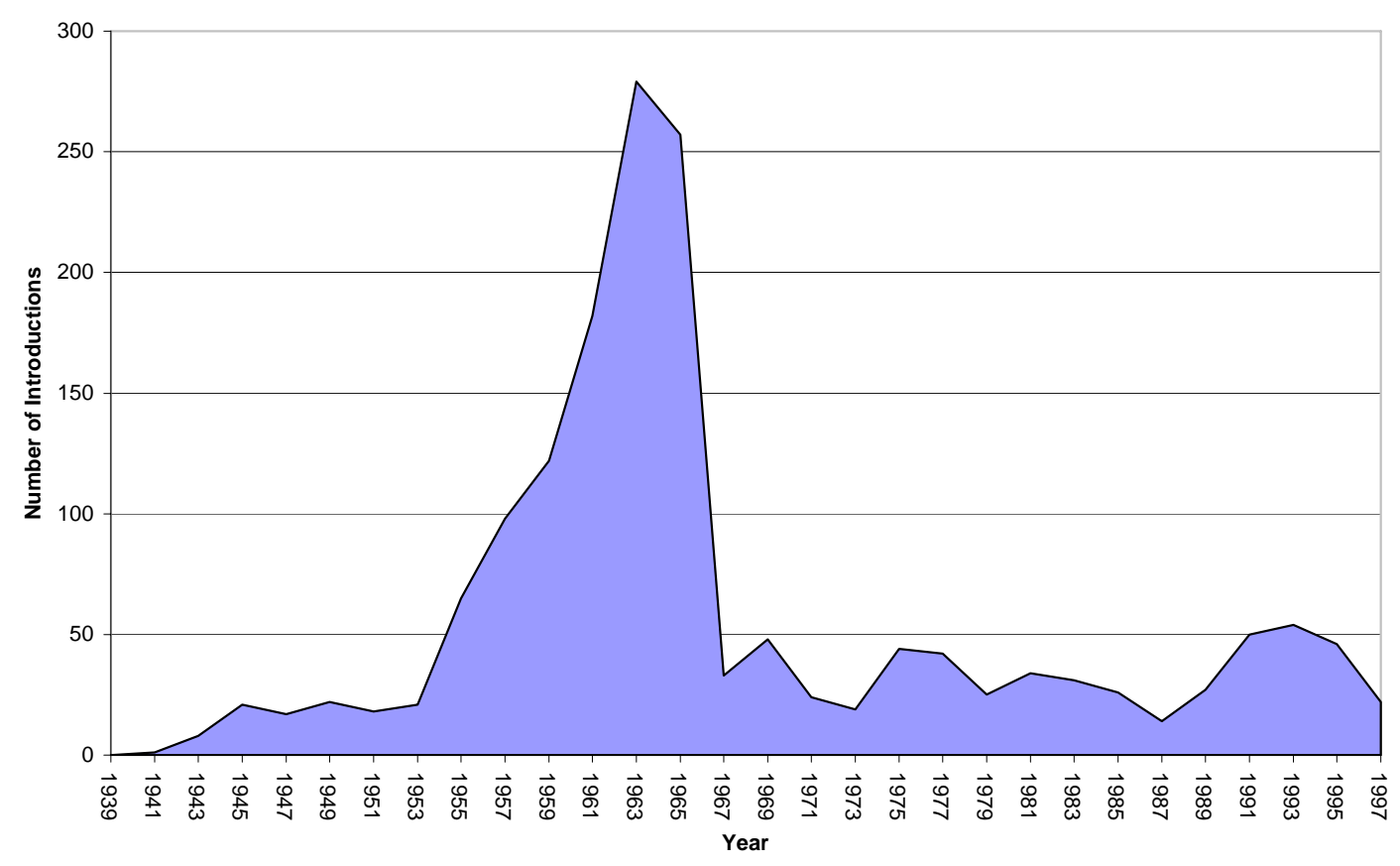

Succinctly, Figures 4.2 (House) and Figure 4.3 (Senate) explore the answer to the question “what receives attention”-in both chambers. From 1956-1963, advancing the cause of civil rights/civil rights amendments received the most attention in the House. Although not as acute, this issue is also on the Senate agenda along with other proposals that address violence, school desegregation, voting rights, and institutional housekeeping. Thus as illustrated in the figures, from 1957 through 1963, the House places more attention on one topic area, while the less active Senate introduces a mix of issues. Notably, in 1965 during the $89^{\text {th }}$ Congress, there is a dramatic shift in attention from civil rights amendments/constitutional rights to the topic of voting rights. Such an illustration is indicative of the passage of the Voting Rights Act of 1965. The emergence of voting rights is also realized in the Senate, but only with minimal attention. 
Figure 4.2: House Civil Rights Bill Introduction: Issue Composition

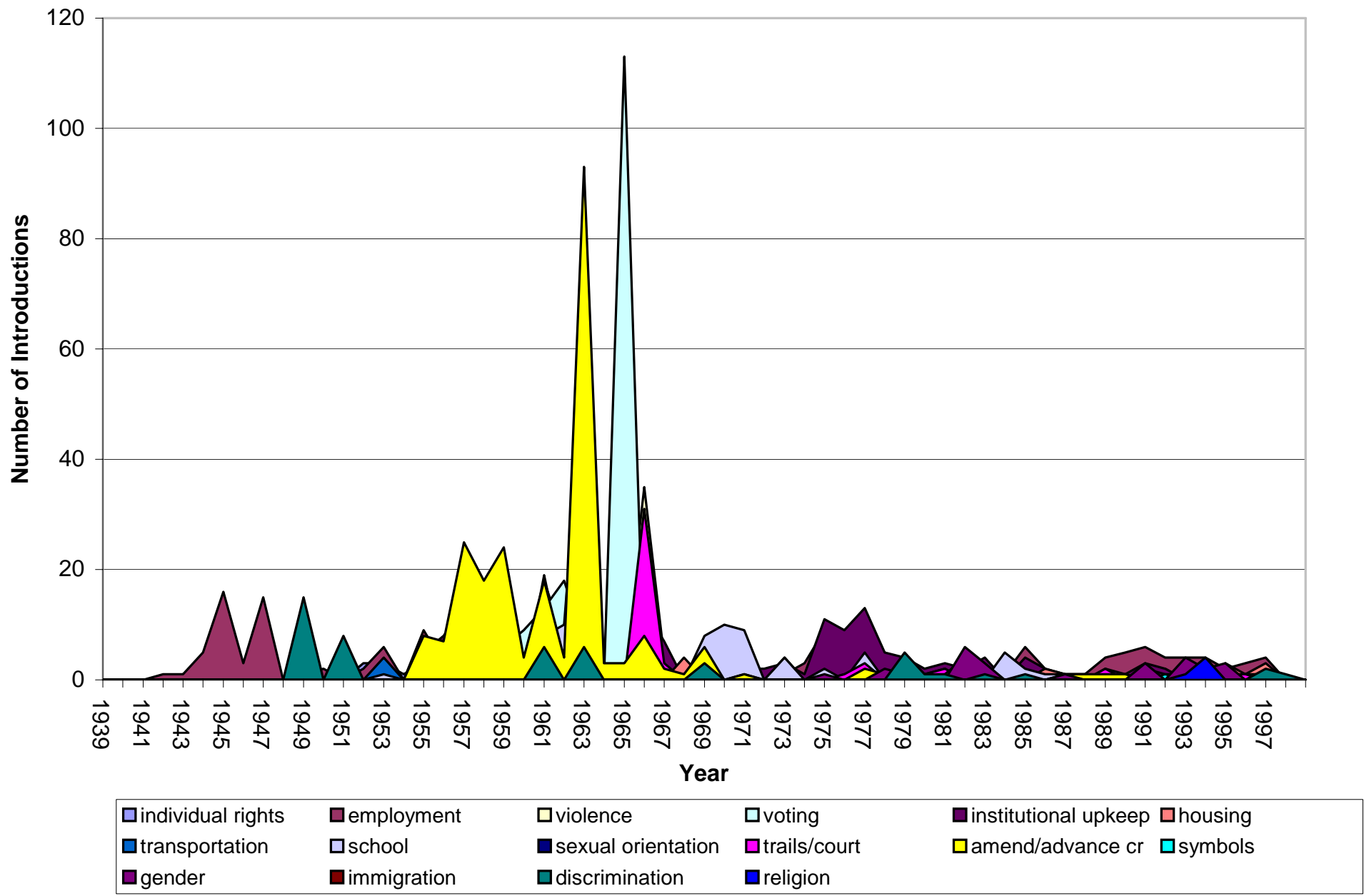


Figure 4.3 Senate Civil Rights Bill Introduction: Issue Composition

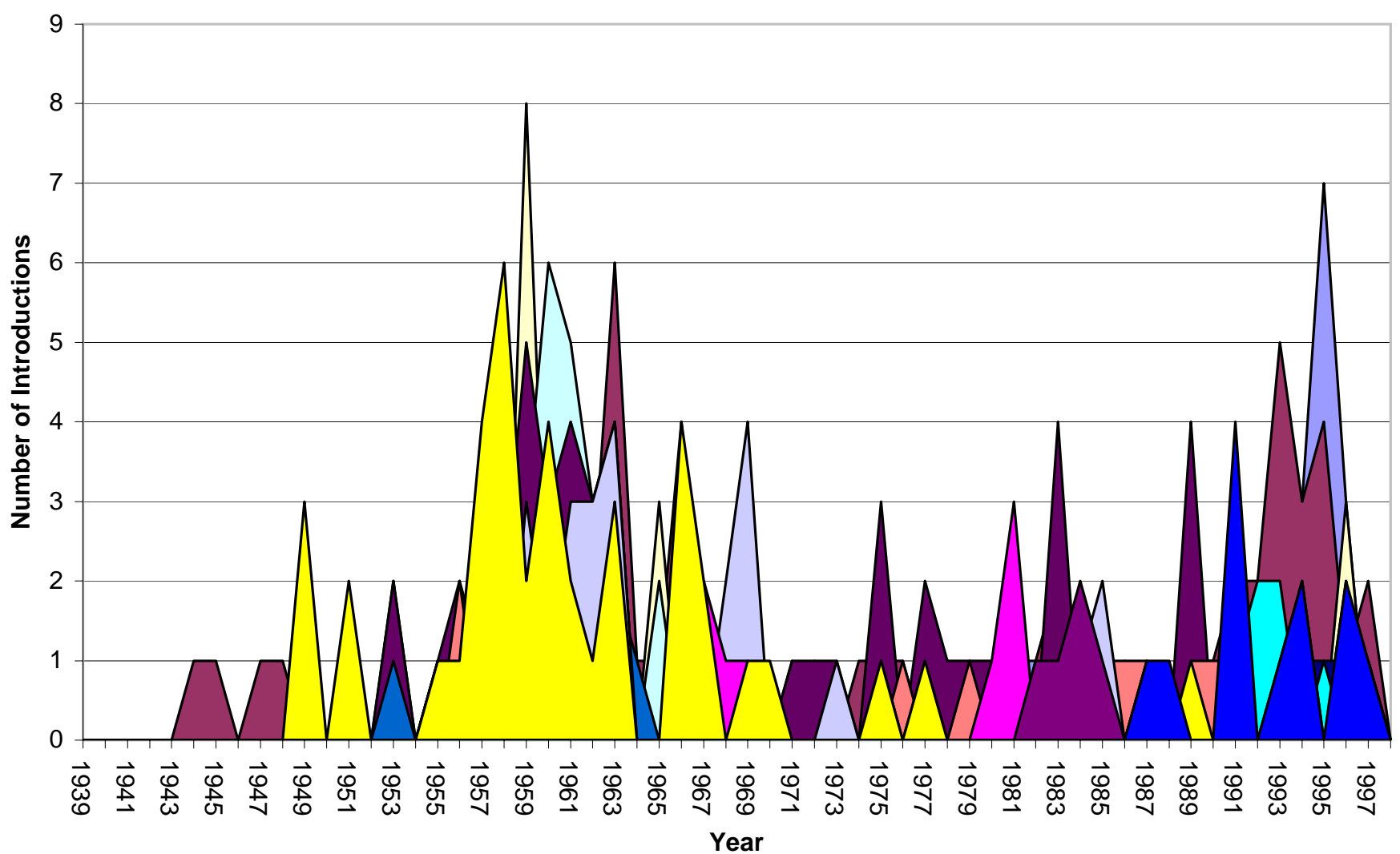

\begin{tabular}{|c|c|c|c|c|}
\hline $\begin{array}{l}\square \text { individual rights } \\
\square \text { transportion } \\
\square \text { gender }\end{array}$ & $\begin{array}{l}\square \text { employment } \\
\square \text { school } \\
\square \text { immigration }\end{array}$ & $\begin{array}{l}\square \text { violence } \\
\square \text { sexual orientation } \\
\square \text { discrimination }\end{array}$ & $\begin{array}{l}\square \text { voting } \\
\square \text { trails/court } \\
\square \text { religion }\end{array}$ & $\begin{array}{l}\square \text { institutional upkeep } \square \text { housing } \\
\square \text { amend/advance cr } \square \text { symbols }\end{array}$ \\
\hline
\end{tabular}

After 1967 the level of attention on civil rights wanes, but the agenda in both chambers becomes increasingly diverse and multi-issued. In particular, from the $90^{\text {th }}$ Congress to the end of the analysis period, civil rights policies proposed range from social and economic issues to overall individual and religious rights. This might be due to more specific entries in the Congressional Record, or it might accurately reflect the broader discussions of civil rights inspired by the Civil Rights Act of 1964. Klinkner and Smith (1999) provide some evidence for the latter, suggesting that the Act of 1964 served 
as a precursor to the variety of civil rights issues/reforms that emerged over the next three decades. An interesting aspect to this point is evident in the last eight years of the analysis. Particularly in the Senate from 1991 through 1998, issues concerning religious rights appear on the agenda. Aside from receiving only scant attention, what is most interesting is that such issues had not been explicitly introduced on the agenda prior to the watershed era of the $88^{\text {th }}$ Congress - thus confirming the previously stated observations of Klinkner and Smith (1999). Next, to further explore the civil rights agenda, the examination of bill referrals will be assessed to highlight possible occurrences of committee competition and policy monopoly.

\section{Who has Jurisdictional Control?}

Having mapped the issues on the agenda, the next question to examine is "who has jurisdictional control?” Bill referrals are beneficial in answering such a question because as King (1997) argues, referrals enable a committee to expand its jurisdictional prowess in the policy making process. Figures 4.4 and 4.5 illustrate this dynamic in both the House and the Senate. 
Figure 4.4: House Civil Rights Bill Referral: Com mittee Competition

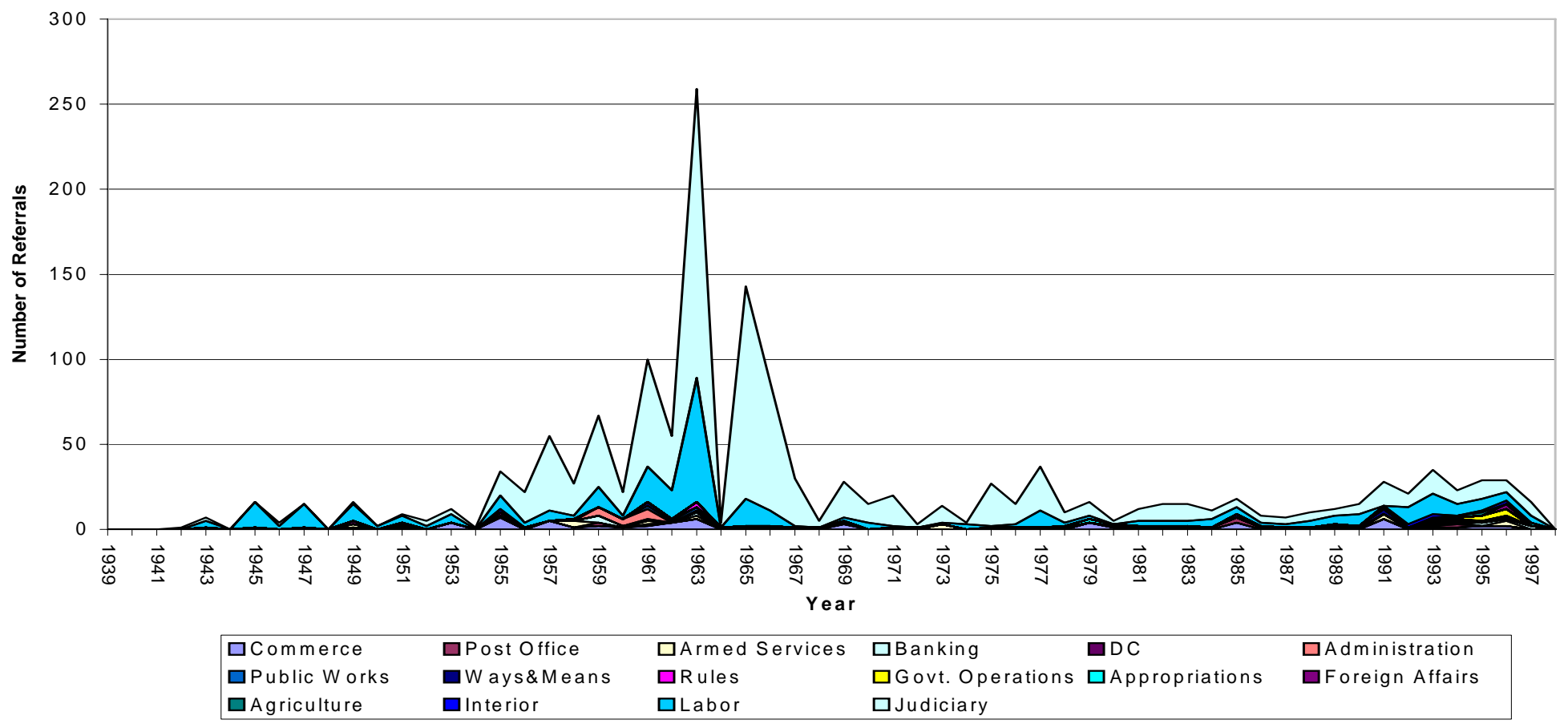


Figure 4.5: Senate Civil Rights Bill Referral: Committe Competition

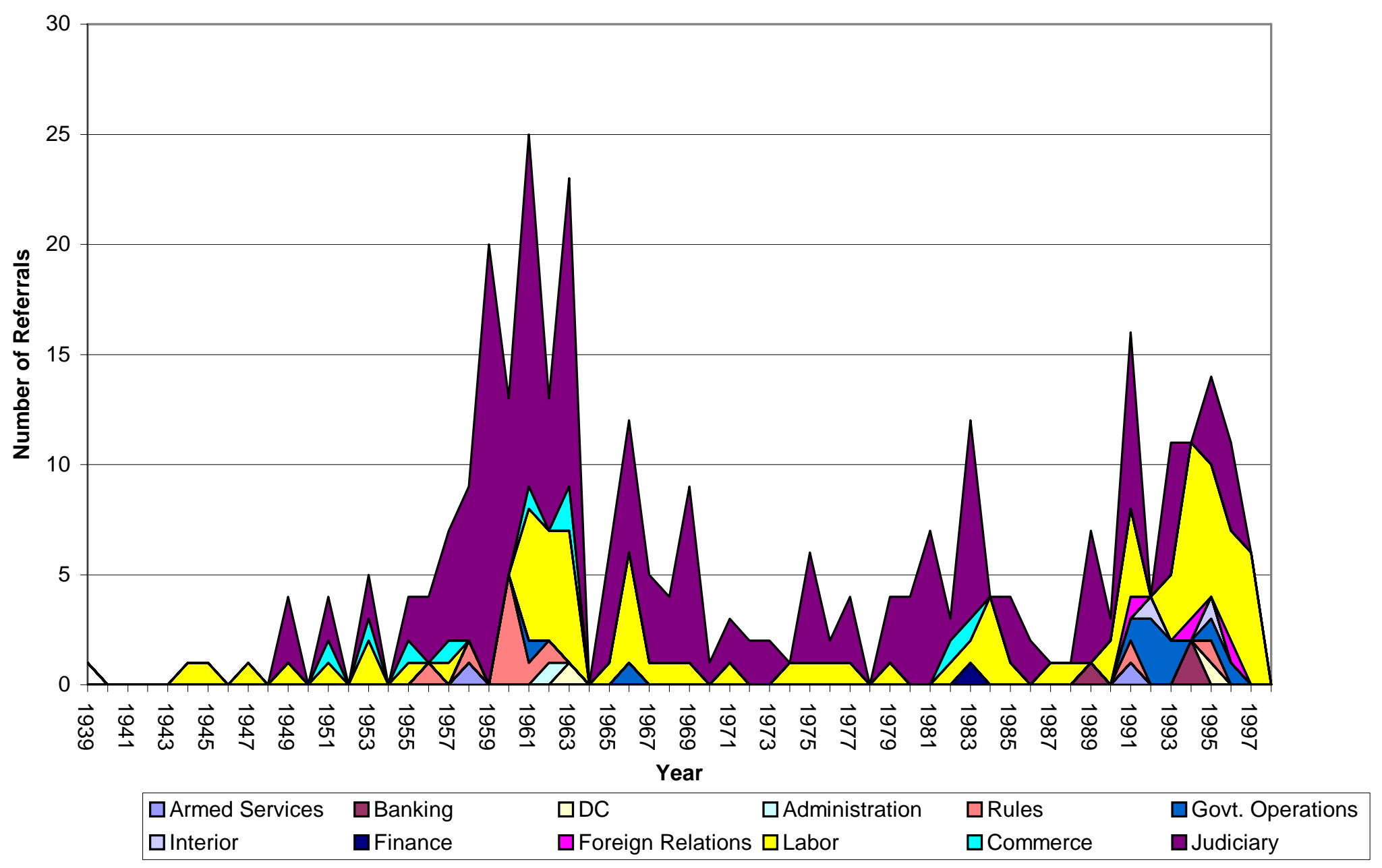

A few things are apparent from Figures 4.4 and 4.5 . First, over $65 \%$ of the issues present on the agenda in both chambers are referred to the Judiciary Committee. This is not surprising considering the common law jurisdiction the committee has in addressing issues of equality and rights. What is intriguing from these graphs is the early 1960s illustrate the existence of slight competition. In particular, during the era of the civil rights movement from 1959-1964, 25\% of the introductions are referred to the Labor 
Committee. In part, most of these proposals involve denying aid to educational institutions practicing discrimination. In addition, there is also a small bleep on the radar by the Administration Committee in the House and the Rules Committee in the Senate. The proposals that are referred to these committees involve voting rights issues—such as the elimination of the poll tax and the preservation of voting records. It is important to emphasize this juncture of small competition corresponds to the increase in attention to civil rights as noted in the previous section. As such, the apex in attention and the period of minor competition are both indicative of the civil rights movement and the Civil Rights Act of 1964.

By 1967 during the $90^{\text {th }}$ Congress, up until the early 1990s, committee competition diminishes along with the level of attention towards civil rights issues. Indeed, it appears the period of the civil rights movement and the subsequent Act of 1964 functions as a shock to the system. To some degree, we see that the disturbance is characteristic of negative feedback because the initial disturbance becomes smaller as it works its way through time (Baumgartner and Jones1993, 6). Not until 1991 are there evident observations of competition during the analysis period. As indicated by Figures 4.4 and 4.5, a marginal degree of competition is noticeable between 1991 and 1998. During this time span the bulk of civil rights proposals involved mainly economic and individual rights—issues, which were referred primarily to the Judiciary, Labor, and the Government Operations Committees. This minor vying between committees is reflective of the mix of topics that arise on the agenda in both chambers. Aside from marginal competition in the early 1960s and the minor degree of competition in the mid 1990s- 
particularly in the $104^{\text {th }}$ Congress, the Judiciary Committee is the most dominant venue for referrals through out the period under investigation.

To buttress the point of a policy monopoly being secured by the Judiciary Committees, Figures 4.6 and 4.7 present a Herfindahl index score for each chamber. A Herfindahl index score is calculated by squaring the proportion of committees holding referrals in the policy realm and then summing the squares of those proportions. The result is an index score that ranges from zero to one. A score close to zero indicates referrals are spread out among a large number of committees, while a score of one indicates that a single committee holds all the referrals (Worsham, 2004). As previously stated, and as indicated in the figures, the Judiciary Committee in both chambers dominated the referral of introductions, but again this control tends to vary during periods of competition—such as that of the early 1960s and the mid-1990s.

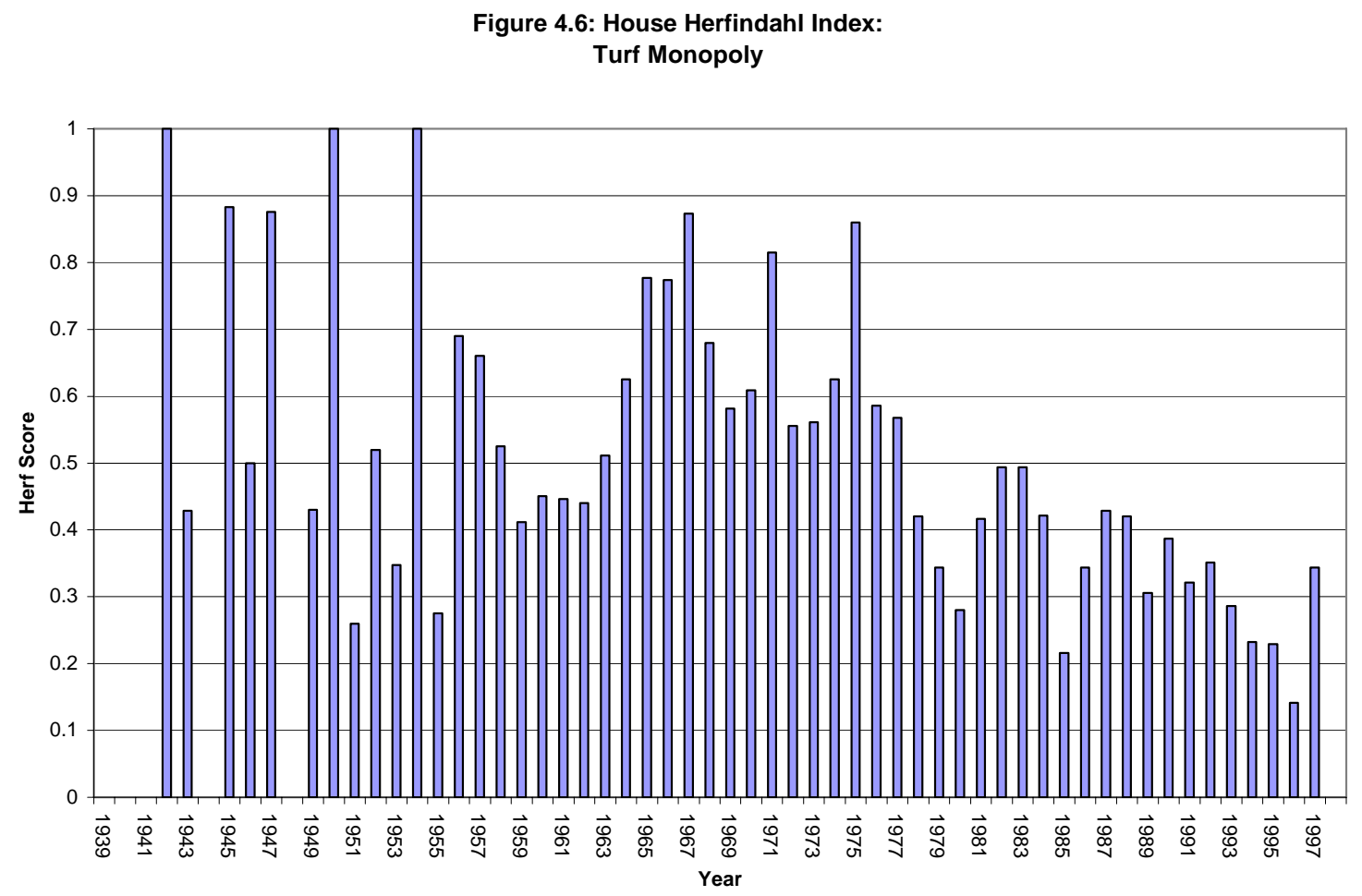


Figure 4.7: Senate Herfindahl Index:

Turf Monopoly

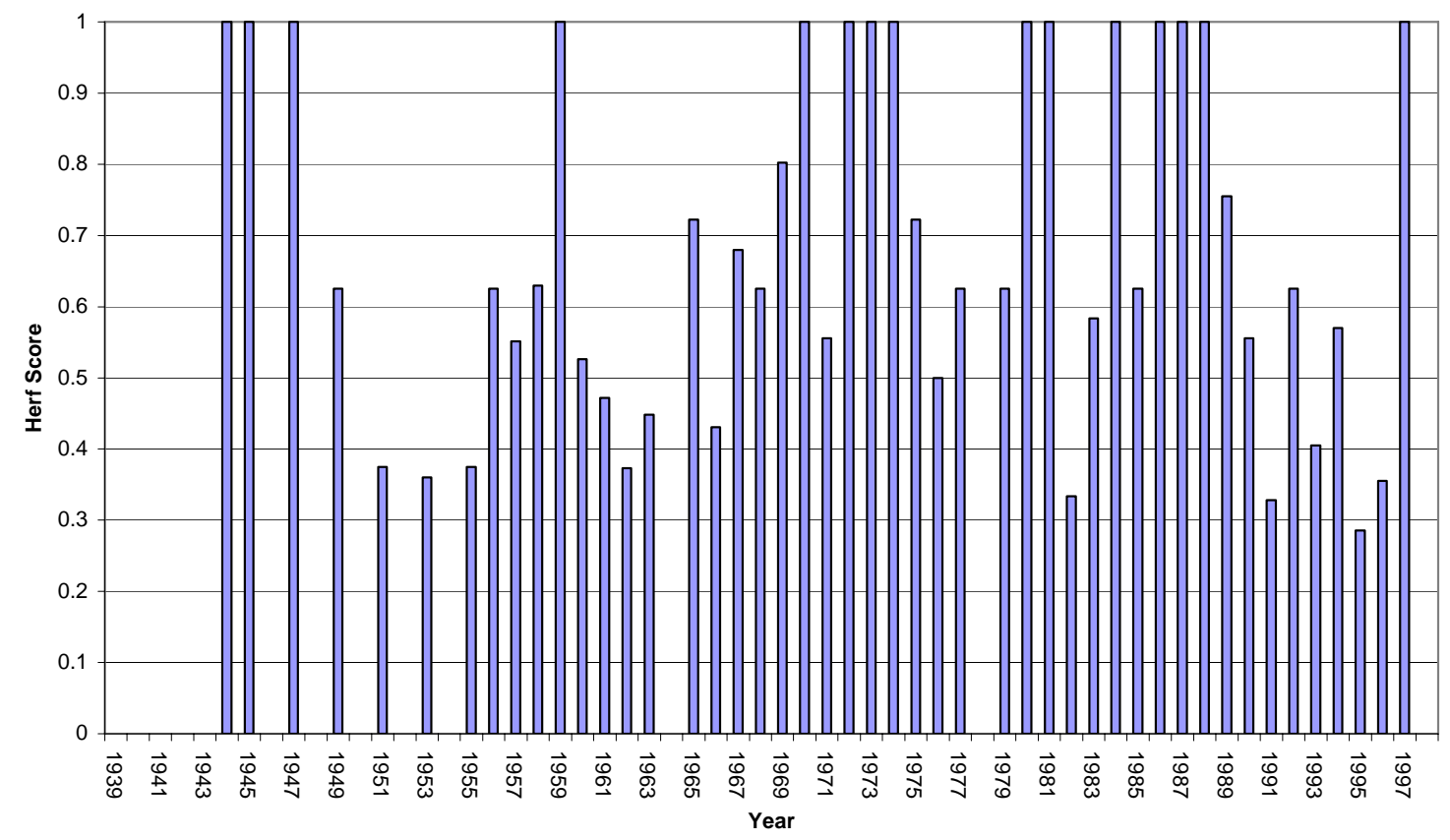

The preceding charts and observations provide a measure of the level of activity, what receives attention on the civil rights agenda and who maintains jurisdictional control over the referral of introductions. At the macro-level we can surmise that a relatively low number of issues comprise the early postwar civil rights agenda. Accordingly, these issues include prohibiting the practice of employment discrimination and the advancement of civil rights amendments. When the 1960s swept through—characterized by the Civil Rights Act of 1964 and the Voting Rights Act of 1965, the level of attention to civil rights and the degree of committee competition was at its apex. While the level of attention and competition soon relapsed, this particular juncture served as the foundation for the mix of issues that appeared on the agenda over the next three decades. 
That said, I will now turn my attention to the agricultural agenda and compare its patterns of activity to that of civil rights.

\section{Mapping the Agenda of Agriculture}

Following the same format used for examining civil rights, exploring the agricultural agenda adheres to the same line of questions: "What receives attention?" and "Who has jurisdictional control?” As was this case for civil rights, the first question examines the level of activity and what topics receive the most attention on the agenda, whereas the second question assesses committee competition and policy monopoly. To follow then, is a presentation of descriptive graphs and tables, which seek to clarify the two aforementioned questions. Similar to the previous section, presenting data graphically is effective because as the old saying goes "a picture tells a thousand words.”

\section{What Receives Attention?}

To begin, the agricultural agenda is much different in comparison to civil rights. All told, there were a total of 2,656 introductions (Table 4.2). There were 1,948 in the House and 708 in the Senate. Particularly, agriculture receives far more attention in the early 1940s than does civil rights. Much of this is due to the nexus between agriculture and the war, and Congress' interest in meeting military demands at home and abroad. However, as indicated by Figure 4.8, agriculture received scant attention during the immediate post war years. The level of attention and congressional intervention diminished during this period because the years following the war brought stability and a piece of prosperity to the farming community (Hurt, 1994). 
Table 4.2: Agriculture Bill Introductions By Session

\begin{tabular}{|c|c|r|}
\hline Year & Session & I ntroductions \\
\hline 1939 & 76 & 48 \\
\hline 1941 & 77 & 140 \\
\hline 1943 & 78 & 60 \\
\hline 1945 & 79 & 7 \\
\hline 1947 & 80 & 9 \\
\hline 1949 & 81 & 19 \\
\hline 1951 & 82 & 10 \\
\hline 1953 & 83 & 37 \\
\hline 1955 & 84 & 85 \\
\hline 1957 & 85 & 290 \\
\hline 1959 & 86 & 174 \\
\hline 1961 & 87 & 75 \\
\hline 1963 & 88 & 82 \\
\hline 1965 & 89 & 130 \\
\hline 1967 & 90 & 78 \\
\hline 1969 & 91 & 103 \\
\hline 1971 & 92 & 90 \\
\hline 1973 & 93 & 81 \\
\hline 1975 & 94 & 113 \\
\hline 1977 & 95 & 192 \\
\hline 1979 & 96 & 148 \\
\hline 1981 & 97 & 112 \\
\hline 1983 & 98 & 101 \\
\hline 1985 & 99 & 165 \\
\hline 1987 & 100 & 109 \\
\hline 1989 & 101 & 79 \\
\hline 1991 & 102 & 34 \\
\hline 1993 & 103 & 17 \\
\hline 1995 & 104 & $\mathbf{6 5 6}$ \\
\hline 1997 & 105 & \\
\hline & Total & \\
\hline
\end{tabular}


Figure 4.8: Agriculture Bill Introductions: 1940-1998

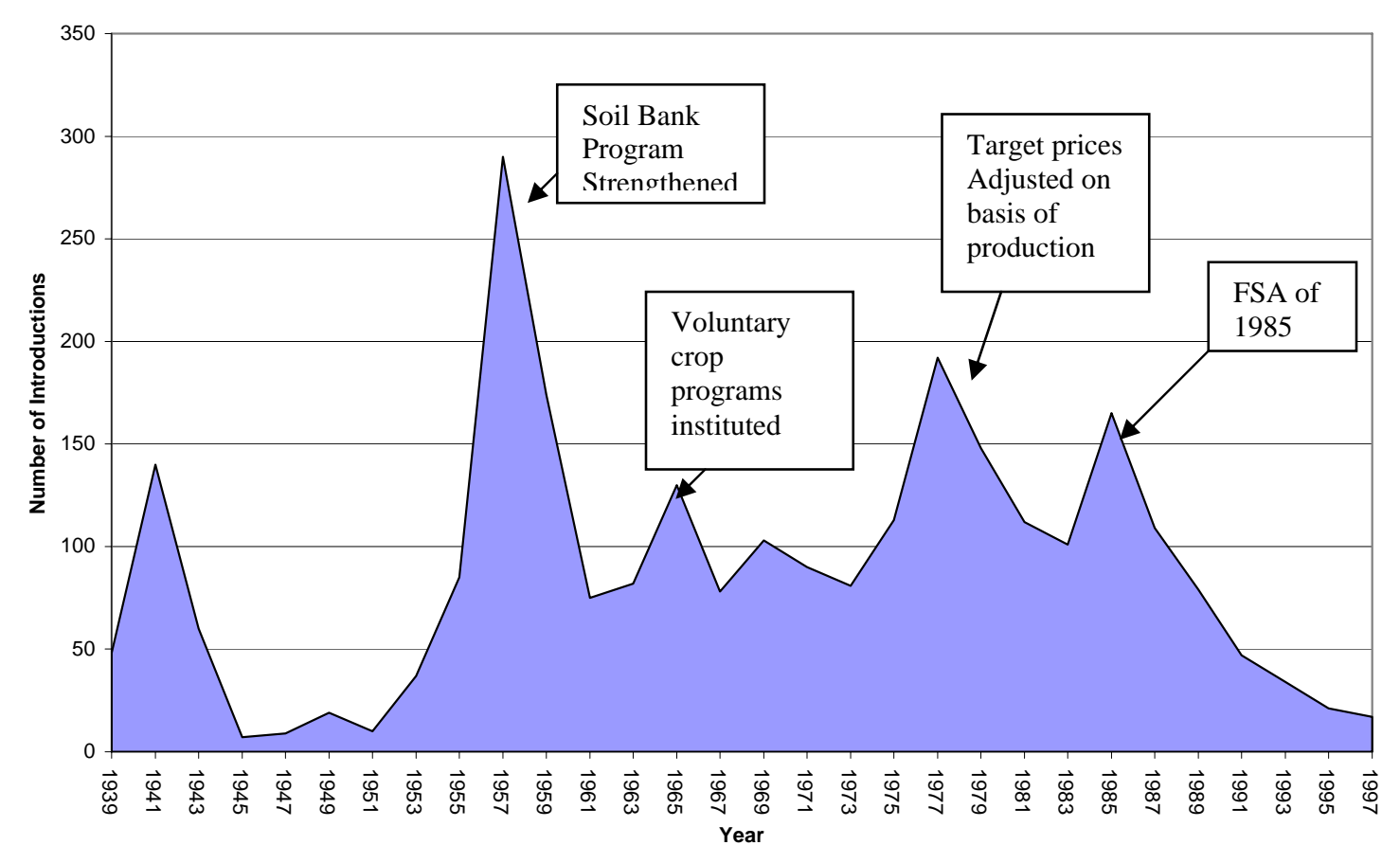

As illustrated in Figure 4.8, things soon changed when attention to agriculture peaked in 1957-58 during the $85^{\text {th }}$ Congress. As described in Chapter Two, this increase in attention is illustrative of Congress' interest in addressing the issue of surplus production. By 1961, the level of activity had tailed off and remained relatively steady for the next fifteen years. Not until 1977 during the $95^{\text {th }}$ Congress is there a noticeable change in activity. After the level of activity drops and rises over the next ten years, the end of 1987 marked the beginning of a steady decline in the attention to agriculture. In particular, by the end of the analysis period, agriculture received very little attention. The fluctuating level of activity and the issues that are shaping the agenda can be elucidated by turning to the question, "what receives attention?" 
Figures 4.9 (House) and 4.10 (Senate) illustrate the topics that receive attention on the agenda in both chambers. Evident in the House, price supports dominate the agricultural agenda during the early 1940s. Although proposals dealing with cotton and disaster assistance are present, price supports makeup 70\% of the topics on the agenda from 1940-1945. Comparably in the Senate, loans, price supports and cotton receive most of the attention—with loans and price supports comprising $67 \%$ of the topics on the agenda. Indicative of the dramatic shift in activity, the level of attention to price supports in 1957 during the $85^{\text {th }}$ Congress skyrockets in the House, and marginally increases in the Senate. This is realized because during this time Congress regarded price supports as the means to addressing the surplus production that was created during the war years. In addition to price supports, proposals centering on family farms and cotton related issues receive attention in the House as well. However unlike the House, the Senate also introduces loan proposals on the agenda. In essence, as Figures 4.9 and 4.10 indicate, the mid-1950s is characterized by an increase in issue topics, with price supports, cotton, and loan proposals receiving the majority of the attention.

What is interesting from Figure 4.10 (House) is that by 1969, at the start of the $91^{\text {st }}$ Congress, the topic of price supports falls from the agenda. This is primarily the result of the decrease in partisan politics over prices supports and agricultural policy as described by Hurt (1994). Over the next five years loan proposals comprise $73 \%$ of the topics on the agenda_-receiving most of the attention in the House. In comparison, the Senate introduces a mix of issues, but similar to the House, farm loans remain the dominant topic on the agenda. 
Figure 4.9: House Agriculture Bill Introduction: Issue Composition

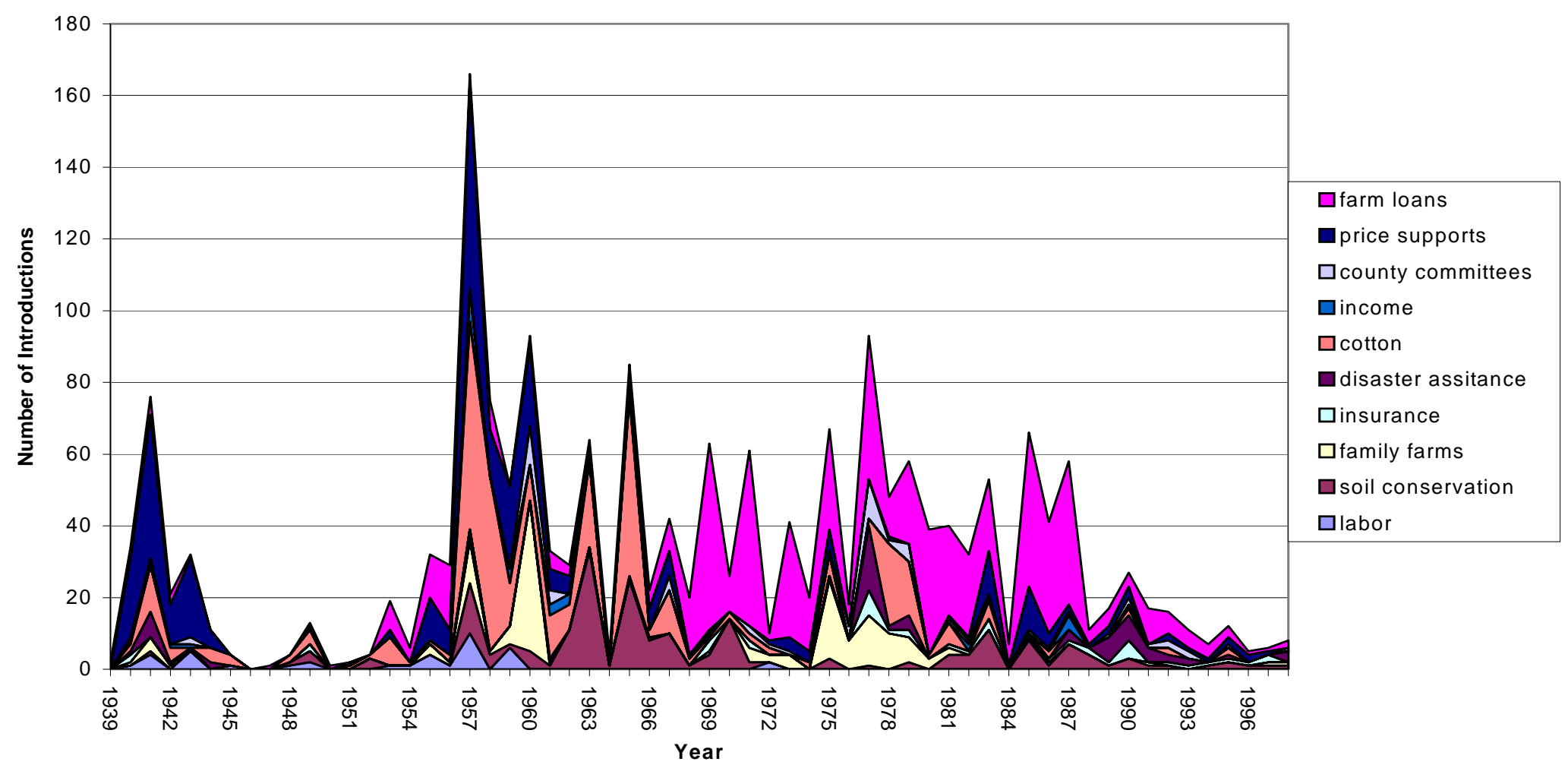


Figure 4:10: Senate Agriculture Bill Introduction:

Issue Composition

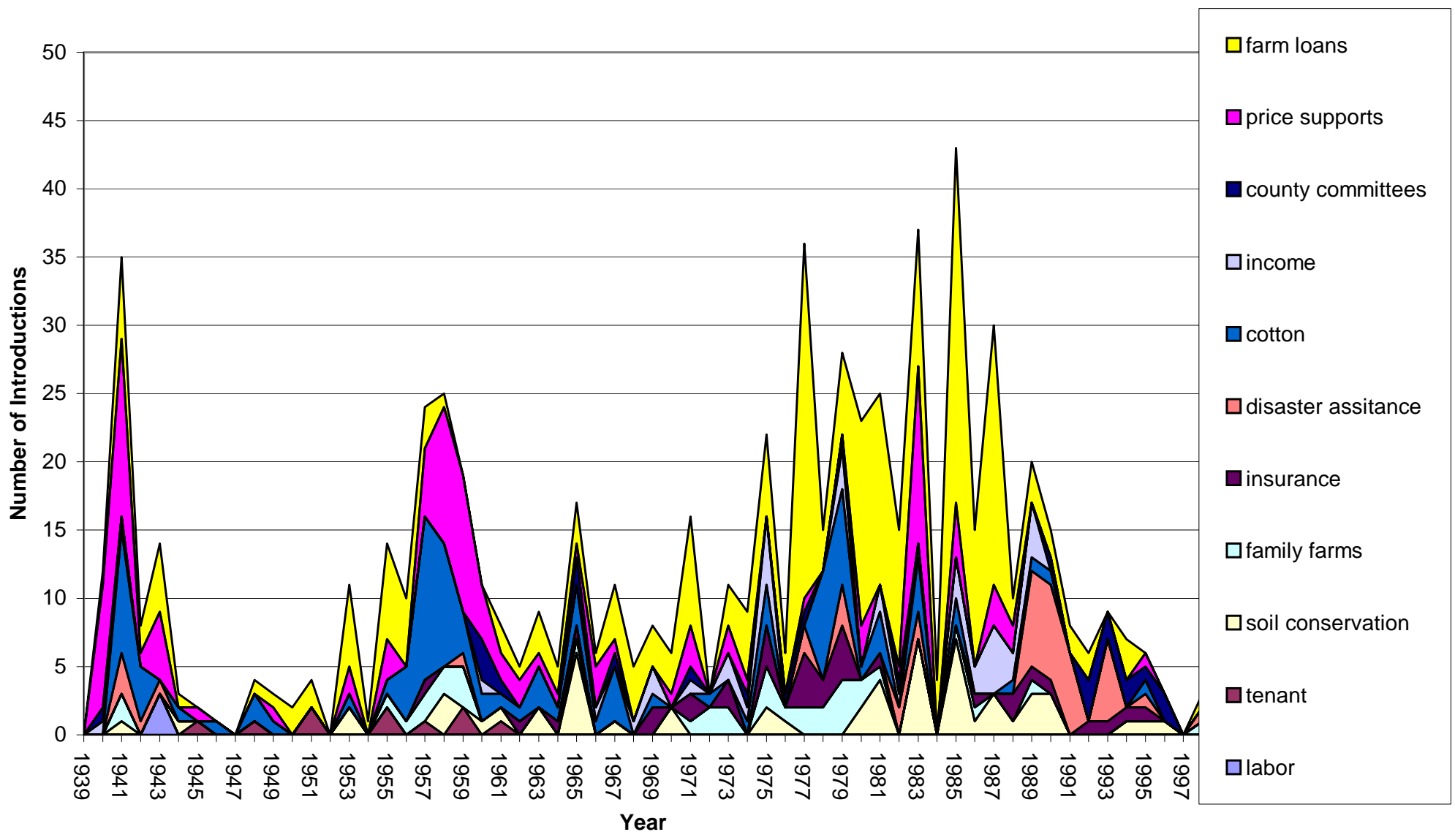

An interesting phenomenon illustrated in Figures 4.9 and 4.10 is the panoply of issues that emerge during 1975 through 1980. During this five year span the agricultural agenda in both chambers consists of an array of topics involving proposals dealing with disaster assistance, family farms, farm insurance, and cotton. In part, this increase in the number of topics can be attributed to the congressional reforms that took place between 1971 and 1977. Browne (1995) suggests that such reform decentralized committee power and as a result opened the door for the introduction of a mix of policy issues. 
Note that while the agenda in both chambers consist of a variety of topics, introductions pertaining to farm loans still comprise over $40 \%$ of the issues on the agenda. In sum, as the general level of activity declines throughout the 1990s, the mix of topics fades from the agenda. Now that I have assessed the composition of topics on the agenda, the next question involves jurisdictional control over legislative referrals.

\section{Who has Jurisdictional Control?}

Research suggests that legislative referrals are consequential to agenda setting because it illustrates the presence of committee competition and policy monopoly (King, 1997; Baumgartner and Jones, 1993). Thus, the occurrence of such competition can consequently disrupt subsystem arrangements and policy equlibria (Worsham 1997; Talbert, Jones and Baumgartner, 1995; Baumgartner and Jones, 1993) Therefore, the analysis of legislative referrals is important because it illustrates a committee's ability to control the agenda.

An interesting illustration in Figures 4.11 and 4.12 is the presence of mild competition between 1958 and 1989. In examining this trend, it is apparent that competition occurs in two separate time periods. The lesser of the two arises between 1958 and 1967. During this juncture $10 \%$ of the introductions are not referred to the Agriculture Committees. Notably, the Ways and Means and Post Office Committees are the primary venue, which receives these introductions. In particular, the introductions referred to the Ways and Means involve proposals related to farm income issues such as taxable income of farmers. Introductions referred to the Post Office Committee concern issues pertaining to county committees such as merit pay, and retirement insurance. 
Figure 4.11: House Agriculture Bill Referral:

Committee Competition

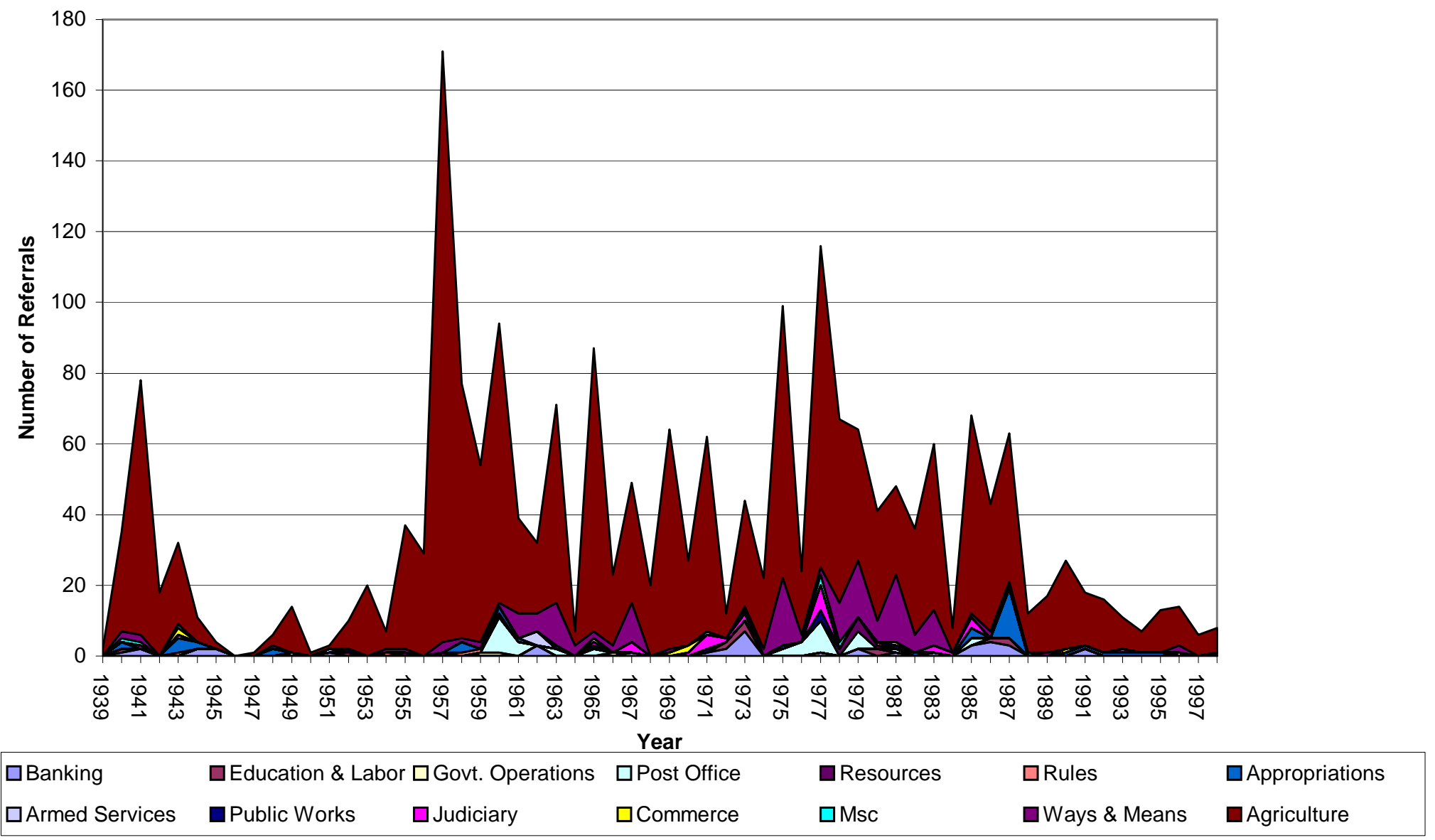


Figure 4:12: Senate Agriculture Bill Referral:

Committee Competition

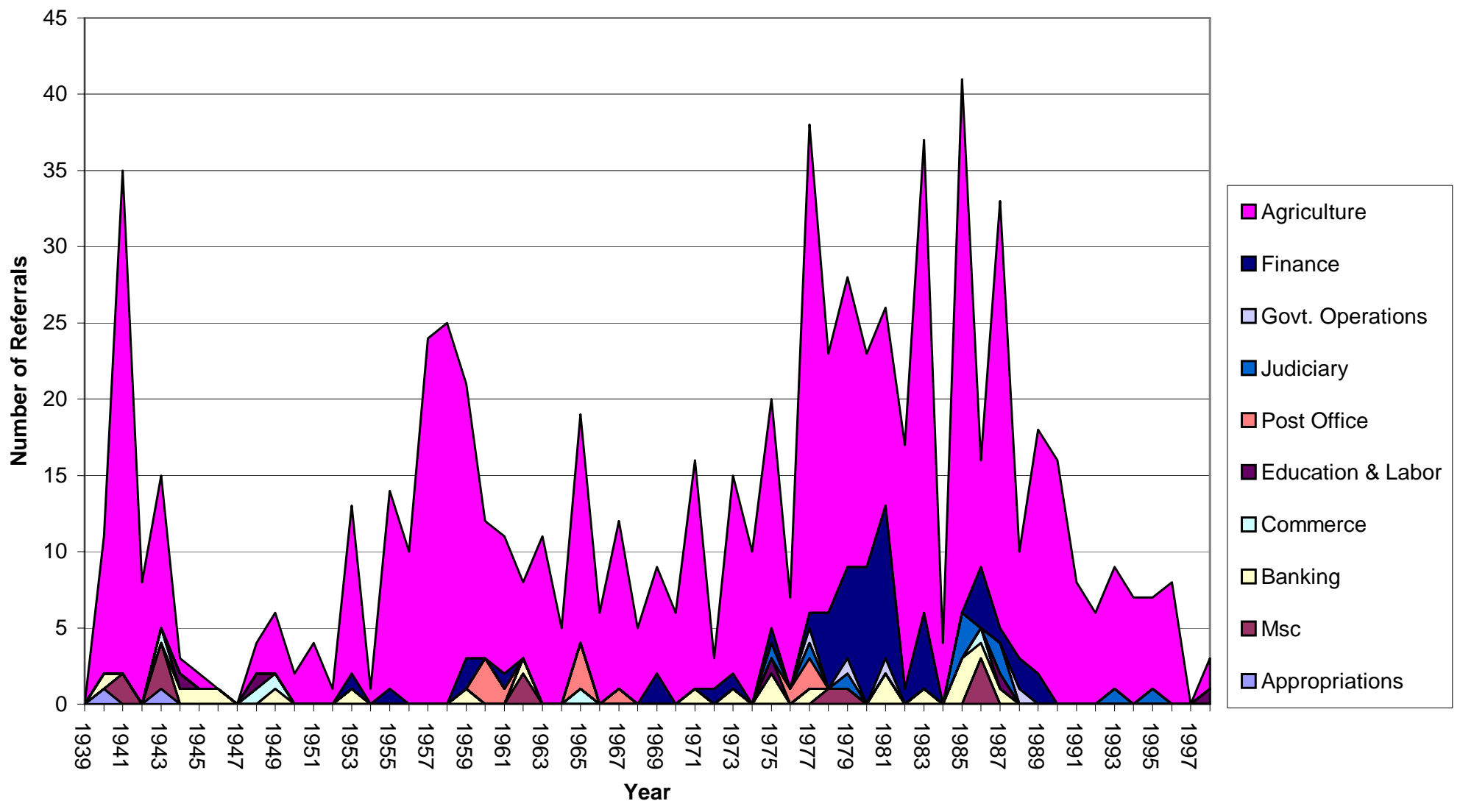

Perhaps the most telling trend in the graphs is the second period of competition, which exists from 1972 through 1988. As far as the research is concerned, this time span is particularly interesting due to the punctuating effects of the congressional reforms from 1971-1977, and the rise of the farm crisis from 1981-1986. During the reform era in the House (Figure 4.11) the Ways and Means, Post Office, and the Judiciary Committees combined receive a little more than $12 \%$ of the referrals during this juncture. 
The small number of introductions referred to the Judiciary and Ways and Means involve issues pertaining to family farmers, while referrals to the Post Office concern the pay of county committees. Aside from Agriculture, the two other committees that receive proposals include the Ways and Means and Appropriations. Introductions to the Ways and Means involve primarily the farm production of family farmers, while referrals to the Appropriations Committee focus on budget issues-pertaining particularly to the Farmers Home Administration and soil conservation. Notably, it is fair to postulate that the issue and referral of such introductions reflect the troubling times brought about by the farm crisis.

Turning to the Senate (Figure 4.12), the Finance, Post Office, and Judiciary Committees are involved in mild competition. For example, during the reform period the Finance, Post Office, and Judiciary Committees are referred a little more than $15 \%$ of the introductions. In particular, the Finance Committee receives most of these referralswhich center primarily on loan and price support issues. Similar to the House, the Post Office Committee in the Senate is also referred proposals concerning the pay of county committees. Also similar to the House, the Judiciary Committee receives bills pertaining to family farm aid. At the wake of the farm crisis, most of the introductions referred to the Finance Committee involve farm loan issues-partially related to recovery taxes. Other committees active during this mild period of competition include the Judiciary and Banking Committees. Once again, the introductions referred to Judiciary relate to family farm issues, whereas referrals to the Banking Committee involve issues of farm income such as credit and bankruptcy—concerns that are indicative of the crisis. 
Although there are periods of minimal policy competition, overall, the Agriculture Committee is the dominant institutional venue for the referral of agricultural introductions. To confirm the jurisdictional monopoly maintained by the Agriculture Committees and the presence of competition, Figures 4.13 (House) and 4.14 (Senate) contain Herfindahl index scores for each chamber. As demonstrated by the figures, referral of agricultural proposals resides primarily within the jurisdiction of the Agriculture Committees. However, during the reform and crisis period mild competition emerges, which in turn slightly disrupts the degree of dominance secured by the committees.

Figure 4.13: House Herfindahl Index: Turf Monopoly

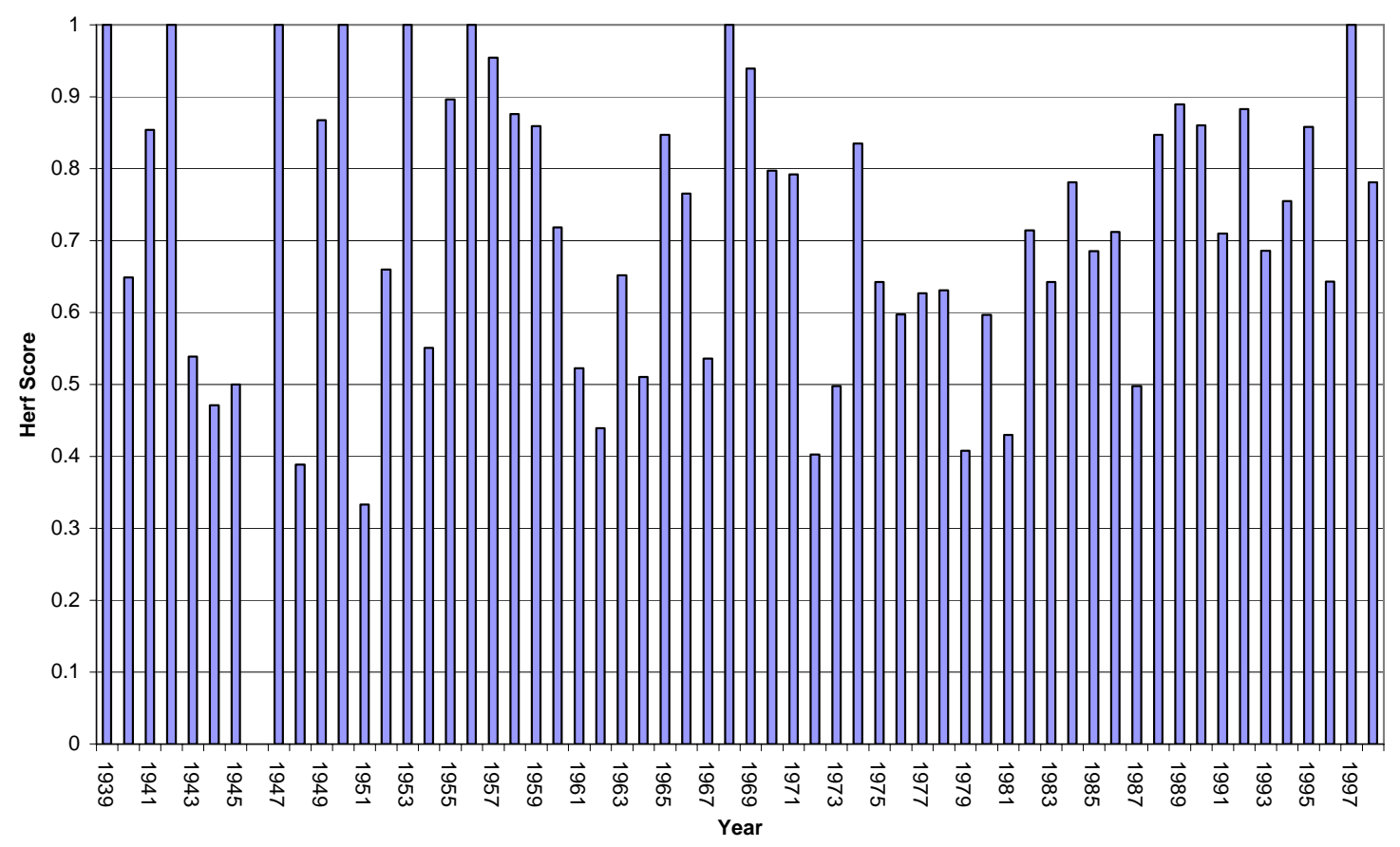


Figure 4:14: Senate Herfindahl Index: Turf Monopoly

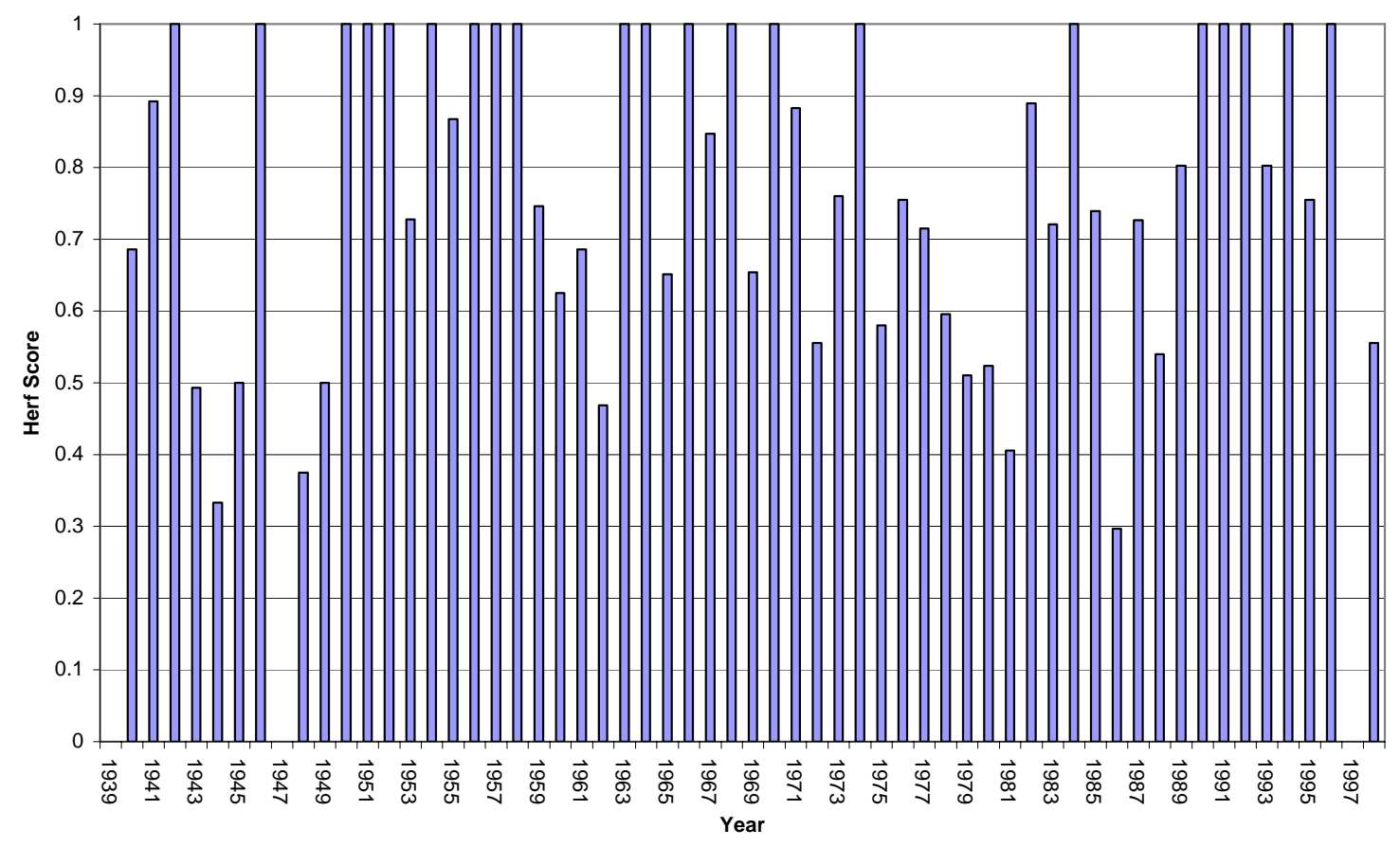

I have established that the Agriculture Committees maintain a policy monopoly over the referral of introductions throughout most of the analysis period. I have also discovered that during shocks to the system, mild committee competition arises. As such, I want to assess whether competition and the introductions that escape referral to the Agriculture Committee are sponsored by representatives outside the agricultural policy domain (i.e. the Agricultural Committee). The following section examines bill sponsorship in both chambers during the time period characteristic of mild referral competition (1972-1988). This particular time frame is examined because it exhibits the most competition throughout the analysis. Using the Congressional Directory I was able to determine whether the Chair of the Agriculture committee, the Ranking Minority member of the 
committee, a Republican in the committee, or a Democrat in the committee introduce proposals that escape referral to their committee. All nonmembers who introduce proposals are regarded as outsiders. The notion holds that insiders of the policy domain (i.e. Agricultural Committee) are less likely to sponsor a gamut of introductions that knowingly would be referred to another jurisdiction. As such, I concur with Rosenthal (1998, 131) who argues that a "bill will ordinarily be assigned to the committee on which the author serves or which he or she chairs.” That said, the preceding gives rise to the following hypotheses:

Hypothesis 1: Introductions that escape referral to the Agriculture Committee are less likely to be sponsored by representatives inside the policy domain.

Hypothesis 2: Representatives inside the policy domain are likely to sponsor more proposals assigned to the committee than they are to sponsor proposals that escape the committee.

Hypothesis 3: Policy-coupled introductions are more likely to be sponsored by Democrats than Republican representatives. ${ }^{16}$

These hypotheses are important to investigate because it helps highlight the origin and destination of legislative proposals that challenge policy jurisdiction and subsystem autonomy.

\section{Sponsorship and Committee Competition}

First, I will examine sponsorship in both chambers for all introductions that escape referral to the Agriculture Committee from 1972-1988. Afterwards, I will then assess all proposals that are assigned to the committee for the same time period. To begin, Tables 4.3 and 4.4 detail the percentage of bill introductions that are referred outside the

\footnotetext{
${ }^{16}$ As indicated previously in the chapter under the discussion of data collection, a policy-coupled introduction is one in which agriculture and civil rights is introduced jointly. For example, a bill title that states, "to prohibit discrimination in the delivery of farm loan programs" would be regarded as a policycoupled introduction.
} 
Agriculture Committee and those who sponsored the largest percentage of such introductions.

Table 4.3: House Introductions that escape referral to the Agriculture committee from 1972-1988

\begin{tabular}{|l|l|l|l|l|l|l|l|}
\hline & & & & SPONSORS & & & \\
\hline Year & $\begin{array}{l}\text { Total } \\
\text { number } \\
\text { of bill } \\
\text { referrals } \\
\text { that } \\
\text { escaped } \\
\text { committee }\end{array}$ & $\begin{array}{l}\text { Number } \\
\text { Minority }\end{array}$ & $\begin{array}{l}\text { Chair } \\
\text { Democrats }\end{array}$ & $\begin{array}{l}\text { Ranking } \\
\text { Republicans }\end{array}$ & Outsiders \\
\hline 1972 & 12 & 5 & & & 1 & & 4 \\
\hline 1973 & 44 & 14 & & & 1 & 3 & 10 \\
\hline 1974 & 22 & 2 & & & & & 2 \\
\hline 1975 & 99 & 22 & & & 14 & 1 & 7 \\
\hline 1976 & 24 & 6 & & & 1 & & 5 \\
\hline 1977 & 116 & 25 & & & 2 & 2 & 21 \\
\hline 1978 & 67 & 15 & & & 6 & 4 & 5 \\
\hline 1979 & 64 & 27 & & 2 & 6 & 5 & 14 \\
\hline 1980 & 41 & 10 & & & 4 & 1 & 5 \\
\hline 1981 & 48 & 23 & 1 & & 2 & 7 & 13 \\
\hline 1982 & 36 & 6 & & & 1 & 2 & 3 \\
\hline 1983 & 60 & 13 & & 1 & 1 & 1 & 10 \\
\hline 1984 & 8 & 1 & & & & 1 & 1 \\
\hline 1985 & 68 & 12 & & & 1 & 1 & 10 \\
\hline 1986 & 43 & 7 & & & 2 & 1 & 4 \\
\hline 1987 & 63 & 21 & & & 1 & 2 & 18 \\
\hline 1988 & 12 & 1 & & & 1 & & $\mathbf{1 3 2}$ \\
\hline Total & $\mathbf{8 2 7}$ & $\mathbf{2 1 0}$ & $\mathbf{1}$ & $\mathbf{3}$ & $\mathbf{4 4}$ & $\mathbf{3 0}$ \\
\hline Percentage & & $\mathbf{2 5 \%}$ & $\mathbf{1 \%}$ & $\mathbf{1 \%}$ & $\mathbf{2 1 \%}$ & $\mathbf{1 4 \%}$ & $\mathbf{6 3 \%}$ \\
\hline & & & & & & \\
\hline
\end{tabular}


Table 4.4: Senate Introductions that escape referral to the Agriculture committee from 1972-1988

\begin{tabular}{|c|c|c|c|c|c|c|c|}
\hline & & & & SPONSORS & & & \\
\hline Year & $\begin{array}{l}\text { Total } \\
\text { number } \\
\text { of bill } \\
\text { referrals }\end{array}$ & $\begin{array}{l}\text { Number } \\
\text { that } \\
\text { escaped } \\
\text { the } \\
\text { committee }\end{array}$ & Chair & $\begin{array}{l}\text { Ranking } \\
\text { Minority }\end{array}$ & $\begin{array}{l}\text { Committee } \\
\text { Democrats }\end{array}$ & $\begin{array}{l}\text { Committee } \\
\text { Republicans }\end{array}$ & Outsiders \\
\hline 1972 & 3 & 1 & & & & & 1 \\
\hline 1973 & 15 & 2 & & 1 & & 1 & 1 \\
\hline 1974 & 10 & & & & & & \\
\hline 1975 & 20 & 5 & & & 1 & & 4 \\
\hline 1976 & 7 & 1 & & & 1 & & \\
\hline 1977 & 38 & 6 & & & 2 & & 4 \\
\hline 1978 & 23 & 6 & & & 1 & & 5 \\
\hline 1979 & 28 & 9 & & & & & 9 \\
\hline 1980 & 23 & 9 & & & & & 8 \\
\hline 1981 & 26 & 13 & 1 & & 2 & & 7 \\
\hline 1982 & 17 & 1 & & & & & \\
\hline 1983 & 37 & 6 & & & & & 6 \\
\hline 1984 & 4 & & & & & & \\
\hline 1985 & 41 & 6 & & & 5 & & 1 \\
\hline 1986 & 16 & 9 & & & 3 & & 6 \\
\hline 1987 & 33 & 5 & & & 1 & & 4 \\
\hline 1988 & 10 & 3 & & & 1 & & 1 \\
\hline Total & 351 & 82 & 1 & 1 & 17 & 1 & 57 \\
\hline Percentage & & $23 \%$ & $1 \%$ & $1 \%$ & $21 \%$ & $1 \%$ & $70 \%$ \\
\hline
\end{tabular}

As indicated in Tables 4.3 (House) and 4.4 (Senate), there were a total of 1,178 introductions from 1972-1988. There were 827 in the House and 351 in the Senate. Of the 827 in the House, 25\% escaped referral to the Agriculture Committee, while $23 \%$ of the 351 escaped the Agriculture Committee in the Senate. As far as policy entrepreneurs are concerned, the committee chair and ranking minority member sponsor $1 \%$ of all proposals that escape referral to the committees. In particular, Democrats in the House sponsor $21 \%$ of the introductions that escape referral and $21 \%$ in the Senate, whereas Republicans sponsor $14 \%$ in the House and $7 \%$ in the Senate. The majority of introductions that escape the Agriculture Committees are sponsored by outsiders at 63\% in the House and $70 \%$ in the Senate. 
On a general level, there are issues topics which both parties tend to sponsor, at least based on the introductions. In the House, both Democrats and Republicans sitting on the Agriculture Committee sponsor more loan-based proposals—-the majority of which are referred to the Ways and Means Committee. Probably the most interesting aspect regarding the two parties is the fact that during the mid-1970s Democrats sponsored over 95\% of all proposals dealing with family farm issues - the majority of which were referred to the Ways and Means Committee. This difference is likely the result of liberal, democratic congressmen that were ushered in by the reforms that was described by Zelizer (2004) and Sheingate (2001). In the Senate the difference is less dramatic. For instance, both parties sponsor loan proposals, however, Democrats tend to sponsor more county committee issues, while Republicans introduce more price support proposals.

Next, Tables 4.5 (House) and 4.6 (Senate) illustrate the sponsorship of introductions assigned to the Agriculture Committee from 1972-1988. As illustrated, members within the agricultural domain sponsor more introductions assigned to the committee than they do those from outside. For example, the committee chair in the House sponsors 3\% of the introductions referred to the committee, whereas the ranking minority member sponsors $4 \%$. In comparison, the committee chair in the Senate sponsors $13 \%$ of the introductions referred to the committee, while the ranking minority member sponsors $8 \%$. Notably, the committee chair and the ranking minority member in both chambers tend to sponsor cotton, price support and loan related proposals. In addition, in both the House and Senate, Democrats are more active—sponsoring 33\% and $25 \%$ of introductions assigned to the committee. Conversely, Republicans sponsor $17 \%$ in the House and $18 \%$ in the Senate. There is more parity between the two parties in the 
fact that both Democrats and Republicans sponsor more loan proposals than any other topic. Likewise in the Senate, both parties comparably sponsor more loan and price support proposals. However, Republicans tend to be slightly more active than Democrats in sponsoring cotton related proposals.

Table 4.5: House Introductions assigned to the Agriculture committee from 1972-1988

\begin{tabular}{|c|c|c|c|c|c|c|c|}
\hline & & & & SPONSORS & & & \\
\hline Year & $\begin{array}{l}\text { Total } \\
\text { number } \\
\text { of bill } \\
\text { referrals }\end{array}$ & $\begin{array}{l}\text { Number } \\
\text { assigned to } \\
\text { the } \\
\text { committee }\end{array}$ & Chair & $\begin{array}{l}\text { Ranking } \\
\text { Minority }\end{array}$ & $\begin{array}{l}\text { Committee } \\
\text { Democrat }\end{array}$ & $\begin{array}{l}\text { Committee } \\
\text { Republican }\end{array}$ & Outsider \\
\hline 1972 & 12 & 7 & 1 & & 1 & 1 & 4 \\
\hline 1973 & 44 & 30 & & & 10 & 3 & 17 \\
\hline 1974 & 22 & 20 & & & 4 & 8 & 8 \\
\hline 1975 & 99 & 77 & & 8 & 20 & 7 & 42 \\
\hline 1976 & 24 & 18 & & & 5 & 3 & 10 \\
\hline 1977 & 116 & 91 & & & 23 & 14 & 54 \\
\hline 1978 & 67 & 52 & 2 & & 26 & 6 & 18 \\
\hline 1979 & 64 & 37 & & 2 & 17 & 5 & 13 \\
\hline 1980 & 41 & 31 & 1 & & 17 & 6 & 8 \\
\hline 1981 & 48 & 25 & 2 & 5 & 8 & 2 & 8 \\
\hline 1982 & 36 & 30 & 1 & 4 & 12 & 6 & 7 \\
\hline 1983 & 60 & 47 & 1 & 2 & 15 & 12 & 17 \\
\hline 1984 & 8 & 7 & & & 4 & 1 & 2 \\
\hline 1985 & 68 & 56 & 4 & 1 & 13 & 18 & 20 \\
\hline 1986 & 43 & 36 & 2 & & 12 & 8 & 14 \\
\hline 1987 & 63 & 42 & 3 & 1 & 16 & 4 & 18 \\
\hline 1988 & 12 & 11 & & & 2 & 1 & 8 \\
\hline Total & 827 & 617 & 17 & 23 & 205 & 105 & 268 \\
\hline Percentage & & $75 \%$ & $3 \%$ & $4 \%$ & $33 \%$ & $17 \%$ & $43 \%$ \\
\hline
\end{tabular}


Table 4.6: Senate Introductions assigned to the Agriculture committee from 1972-1988

\begin{tabular}{|l|l|l|l|l|l|l|l|}
\hline & & & & SPONSORS & & \\
\hline Year & $\begin{array}{l}\text { Total } \\
\text { number } \\
\text { of bill } \\
\text { referrals }\end{array}$ & $\begin{array}{l}\text { Number } \\
\text { assigned to } \\
\text { the } \\
\text { committee }\end{array}$ & Chair & $\begin{array}{l}\text { Ranking } \\
\text { Minority }\end{array}$ & $\begin{array}{l}\text { Committee } \\
\text { Democrat }\end{array}$ & $\begin{array}{l}\text { Committee } \\
\text { Republican }\end{array}$ & Outsider \\
\hline 1972 & 3 & 2 & 1 & & & & 1 \\
\hline 1973 & 15 & 13 & 3 & 2 & & 2 & 6 \\
\hline 1974 & 10 & 10 & 1 & 1 & 1 & 5 & 2 \\
\hline 1975 & 20 & 15 & 1 & 2 & 4 & 3 & 5 \\
\hline 1976 & 7 & 6 & & 1 & 1 & 1 & 3 \\
\hline 1977 & 38 & 32 & 4 & 3 & 11 & 3 & 11 \\
\hline 1978 & 23 & 17 & 4 & 3 & 4 & 1 & 5 \\
\hline 1979 & 28 & 19 & 4 & & 8 & 4 & 3 \\
\hline 1980 & 23 & 14 & 3 & 1 & 4 & 2 & 4 \\
\hline 1981 & 26 & 13 & 5 & 2 & 2 & 1 & 3 \\
\hline 1982 & 17 & 16 & 1 & 1 & 5 & 3 & 6 \\
\hline 1983 & 37 & 31 & 4 & 1 & 7 & 8 & 11 \\
\hline 1984 & 4 & 4 & & & 1 & 2 & 1 \\
\hline 1985 & 41 & 35 & 1 & 3 & 7 & 6 & 18 \\
\hline 1986 & 16 & 7 & & & 1 & 7 & 6 \\
\hline 1987 & 33 & 28 & 2 & 1 & 8 & 7 & 10 \\
\hline 1988 & 10 & 7 & & & 3 & 1 & $\mathbf{9 8}$ \\
\hline Total & $\mathbf{3 5 1}$ & $\mathbf{2 6 9}$ & $\mathbf{3 4}$ & $\mathbf{2 1}$ & $\mathbf{6 7}$ & $\mathbf{4 9}$ & $\mathbf{3 6 \%}$ \\
\hline Percentage & & $\mathbf{7 7 \%}$ & $\mathbf{1 3 \%}$ & $\mathbf{8 \%}$ & $\mathbf{2 5 \%}$ & $\mathbf{1 8 \%}$ & \\
\hline
\end{tabular}

Throughout this analysis I have implicitly made reference to the policy coupling of civil rights with agriculture issues and have yet to render any information to illustrate such an occurrence. Therefore, before concluding this chapter, the following section will address this issue by examining the proposals that exhibit coupling. Evidence of this amalgam is probably best seen through a discussion detailing the sponsorship, content, and fate of the legislation joining together civil rights and agriculture. To simplify the discussion I will first briefly present the proposals that never move past committee referral. Thereafter, I will examine the proposal that resulted in legislation benefiting African American farmers. In part, the following discussion works to form the basis for a portion of the analysis in the next two chapters. 


\section{Policy-coupling and Legislative Entrepreneurs}

All told, there were a total of seven proposals that exhibited policy coupling. In 1969, Congressmen John Hagan (D-GA), Marvin Esch (R-MI), and Leonard Blanton (D-TN), who were all outsiders of the policy domain, each sponsored a proposal dealing with the issue of prohibiting discrimination in administering crop insurance. After each proposal was referred to the Agriculture Committee, no further action was granted to the proposals. I contend coupling was not successful during this period due in large part to the existence of dominant subsystem politics. It was not until the early 1970s with the congressional reforms when this form of politics was diluted. But, it is worth noting that each of these proposals surfaced after 1964—again confirming the observations of Klinkner and Smith (1999) who suggests the Civil Rights Act of 1964 was the foundation for forthcoming civil rights issues and reforms.

In 1997 Congresswoman Cynthia McKinney (D-GA) also an outsider of the policy domain, sponsored a proposal in the House that sought to provide a mechanism for addressing certain complaints of discrimination arising out of the administration of programs of the USDA. After being referred both to the Judiciary and Agriculture Committee, her proposal received no further attention from either committee. In addition, in 1997 during the $105^{\text {th }}$ Congress, Congresswoman Eva Clayton (D-NC) a member of the Agriculture Committee sponsored a proposal that sought to restructure the Farm Service Agency (FSA) county committees to ensure minority representation, and to ensure minority farmers could obtain credit and other assistance to maintain their farms. During the same year chairman of the Agriculture Committee, Robert Smith (R-OR) 
introduced a proposal that also sought to reorganize the USDA by combining the FSA and the Natural Resources Conservation Service (NRCS) into a single agency within the USDA. Not only did Smith’s proposal seek to restructure the agency, but it also included provisions to ensure the equitable treatment of socially disadvantaged farmers and ranchers. After both proposals were referred to the Agriculture Committee, a hearing was granted to discuss the details of both proposals. After the lengthy hearing was concluded, no further attention was given to the proposals sponsored by Clayton and Smith. Details about the hearing and the witnesses that testified will be discussed in the next chapter.

The punctuating event of the class action lawsuit that surfaced the previous year along with the numerous "listening sessions" on discrimination held by the USDA around country throughout 1995-1997, were in part the impetus for the proposals that emerged in 1997 protecting minority farmers. ${ }^{17}$ Interestingly enough, each of the aforementioned proposals introduced during the $105^{\text {th }}$ Congress that aimed at assisting/protecting black farmers was contingent upon reorganizing the USDA. Browne $(1995,151)$ argues many members of Congress view the USDA as integral to national agricultural policymaking. Thus, anything that may jeopardize the agency’s ability to remain resourceful and influential would seem to be difficult to garner support for, not to mention the resistance that would be staged by USDA officials. And if reorganizing the USDA was not going to occur, then equality for black farmers would be compromised as well. Moreover, the proposals by Clayton and McKinney also had to travel the waters of a Republican majority in both the House and Senate Agriculture Committee-which also proved contentious.

\footnotetext{
${ }^{17}$ Insight about the numerous "listening sessions” held by the USDA will be revisited in Chapter Six.
} 


\section{Success in 1990: Policy Entrepreneurship and the Minority Farmers Rights Act}

Browne $(2003,143)$ states, "by 1990 complaints from black farmers to their own local members of Congress had reached, in one member's words, “epidemic levels.” Thus, if civil rights were going to be successfully attached to agricultural policy, and result in legislation, then it appears as though it was going to be formulated and solidified by the resilient and collaborative efforts of organized interests and policy entrepreneurs. If Browne's assertion of "epidemic levels" is correct, then it would be rational for some member or members of Congress to address or at least attempt to better the circumstances of their constituency. King (1997) contends that policy entrepreneurs are not motivated solely by elections, but also by instituting good public policy. Kingdon $(1995,123)$ argues that many policy entrepreneurs advocate certain proposals because they want to affect the shape of public policy according to the values and or interests they hold. Thus, being able to bring forth policy change is an important incentive for many legislative entrepreneurs to act.

Perhaps the most pertinent proposals to this analysis occurred in 1990 during the $101^{\text {st }}$ Congress. Congressman Mike Espy (D-MS) and Senator Wyche Fowler (D-GA) both insiders in the agricultural policy domain, sponsored the House and Senate version of Minority Farmers Rights Act, which added an amendment (section 2501) to the Food, Agriculture, Conservation, and Trade Act (FACT) of 1990. Congressman Espy gathered opinions and information about what the bill should look like during his meeting with The Federation of Southern Cooperatives/Land Assistance Fund (FSC/LAF) (Sherrod, 2004). Provisions included funding for outreach and education; targeting of Farmers Home Administration Ownership and Operating Loans; inclusion of more people of color 
on USDA staff and committees; a registry of minority farmers; and a report on civil rights performance and enforcement in all USDA program (Sherrod, 2004). After first being introduced by Espy on June 28, 1990, the bill was referred to the House Agriculture Committee, which was agreed to by voice vote and was subsequently introduced by Senator Fowler on July 19, 1990. After being read twice and assigned to the Agriculture, Nutrition, and Forestry Committee, the amendment passed in the Senate by a voice vote on July 26, 1990 and took effect on October 1, 1990 (Thomas.loc.gov). As described in Chapter 2, this was the first direct response from Congress that authorized money for outreach and technical assistance for low-income farmers and ranchers of color. Successfully introducing the Minority Farmers Rights Act was a clear illustration of the dynamic and comprehensive structure of the 1990 farm bill described by Browne (1995, 43).

Failed attempts to successfully join civil rights and agriculture are an illustration of what Herbert Simon $(1983,84)$ describes as a "conflict of multiple values.” Simon argues that political institutions have a difficult time simultaneously dealing with numerous policy issues because the goals underlying these issues are frequently represented by conflicting values. This is particularly true when such values center on redistributive policymaking as described by Lowi (1969). In addition, each failed attempt of policy coupling lends support to the observations of Baumgartner and Jones $(1993,29)$ that no single entrepreneur can unequivocally guarantee that their proposal to address a particular problem will be adopted due to the various conflicting interests involved in policymaking. Second, the various failed attempts highlight the point made by Browne $(1995,58)$ that the origin of issue initiatives within agricultural policy is biased toward 
the protection and maintenance of existing programs. Wildavsky (1997) suggests that changes to public policy usually occur incrementally, and Browne $(1995,57)$ asserts this is typically the case for agriculture policy. With this in mind, a policy or program aimed at assisting black farmers was less likely to occur as a sweeping reform—particularly if doing so meant dismantling an existing agricultural program. Thus, any changes that occurred would need to be storied with a larger farm bill—as was the case with the Minority Farmers Rights amendment of the 1990 FACT Act

Notably, successful policy coupling that occurred in 1990 during the $101^{\text {st }}$ Congress was the ability of policy insiders Mike Espy and Wyche Fowler to operate in "parallel" with one another. This form of processing was initiated at the "micro level" because it was first their individual actions that sought to wed civil rights and agriculture, not the president, and at the time not the courts. ${ }^{18}$ As such, I am not looking to confirm the existence of a civil rights subsystem as I have for agriculture, but what I argue is that the aforementioned instances of policy coupling-particularly successful coupling is an indication of what Worsham (1998) suggests as competitive subsystem politics. This is illustrated in the fact that civil rights advocates and interests sought to alter the decisionmaking venue of agricultural policy by replacing distributive policy with more radically redistributive policy (see Worsham 1998, 489). In addition, the ability of Espy and Fowler to deal with the controversial issue of amalgamating civil rights and agriculture was accommodated by the fact that Democrats were the majority in both the House and Senate Agriculture Committees. Moreover, agricultural policymaking during the early

\footnotetext{
${ }^{18}$ The following chapter will detail how activity by black farming interest groups was also instrumental in initiating the change carried out by Espy and Fowler.
} 
1990s was also characteristic of bipartisan cooperation, thus opposition by conservative Republicans sitting on the Agriculture Committees was less acute.

\section{Conclusion}

This chapter illustrated which issues on the civil rights and agricultural agenda receive attention, and where jurisdictional control and committee competition reside. The analysis of introductions sponsored by members of the Agriculture Committee from that sponsored by nonmembers helped illustrate policy disequilibria. In addition, by examining the sponsorship of policy coupled proposals one gets a feel for issue salience in the chamber as a whole, and the legislative entrepreneurs responsible for the framing of such proposals.

In the early years prohibiting employment discrimination was the main issue on the civil rights agenda. After the wake of the Civil Rights Act of 1964 the soil became fertile for new issues. In the late-1950s throughout the early 1960s attention to civil rights peaked, and while the level of activity tailed off in the late 1960s, the agenda became more comprehensive for the next three decades. The resulting diversity of issues on the agenda—social, economic, and individual rights—provided the Judiciary Committee the opportunity to guide the civil rights agenda for some time.

Similar to civil rights, agriculture in the late 1950s illustrated an overall increase in activity. Notably, as the congressional reforms took place from 1971-77, the agenda came to mean more things to more people and, once the farm crisis emerged in 1981, a larger mix of issues comprised the agenda-not to mention the presence of committee competition. While the majority of the bill introductions that escape referral to the Agriculture Committee were sponsored by members outside the policy domain, 
representatives of the Agriculture Committees sponsored the bulk of proposals assigned to the committee. Suggesting the period of mild referral competition was in part the effect of issue framing by policy entrepreneurs outside the agriculture policy domain. Notably, Democrats were more assertive in their entrepreneurial efforts to fuse civil rights and agriculture for the betterment of African American farmers.

It is important to note that even though policy coupling was not always successful, it does illustrate the partisan differences that are inherent in agenda setting. This confirms the observations by Baumgartner and Jones (1993, 22) who assert, Democrats generally stand in favor of the less-favored classes, while Republicans tend to support the more affluent. This demarcation of party lines is plausible because scholars contend party affiliation matters in the agenda setting of public policy (BoxSteffensmeier, Arnold, Zorn, 1997; Schiller, 1995; Sinclair, 1989). The next chapter will further explore the participants of agenda setting by taking a closer look at congressional hearings and the witnesses that tend to dominate the debate. 


\section{Analyzing Agricultural Agenda Setting And Efforts of Issue Redefinition}

"Any committee may hold hearings on any topic it pleases, even
those clearly within the jurisdiction of another committee."

- Baumgartner and Jones (1993, 200)

The previous chapter suggested that noticeable changes in the agricultural agenda as measured by bill introductions, occur as a result of punctuating events. In some instances policy coupling raises questions as to whether general legislative interest and activity is exhibited by Congress as a whole, or primarily by legislative entrepreneurs. Thus, this chapter is the second step in exploring and assessing the agenda of agricultural support policy through the examination of legislative hearings.

Wilkerson, Feeley, Schiereck, and Sue (1999) found that increases in bill introductions lead to increases in hearings. With this in mind, this chapter explores whether periods of change in the agricultural agenda as measured by bill introduction activity, equate to a similar change in hearing activity. This analysis includes both legislative and nonlegislative hearings. As important as legislative hearings are to agenda setting, nonlegislative hearings are also consequential to the process because they provide legislative entrepreneurs an inside route to initiate issue-redefinition by encroaching on the established jurisdiction of a particular committee (Talbert, Jones, and Baumgartner 1995, 383). There are four particular elements I will explore in this chapter concerning the agricultural agenda.

First, I want to assess the overall level of hearing activity in both chambers. Similar to bill introductions, this provides a general understanding of the level of 
attention Congress gives to agricultural policy of special concern to African American farmers. This longitudinal approach is beneficial because it highlights whether a change in activity corresponds to a particular “punctuating event.” Kingdon (1984) contends that such focusing events are important because they have the potential to influence the national agenda.

Second, I will explore the dynamics of policy jurisdiction and policy monopoly. By examining which committee or committees hold hearings, and whether hearing activity varies according to shocks to the system, I am able to determine whether a change in activity is in part conditioned by periods of punctuation, and thus resulting in the institutionalization of particular interests in the policy process. Third, I want to explore which witnesses participate in hearings - paying close attention to the hearings in which civil rights advocates are present. I track witnesses so as to assess the interests who tend to dominate the discussion. In part, this discussion serves to highlight the various policy-coupled hearings (legislative and nonlegislative) and the legislative entrepreneurs that partake in the hearing.

Finally, I explore whether policy disequilibria caused by punctuating events corresponds to a change in legislative outputs. A basic theme of this study is how the problems faced by black farmers were exacerbated by the passive and at times antagonistic actions of Congress. Ideas about this congressional activity are notable in the evolution of agricultural policy and confirmed by mapping the agenda as presented in Chapter Four. This chapter is the second step in understanding the dynamic agenda of agricultural support policy through legislative hearings and witness participation. 


\section{Data Collection}

I focus on congressional hearings in this chapter because as prior research suggests, hearings can include efforts of issue redefinition as well as attempts to maintain the status quo (Hunt, 2002; Tzoumia, 2001; Baumgartner and Jones, 1993). Sabatier and Jenkins Smith (1993) suggest that examining hearings in aggregate form over time is useful in identifying pertinent differences in the set of interests active on a particular issue. Likewise, Hardin (2002) illustrates hearings are a key method by which Congress gathers policy information, and the witnesses who testify exhibit the policy interests that Congress is willing to consider. Furthermore, Valerie Hunt $(2002,79)$ states that in many instances congressional entrepreneurs and political actors within a policy subsystem utilize hearings as a way to buttress their existence and dominance in particular policy jurisdiction, as well as stake claim to new issues. The fact that congressional hearings may serve as fact-finding exercises, an assessment of entrepreneurial activity, or a barometer of efforts of issue definition, makes the interests who testify at these hearings all the more relevant. Therefore, examining hearings over time and across the spectrum of congressional committees provides a plausible representation of the interests that members of Congress are willing to hear from, and the potential influence they may have on the agricultural agenda.

Utilizing the Congressional Information Index to Committee Hearings and Abstracts to Committee Hearings, I was able to track all hearings dealing with the following search topics: agricultural credit, agricultural insurance/disaster assistance, and 
farm income. ${ }^{19}$ The search focused primarily on these items not only because it provided a more refined sense of the agriculture issues of immediate concern to African American farmers, but an extensive amount of time and additional resources would have been needed to code a more exhaustive list of items. ${ }^{20}$ To identify a hearing where civil rights and agriculture intersect, I employed the same approach performed for bill introductions. For example, whenever any of the hearings produced from the aforementioned agricultural search topics made reference to the following topics: civil rights, African Americans, black Americans, colored people, negro/negroes, race relations, racial discrimination, racial segregation, equality along with any related "see also" term, it was dully noted as a policy-coupled hearing. This was performed in order to track all hearings where agriculture and civil rights explicitly intersect.

As is the case for most forms of content analysis, there are some gray areas involved in the coding process. I tried to follow the "mostly" rule of thumb as discussed by Babbie (1998, 314)—meaning what is the content of the material mostly about. For example, an abstract about acreage limitation provisions would seem to be mostly about farm income, while a hearing about providing assistance for soybean crop losses due to natural disasters appears to be mostly about agricultural insurance/disaster relief. As previously stated this involves some gray areas, thus rendering the results imperfect.

\footnotetext{
19 These search items were selected according to the study conducted by the US Commission on Civil Rights detailing the plight of African American farmers. The U.S. Commission on Civil Rights. (1982). The Decline of Black Farming in America: A Report of the United States Commission on Civil Rights. Washington, D.C.: GPO.

${ }^{20}$ Future research will look to explicitly include extension services, cotton production and livestock production.
} 


\section{Deciphering Agricultural Hearing Activity}

Figure 5.1 indicates the level of activity in both the House and Senate is comparably the same. The primary difference between the two chambers is the House conducts more hearings by a margin of almost 50\%. Up until the mid 1970s the level of activity is somewhat sporadic in both chambers, but essentially inconsequential in terms of considerable change. However, in 1956 and 1961 there is a marginal increase in the House, but not nearly as momentous as the change that occurs during the 1970s and 1980s in both chambers. Specifically, the House went from holding one hearing in 1972 to a total of 17 in 1976, while the Senate went from holding no hearings in 1972 to a total of 17 in 1976 . Notably during this period of increase, $80 \%$ of the hearings focused on agricultural credit and farm income-particularly on agricultural credit. This variation occurs and coincides with the numerous institutional changes associated with the “punctuating” congressional reform era from 1971-1977. As research suggests such reform decentralized committee power (Davidson and Oleszek, 2004; Ernstes, Outlaw, and Knutson, 1997; Browne, 1995) thus allowing for an increase in hearing activity as well as jurisdictional struggle (Baumgartner and Jones, 1993).

Likewise, the early 1980s indicated a rise in activity, particularly in 1983. This level of activity corresponds with the emergence of the "farm crisis" that rocked the farming community from 1981-1986. The high times that many farmers experienced during the 1970s came crashing down during the early 1980s. As a result, scholars suggest (Alston, Rucker and Weidenmier, 2000; Cochrane and Runge, 1992) the wake of the crisis evoked congressional debate about how best to curtail the problems within agriculture. 
Figure 5.1: Hearing Comparison Between Chambers

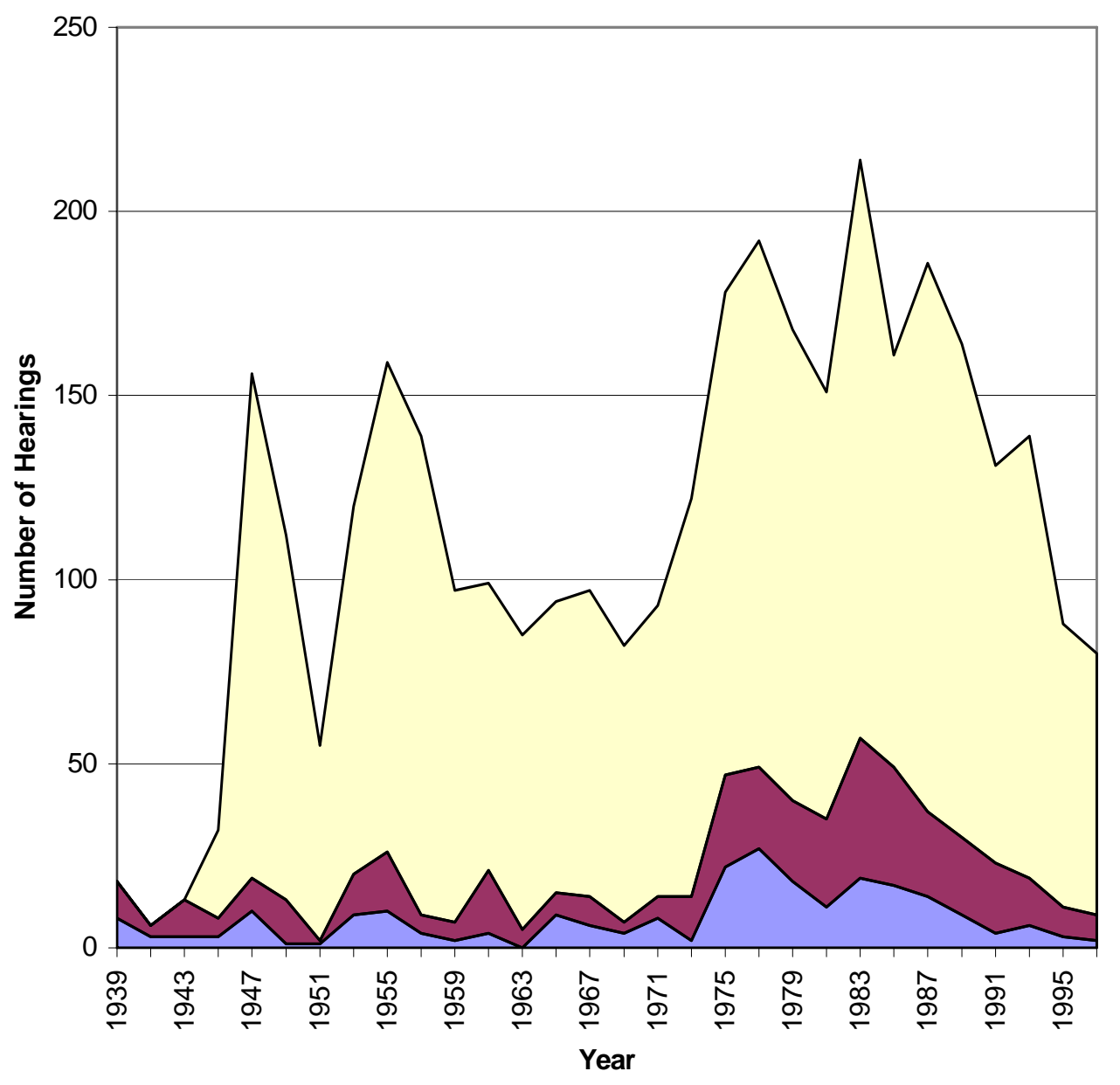

$\square$ Total number of Agricultural Hearings

$\square$ Credit, Insurance, and Income Hearings in the House

$\square$ Credit, Insurance, and Income Hearings in the Senate

\section{Policy Jurisdiction and Committee Competition}

To further explore the institutional changes associated with the aforementioned punctuating events, Figures 5.2 and 5.3 illustrate the degree of competition in both chambers. Both figures illustrate the percentage of the total number of hearings held by an individual committee across time. This presentation helps highlight the time frame in which different committees become active in influencing the agenda. In general, figures 
5.2 (House) and 5.3 (Senate) illustrate that the Agriculture Committees serve as the institutional bulwark of agriculture policy. However, as David King (1997) suggests, committee jurisdiction can be rigid and or flexible. Thus, there are instances in which the policy equilibria maintained by the Agriculture Committees varies. Both figures confirm the work of Baumgartner and Jones (1993), who indicate most punctuating events lead to an increase in committee competition

Figure 5.2: House Agricultural Hearings: Committee Competition

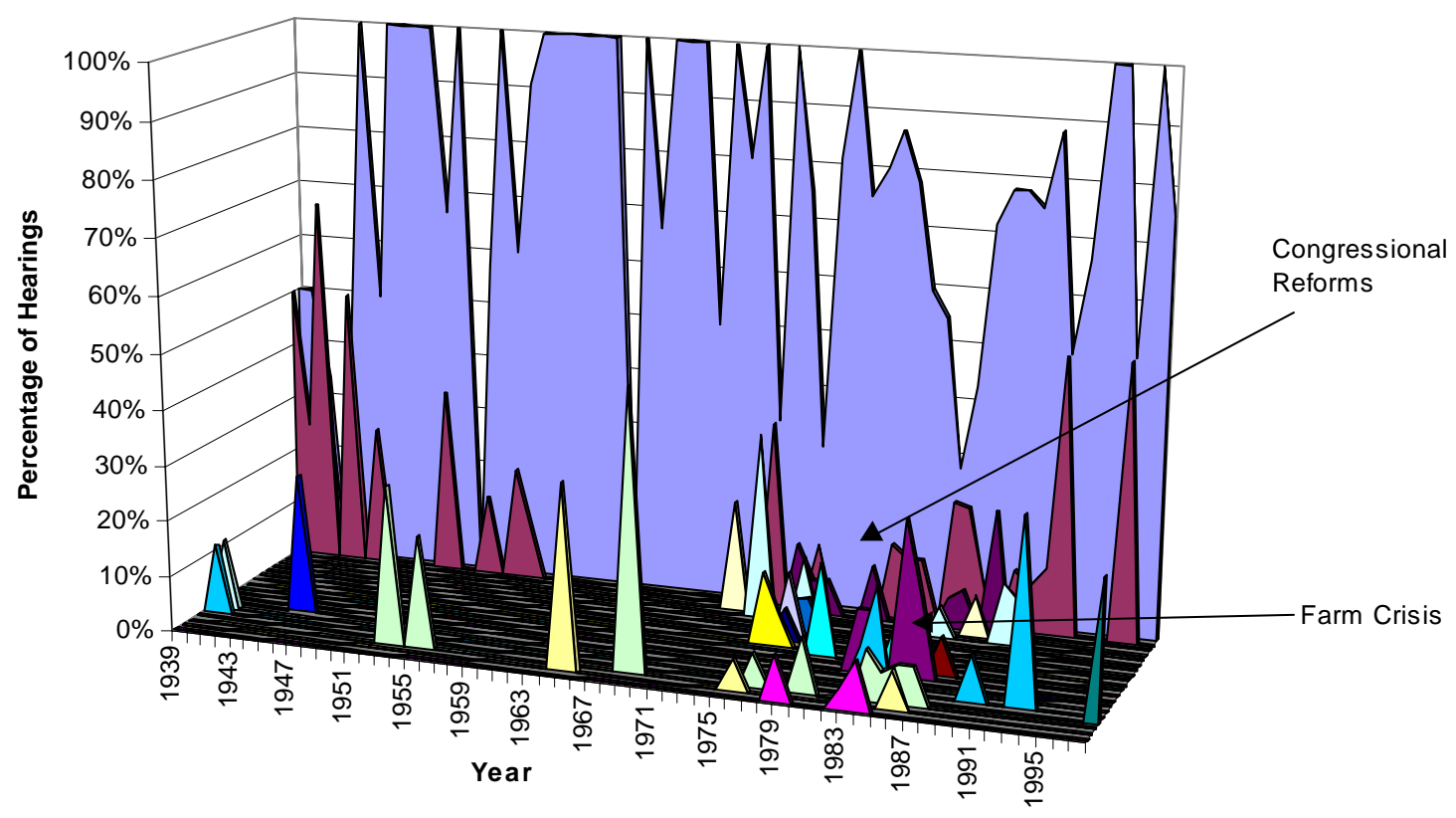

$\square$ Foreign Affiars

$\square$ Judiciary

$\square$ Energy

$\square$ Inter.Rel

$\square$ Small Business $\square$ Education \& Labor

$\square$ Public Works

$\square$ Science \& Tech.

$\square$ Post Office \&Civil Service

$\square$ Banking $\square$ Govt. Operations

$\square$ Flood

$\square$ Interstate \& Foreign Commerce

$\square$ Ways \& Means

$\square$ Agriculture $\square$ Govt. Reform

$\square$ Economic

- Merchant Marine

$\square$ Interior 
Figure 5.3: Senate Agricultural Hearings: Committee Competition

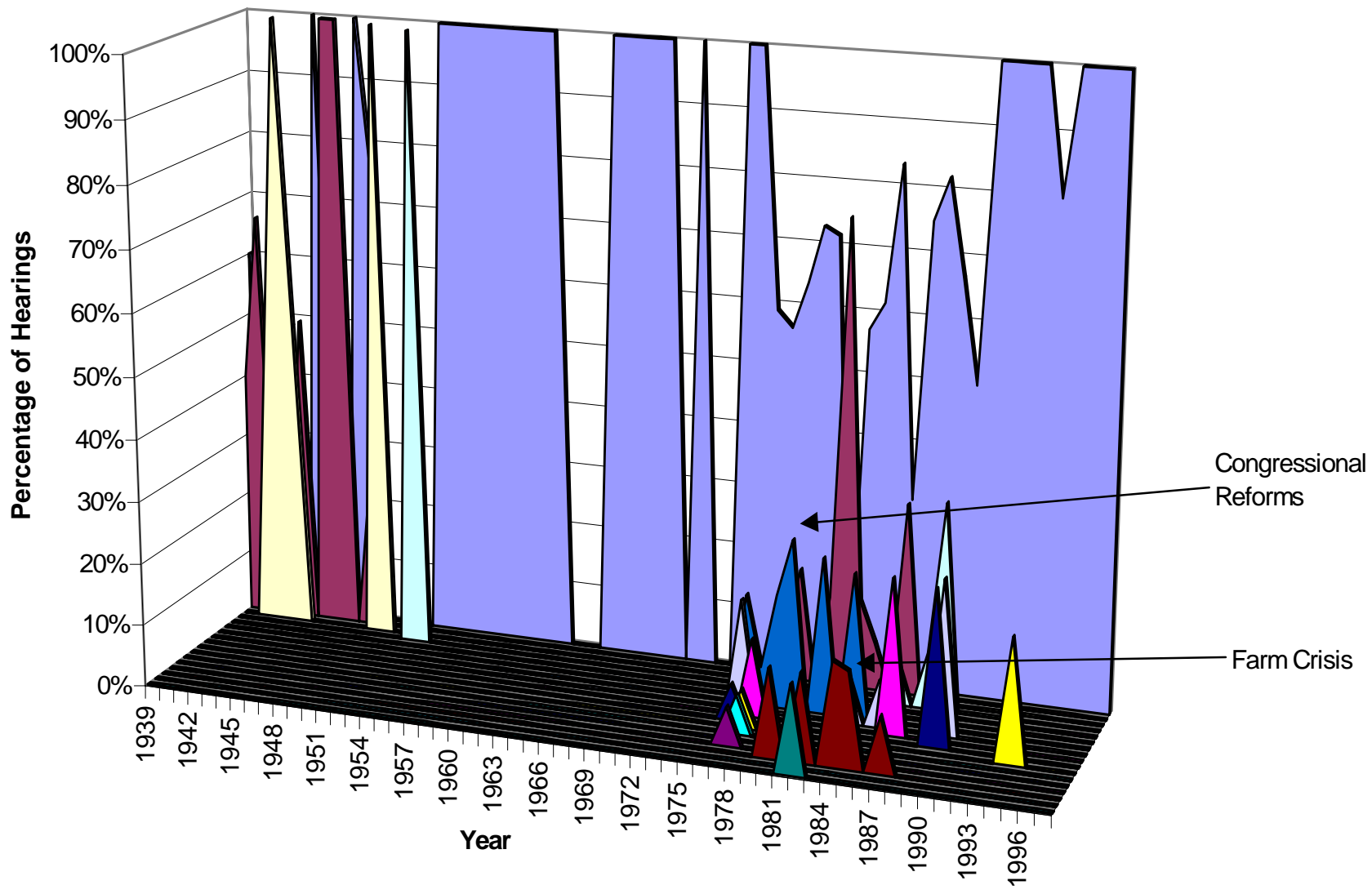

\begin{tabular}{|lllll|}
\hline$\square$ Government Affairs & $\square$ Budget & $\square$ Veterans Affairs & $\square$ Commissions & $\square$ Energy \\
$\square$ Interior & $\square$ Commerce & $\square$ Finance & $\square$ Small Business & $\square$ Labor \& Public Wel. \\
$\square$ Judiciary & $\square$ JC on Reduction & $\square$ Banking & $\square$ Agriculture & \\
\hline
\end{tabular}


Confirming the observations of Baumgartner and Jones (1993), Figures 5.2 and 5.3 illustrate committee competition increases during the reform era (1971-1977) and during the farm crisis in the mid 1980s. In 1976 the Agriculture Committee in the House held only $29 \%$ of the hearings, while over the previous decade it held over $80 \%$ of the hearings. Similarly, during the early and mid 1980s the policy debate involves ten different committees. In comparison, the Senate Agriculture Committee held 59\% of the hearings in 1976, whereas over the past two decades it held $100 \%$ of hearings.

Throughout the early and mid 1980s, the policy debate involved eight different committees attempting to determine the agricultural agenda.

This increased attention and the number of committees involved illustrates the argument of Cobb and Elder $(1972,35)$ who contend agenda setting, particularly the institutional agenda is routinely characterized by the degree of competition between sides. Attempts of various committees to determine the agricultural agenda throughout the mid 1970s and early 1980s demonstrates the increase in committee activity as described by Browne $(1995,7)$. Notably, the rise of competition during the reform and crisis period coincides with the committee competition present during the referral of bill introductions that was discussed in the previous chapter.

The punctuating events of the reforms and the farm crisis played an important role in the agenda of agricultural policy because it disrupted the policy subsystem and equilibria maintained by the Agriculture Committees. To buttress this point, Baumgartner and Jones $(1993,194)$ argue that when shocks and disruptions occur to the system, established policy subsystems can be vastly diluted. Aside from the disruptions caused by punctuating events to the system, the Agriculture Committees maintain a policy 
monopoly for a majority of the analysis—at least according to the hearings produced by the search. To illustrate the existence of the policy monopoly secured by the Agriculture Committees, Figures 5.4 (House) and 5.5 (Senate) contain Herfindahl index scores for each chamber. Both figures indicate the Agriculture Committees dominate the policy debate, but again during the congressional reform period and the era of farm crisis, additional committees attempt to govern the agricultural agenda.

Figure 5.4: House Herfindahl Index Score: Policy Monopoly

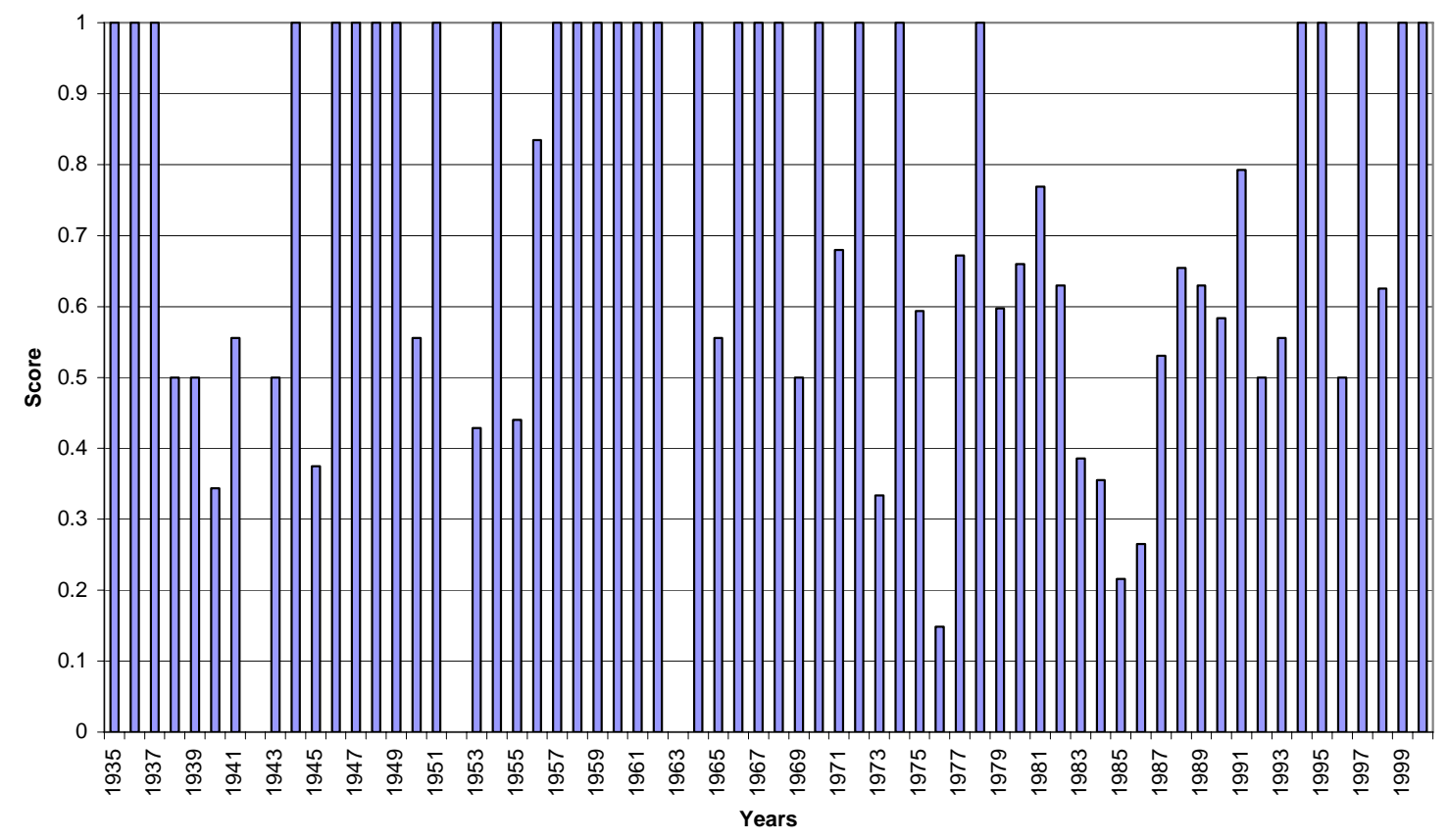


Figure 5.5: Senate Herfindahl Index Score: Policy Monopoly

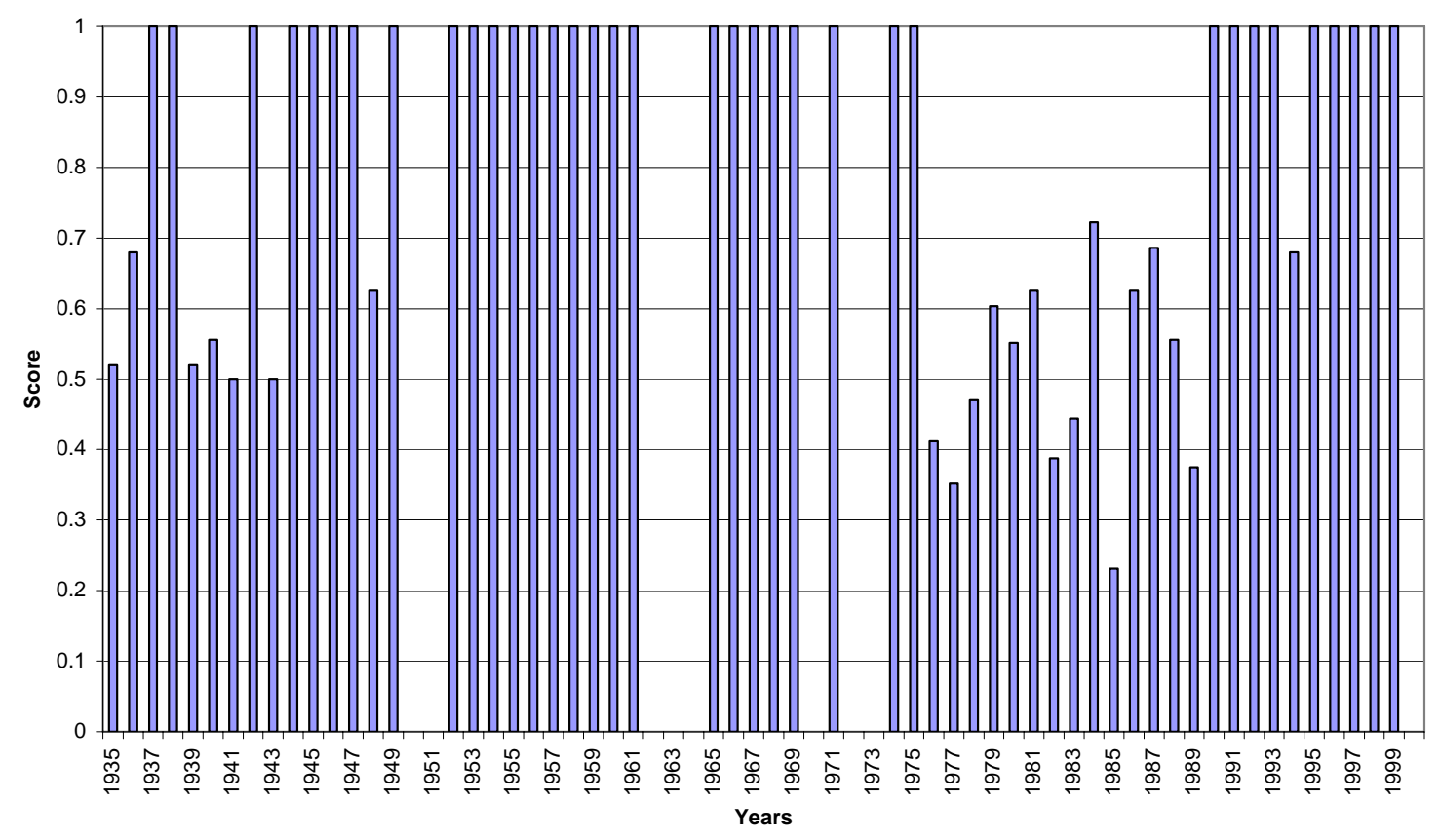

Hearing activity, as well as various committees attempting to influence the agricultural agenda occurred in accordance to shocks to the system. Thus, these punctuating events disrupted the equilibria maintained by the Agriculture Committees. When congressional attention is raised about a particularly issue, changes in the structures of policymaking typically follow suit (Jones and Strahan, 1985). When such changes arise, Baumgartner and Jones $(1993,194)$ state "previously uninvolved groups within and outside of the legislature are encouraged to participate; other groups, which had been dominant, are structured out of the issue, or they see their own influence vastly diluted” (194). With this in mind, the following section seeks to explore the witnesses who participate in the policy debate. In doing so, I am interested in examining whether 
the previously highlighted moments of punctuation result in the introduction of new interests in the policy process.

\section{Witness Participation: Who Participates in the Debate?}

As previously stated, the interests that appear at congressional hearings reflect the groups that members of Congress are likely to hear (Leyden, 1995). Likewise, the majority of groups that lobby Congress also testify at congressional hearings (Scholzman and Tierney, 1986). Therefore, determining the identity of interests appearing before Congress provides a portrait of the various interests seeking to influence the agenda in a particular policy realm.

\section{Witness Activity}

Identifying the witnesses present at hearings is accomplished through the use of the Congressional Information Service (CIS) Abstracts to Committee Hearings. The CIS Abstracts list the institutional or group affiliation of most witnesses. There are rare instances in which a witness appears from the local population with no clear institutional or group affiliation. Such witnesses are noted and coded as miscellaneous. The coding process distinguished between agricultural and non-agricultural witnesses. Furthermore, taking into account the primary concern of African American farmers, I also seek to ferret out any interest affiliated with civil rights. As such, witnesses are arranged into three separate coalitions_-agriculture, civil rights, and business/non-agricultural. The following indicates the witnesses that comprise each coalition. 
The Agriculture Coalition includes witnesses affiliated with the USDA, which consists of assorted bureaus and subunits such as the ASCS, FmHA, as well as the Department itself, agriculture interests groups—-which includes the National Grange, Farmers Alliance, Farmers Union, the American Farm Bureau Federation, various producer associations, cooperative associations (excluding The Federation of Southern Cooperatives), legislators from the Midwest and South, as well as individuals identified as "farmer" in the Abstracts. Although the interests arrayed within this coalition have conflicting/multiple interests, the rationale for categorizing them together follows previous research (Worsham, 2004; McCool, 1998; Lowi, 1964; Key, 1964) which suggests when a policy discussion turns redistributive in nature, those currently involved will seek to limit outsider access in hopes of protecting not only their share of the policy pie, but also their current seat at the agenda setting table.

In order to explicitly identify witnesses representing African American farmers and or individuals championing their interests, I thought it was important to create a Civil Rights Coalition. This particular coalition includes witnesses affiliated with various civil rights organizations and interests, southern church leaders, farmers identified as African American, Department of Justice personnel, representatives from 1890 Land-Grant Institutions, black farming interest groups, and agency personnel from the Farm Security Administration (FSA). As noted in Chapter Two, the FSA was included in this coalition because during the 1940s the agency effectively extended agricultural aid to black farmers (see Sheingate 2001; Franklin, 1942).

The third coalition created included a Business Coalition. This coalition was created because Brown $(1988,45)$ points out that business firms and banking interests regularly 
intervene in agricultural issues while attempting to circumvent agricultural subcommittees. Thus, this coalition includes witnesses associated with financial institutions (i.e. banking—not part of the farm credit system), and non-agricultural businesses and business interests such as the Chamber of Commerce, and multinational business firms.

In order to facilitate the analysis, the following section discusses witness participation in two subsequent ways. First, I examine the witnesses that dominate the agricultural debate and assess whether witness participation changes during the reform and crisis era—making note of any appearances made by civil rights interests. Second, and most important, I take a closer look at the various policy coupled hearings—detailing the issue discussed, the witnesses and or legislative entrepreneurs that testify, any legislation reported out, and any instructions that may have been given to the USDA.

\section{Discussion}

Overall, there were a total of 9,009 witnesses — (5,829 in the House and 3,180 in the Senate). In examining both figures 5.6 (House) and 5.7 (Senate), it is apparent that the agricultural coalition comprises the majority of witnesses appearing at the hearings from 1940 to 1998 . However as the figures illustrate, there are instances in which nonagricultural interests participate in the debate. For example, in both chambers business and civil rights interests appear between 1940 and 1948. Particularly, the emergence of business interests is understandable during this juncture considering the "role of the New Deal and World War II in focusing attention on the interrelationship between agriculture and business in righting the economy and aiding the war effort” (Worsham 2004, 8). To 
buttress this point, Zinn $(1997,310)$ suggests the WW II era was clearly characterized by business led cooperation and corporate profits. The civil rights interests that appear during this time reflect the support of the Farm Security Administration (FSA) seeking to secure funding for the Farm Tenant Act. Unfortunately for black farmers the FSA and the programs it administered was terminated by 1948. Civil rights interests appear again in the House in 1965 and 1967. In both years civil rights interests such as the National Association for the Advancement of Colored People (NAACP) appeared in support of the war on poverty programs for rural Americans that were being discussed in the Agriculture Committee. Although there was no direct mention of discrimination, the appearances of civil rights advocates suggest possible questions of inequality in the programs aimed at the agricultural poor. 
Figure 5.6 House Witnesses on Agriculture, 1940-1998

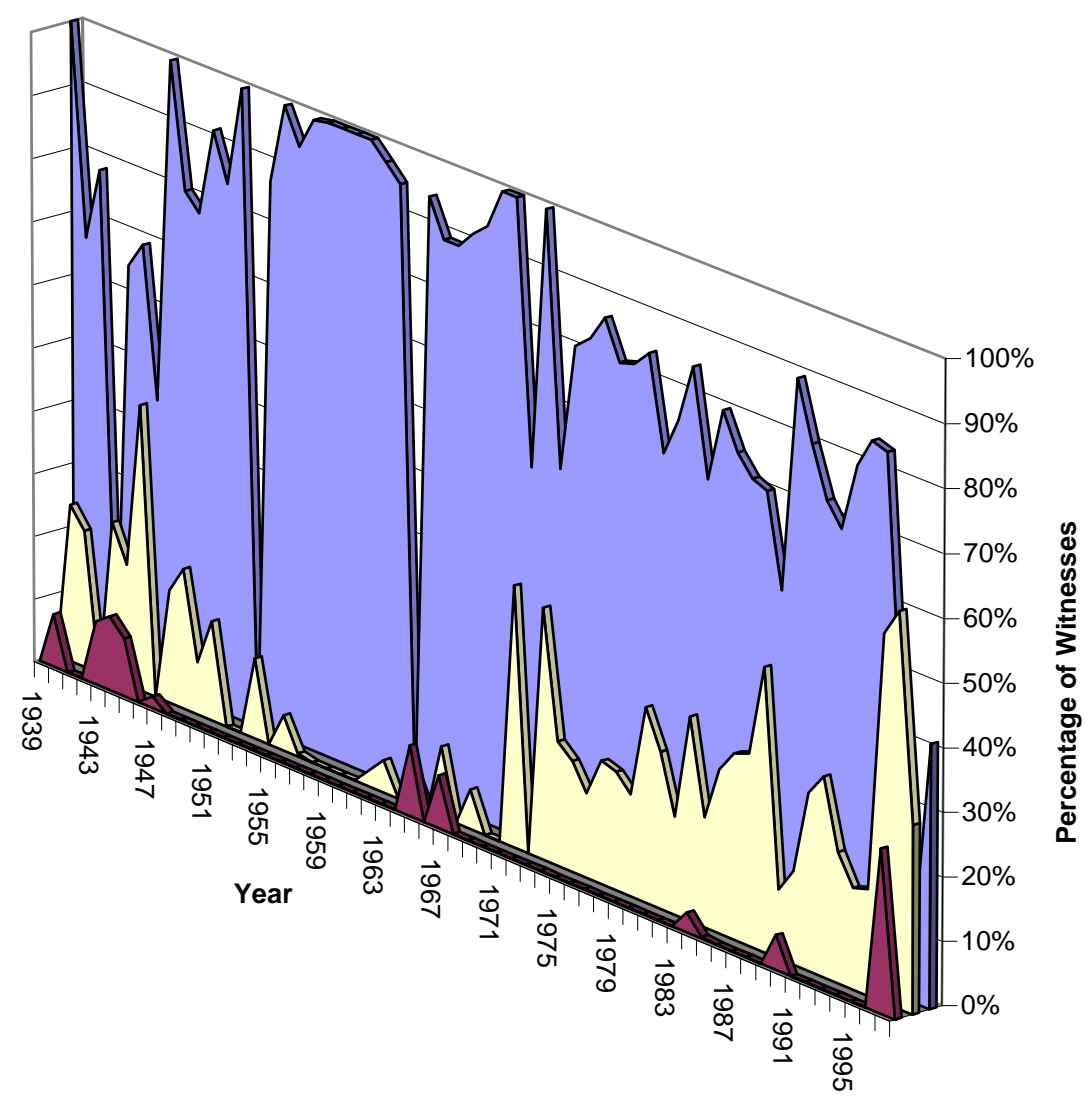


Figure 5.7 Senate Witnesses on Agriculture, 1940-1998

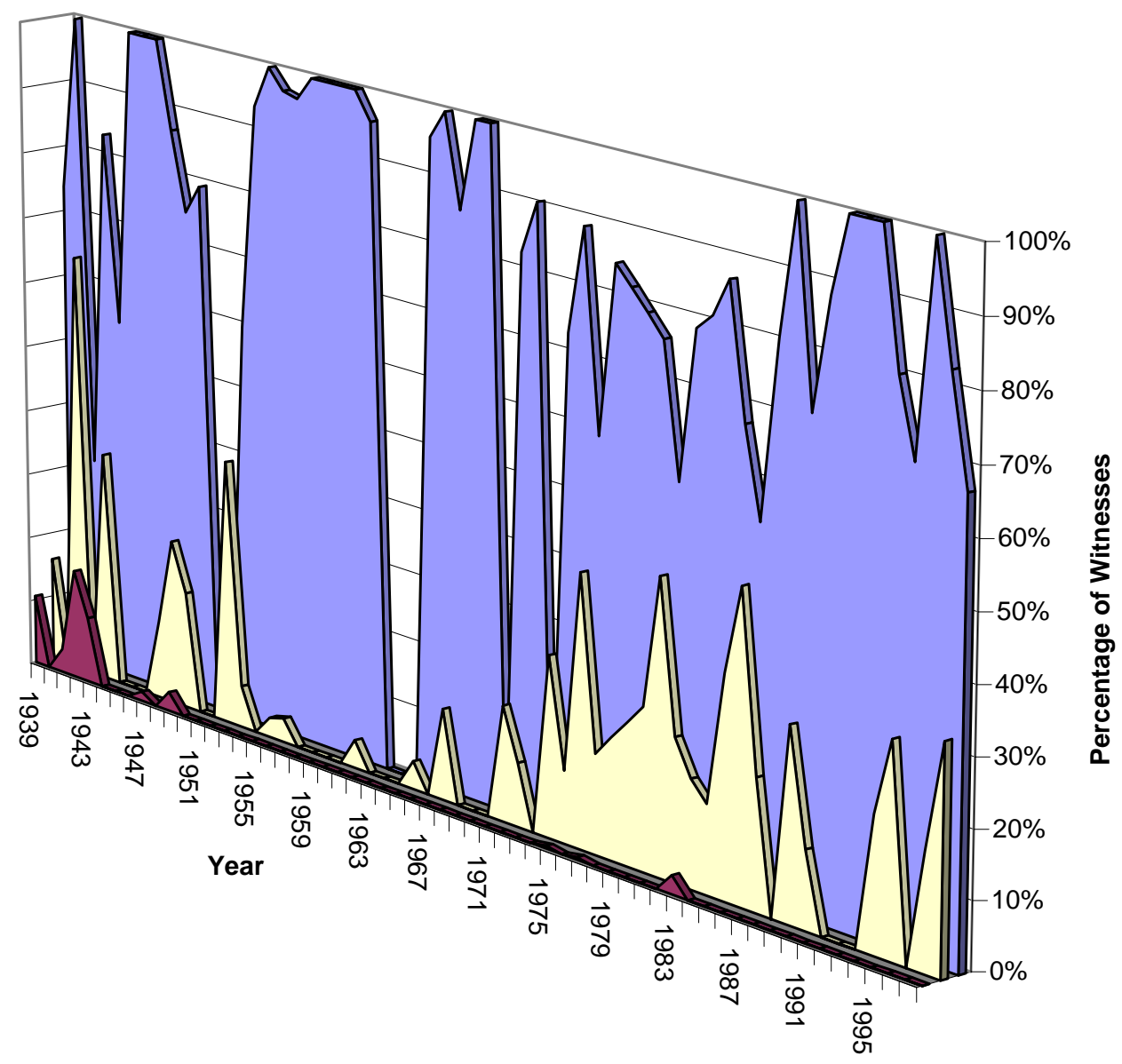

Not until the 1970s is there any discernable variation in the witnesses that appear before Congress. Again, agricultural interests dominate the debate, but business interests tend to enter the discussion, particularly during the reform and farm crisis era. On average between 1970 and 1989 business interests makeup approximately 35\% of the witnesses appearing at hearings in the House, while constituting $30 \%$ of witnesses in the Senate; whereas during the previous fifteen years, business interests on average constituted less than 5\% of witnesses appearing at hearings. Again, the increased period 
of competition that corresponds with the congressional reforms of the 1970s also appears to have opened the door to business appearances (Worsham 2004, 8). Particularly, the reforms of the 1970s not only decentralized power in standing committees (Lindasy 2002; Sheingate 2001; Baumgartner and Jones 1993) but it also appears to have loosened many subsystem alliances that had previously been established. As such, Sheingate (2001, 146) states, “farm legislation in the 1970s reflected a changing political environment in Congress: agriculture was losing its power to control the agricultural agenda.”

The business interests that emerged during the 1970s remained present throughout the 1980s. As argued throughout the research, when the booming agricultural conditions of the 1970s brought on by record level commodity prices, farm incomes, and farmland values collapsed, it was clear agricultural was not going to be as prosperous in the 1980s. In part, the effects of plunging crop prices, high interest rates, and declining agricultural exports helped kindle the farm crisis experienced from1981-1986. As Figures 5.6 and 5.7 indicate, there is small blip on the radar in which civil rights advocates appear during the farm crisis in both chambers, but again they comprise only a small fraction (less than 4\%) of the witnesses involved at hearings. However, one might suggest such appearances indicate efforts to redefine or at least debate agricultural policy in terms of civil rights-a topic I explore in the next section.

Notably, the problems experienced by the farming community due to the crisis also spilled over into the private sector, particularly for many banking institutions (aside from those of the farm credit system). At the peak of the farm crisis, banks failed across rural America at twice the rate that had been experienced during the later years of the 
Great Depression (Davidson 1996, 56). Considering the agricultural investments of the business community (specifically that of the 1970s), it was understandable as to why the business community became quite interested in the policy debate. This confirms the observation by Brown $(1988,45)$ that business interests readily look to intervene in congressional discussion about agricultural issues. In comparing Figures 5.2 and 5.3 (committee competition) to Figures 5.6 and 5.7 (witness participation) it is apparent when committee competition dies down in the late 1990s, the coalition activity of nonagricultural interests remain present and increases slightly. This indicates that the Agriculture Committees become more accommodating to previously excluded nonagricultural interests. This reinforces the observations of Browne $(1995,178,44)$ who suggests the 1990s was an era when the accommodation and introduction of new issues to the agricultural agenda was more prevalent.

\section{Policy Coupling: Debating Civil Rights and Agriculture}

In general, the previous discussion establishes that civil rights interests were periodically present during congressional discussions concerning agricultural support policy. However, evidence of an actual discussion of civil rights requires a closer look at those hearings. The following section details the various policy-coupled hearings and the corresponding committee's processing of civil rights. I begin this discussion by chronologically examining each policy-coupled hearing — which begins in the Senate and concludes in the House. 


\section{$\underline{\text { Farm and Home Foreclosures }}$}

On March 14, 1983 a nonlegislative hearing was held before the Subcommittee on Courts of the Senate Judiciary Committee. The hearing, chaired by Robert Dole (R-KS), examined the recent increase in farm credit and home mortgage defaults and foreclosures. ${ }^{21}$ David Miller, President of the Ohio Farm Bureau Federation, testified against any moratoriums on foreclosures, as well as any mandatory deferred payments of interest and principal for one year (Farm and Home Foreclosures, $98^{\text {th }}$ Cong., 1983, 6). Miller argued that such actions was harmful because borrowers that could make their payments may not make them and, because of this type of situation, use the money for other purposes (Farm and Home Foreclosures, $98^{\text {th }}$ Cong., 1983, 6). Miller argued that he opposed any kind of moratorium legislation because it encouraged and allowed people to unnecessarily take advantage of it. Instead, Miller noted that a better approach would be to improve the services of the FmHA. Specifically, Miller recommended that the FmHA revise their farm loan policies and procedures so they do not encourage loan deferral. Much of the debate by members of the agricultural coalition illustrated their disapproval of moratoriums and deferrals of interest.

The next witnesses to appear before the subcommittee included members from the civil rights coalition. Reverend Shearin Morris, Baptist clergyman from Betie, North Carolina and John Garland, Executive director for Legal Services of the Coastal Plains, testified that black farm owners in North Carolina were losing their farms due to the effects of racial discrimination. Mr. Garland noted that in the first congressional district in North Carolina, there was a 79\% decline in the number of black full-time farmers

\footnotetext{
${ }^{21}$ The argument could be made that the hearing in the Senate in 1983 was not necessarily indicative of policy coupling. However, the fact that individuals from the civil rights coalition discuss the issue explicitly in the context of racial discrimination and black farmers qualifies it for such designation.
} 
between 1954 and 1983 (Farm and Home Foreclosures, 98 ${ }^{\text {th }}$ Cong., 1983, 30).

"According to the North Carolina Division of Public Policy, [this] will mean by the end of the century there will be no black-owned farms in the state of North Carolina,” said Garland (Farm and Home Foreclosures, $98^{\text {th }}$ Cong., 1983, 30). Particularly, the brief testimony by Reverend Morris and John Garland was an attempt to debate home mortgages and farm foreclosures in the context of civil rights and discrimination. Considering the committee's lack of response to their testimony, it appeared as though their concerns fell on deaf ears. Although Morris and Garland may not have garnered immediate interest from the committee, Schattschneider (1960) suggests policy losers attempt to expand the scope of an issue in hopes of persuading non-participants to view the issue from their perspective. Perhaps this will occur, only time will tell.

The last panel of participants to testify included Frank Naylor, representing the USDA, Carl Fredrickson, representing the Farm Credit Administration, and James Jackson, board member of the Federal Home Loan Bank Board. In general, each witness outlined the various operations of the Farm Credit System, and detailed the causes of economic decline in the agricultural sector as it related to farm loan losses and foreclosures. Similar to the argument made by David Miller, Frank Naylor emphasized in his testimony that moratoriums and deferments would be counterproductive and harmful to the overall agricultural credit picture, and the ability and fairness of the farmers in the farming business (Farm and Home Foreclosures, $98^{\text {th }}$ Cong., 1983). Particularly, Carl Fredrickson asserted the best approach to strengthening agricultural income was by aggressively expanding export markets (Farm and Home Foreclosures, $98^{\text {th }}$ Cong., 1983, 89). James Jackson also opposed the idea of moratoriums because as he argued such 
provisions would unfavorably affect the national credit market, as well as individual savings. Overall, the hearing in the Senate and the debate over moratoriums and foreclosures overshadowed concerns of civil rights and discrimination. An interesting aspect about this hearing is the fact that no farmers suffering foreclosure were asked to testify, and moreover the hearing took place in the Judiciary Committee. This point illustrates that farm banks utilized the Judiciary Committee to avoid the interests of farmers supporting moratoriums; thereby limiting the supply of information as described by (Jones, Baumgartner, and Mare, 2005). A little more than a year would pass before the Judiciary Committee in the House became the venue where civil rights and agriculture were discussed.

\section{Civil Rights Enforcement Record of the Department of Agriculture}

On September 26, 1984 a nonlegislative hearing was held before the Subcommittee on Civil and Constitutional Rights of the House Judiciary Committee. The crux of the hearing chaired by Don Edwards (D-CA) focused exclusively on black farmers' access to credit under the FmHA farm credit programs. Of the ten witnesses that appeared, nine represented the interests of black farmers, while Alma Esparza, director of the Office of Equal Opportunity, represented the USDA.

The witnesses from the civil rights coalition opened by criticizing the USDA's rural lending program by alleging that the FmHA had discriminated against minority applicants by refusing to process their loan applications for federal funding. Witnesses such as Jeanine Kleimo, with the Housing Assistance Council, indicated to the committee that the presence of more minorities in loan-making positions would help lessen the sense 
of intimidation felt by many minority borrowers who apply for Farmers Home programs (Civil Rights Enforcement Record of the Department of Agriculture, 98 ${ }^{\text {th }}$ Cong., 1984, 6). Probably the most profound testimony came from Timothy Pigford, a farmer who was representing concerned farmers of North and South Carolina. Pigford's testimony illustrated the problems he and other black farmers experienced trying to operate a farming business that must deal with the effects of discrimination. Pigford explained to the committee that due to the fact that many black farmers specialize in only one crop, the occurrence of a drought would wipe out a farmer's income, which consequently prohibits he or she from paying back their loans (Civil Rights Enforcement Record of the Department of Agriculture, $98^{\text {th }}$ Cong., 1984) Pigford added that unfortunately the FmHA has "continuously denied farmers the credit or the funding to go and invest in areas to make a better crop” (Civil Rights Enforcement Record of the Department of Agriculture, $98^{\text {th }}$ Cong., 1984, 82). Adding to Pigford's argument was Representative George Brown (D-CA) who provided testimony criticizing the USDA's inadequate and failed attempts to enforce civil rights compliance. “The Farmers Home Administration, one of the largest sources of civil rights complaints, is in no position to enforce civil rights compliance,” said Brown (Civil Rights Enforcement Record of the Department of Agriculture, $98^{\text {th }}$ Cong., 1984, 86).

Alma Esparza, Equal Opportunity director of the USDA, sought to curtail the negative onslaught against the USDA by pointing out how the USDA's initiatives to comply with civil rights laws have always been understood by the agency. Esparza testified that the USDA was making conscious steps to comply with all civil rights regulations, including efforts to encourage minority employment. Esparza stated that the 
employment of minorities has increased 15.2 percent from 1980 to 1983 . And while additional steps need to be taken, Esparza asserted efforts are already underway (Civil Rights Enforcement Record of the Department of Agriculture, 98 ${ }^{\text {th }}$ Cong., 1984, 98). In general, Mr. Esparza’s testimony sought to debunk allegations of discrimination by highlighting the institutional mechanisms and procedures in place seeking to promote justice and equality within the FmHA.

The last panel of witnesses, also from the civil rights coalition, included the president from the Emergency Land Fund, a representative from the Rural Study Group, and two different attorneys. Notably, the witnesses continued to reiterate allegations of discrimination and inequities of the FmHA's assistance to black farmers-particularly against black farmers in Alabama. Joseph Brooks, president of the Emergency Land Fund contended that the FmHA practice of making grossly inadequate loans to black farmers created a general pattern of disparity in the lending practices between black and white farm applicants (Civil Rights Enforcement Record of the Department of Agriculture, $98^{\text {th }}$ Cong., 1984, 139). Brooks suggested throughout his testimony that as long as the the FmHA continued to encourage delinquent black farmers to sell their land, a positive and supportive relationship could not be developed between the two parties.

The competition that had shaped up between civil rights advocates and the sole representative of the USDA was a one sided debate-dominated chiefly by the interests supporting black farmers. The hearing illustrates that it is outsiders who first try their hand at combining civil rights with agricultural policy. Such attempts highlight how various individuals from the civil rights coalition functioned as policy entrepreneurs driven by their values and ideology about influencing the shape of policy as described by 
Kingdon (1995). In addition, the Judiciary Committee’s accommodation of civil rights interests illustrates the observations by King $(1997,143)$ that jurisdictional fragmentation allows access points for groups to pursue their policy endeavors. Thus, the hearing for black farmers was not only a time to disclose allegations of discrimination, but it was a venue to garner support against the decline of black farmers. As important as the discussion may have been, Congress did not hold additional hearings on the issue until the summer of 1990 .

\section{Decline of Minority Farming in the U.S.}

On July 25, 1990 a nonlegislative hearing was held before the Government Information, Justice, and Agriculture Subcommittee of the Committee on Government Operations. The hearing chaired by Robert Wise (D-WV) mirrored that conducted by the Judiciary Committee in the sense that it also focused on allegations of discrimination by the FmHA. The first to testify at the hearing was Congressman Mike Espy (D-MS). Espy vehemently explained the FmHA had been consistently discriminating against black farmers in Mississippi for over the past decade and without change black farmers will continue to face such injustice. Espy asserted the USDA had turned a blind eye and allowed the FmHA to routinely deny agricultural credit to minority farmers solely on the grounds of race. Espy argued without continued oversight the FmHA would continue to operate in an inefficient and discriminating fashion. "Once efforts have made to eliminate the problem, I think it is important for efforts to be continually maintained to guard against [discrimination] in the future," said Espy (Decline of Minority Farming in the U.S., 101 ${ }^{\text {st }}$ Cong., 1990). 
Testimony by four other supporters for black farmers also railed against the FmHA by testifying how the agency had been unresponsive to Freedom of Information Act requests regarding discrimination complaints. Advocates justified their claims by introducing the Commission on Civil Rights 1982 report, which criticized the USDA's treatment of black farmers. Advocates pointed to the report's discussion of occurrences of credit discrimination by local FmHA officials in North Carolina, Alabama, and Mississippi. David Harris, Executive Director of the Land Loss Prevention Project, discussed accounts of discrimination by the FmHA. Harris provided documented cases where local offices of the FmHA refused to process applications, blatantly refused to agree to any restructuring agreements, denied farmers extra copies of various loan documents, and readily badmouthed minority farmers that came into the office for assistance. Such allegations presented by Harris and other members of the civil rights coalition clearly identified the FmHA as a haven for discrimination. Advocates suggested the USDA should not only aggressive investigate activity of inequality, but also remove those employees responsible for discrimination.

Coming to the succor of the USDA was La Verne Ausman, administrator of the FmHA and Evelyn White, acting director for the Office of Advocacy and Enterprise. Both witnesses testified in defense of the FmHA's loan, training, and technical assistance programs. They explained the FmHA is charged with assisting family farmers who are unable to obtain needed credit from commercial lenders at rates and terms they can afford (Decline of Minority Farming in the U.S., $101^{\text {st }}$ Cong., 1990). Ausman suggested without their services many small-scale farmers would have a very difficult time obtaining any credit at all. Both Ausman and White reiterated throughout their testimony how the 
limited resource farm operating program and the targeted loan program are two programs that have and will continue to be beneficial in assisting socially disadvantaged, minority farmers.

Interestingly enough, the testimony by Ausman and White was basically a presentation of the programs available to all farmers. Neither witness sought to confirm the allegations brought forth by Harris’s testimony. In fact, their testimony repudiated any agency wrong doing concerning loan disbursement. To illustrate this point, Ausman stated, "A look at our loan activity shows loans are disbursed among minorities in a pattern generally matching the farm population” (Decline of Minority Farming in the U.S., $101^{\text {st }}$ Cong., 1990, 172). Overall, the hearing in 1990 was significant because it provided a forum to discuss agricultural policy and the USDA in terms of civil rights. This is significant because this hearing as well as that held by the Judiciary Committee, illustrates the agenda setting option "encourage it to happen,” referenced by Ripley (1985). Under this particular option government provides groups access to define problems so that the policymaking process does not consistently displace less affluent interests. Unfortunately this access was short-lived. It would be seven years before another hearing was held explicitly examining the USDA's treatment of black farmers.

Treatment of Minority and Limited Resource Producers by the U.S. Department of Agriculture

On March $19^{\text {th }}, 1997$ a nonlegislative hearing was held before the Subcommittee on Department Operations, Nutrition, and Foreign Agriculture of the Committee on Agriculture. Previously, civil rights and agriculture were debated in the Judiciary and Government Operations Committees, now discussions are occurring within the 
agricultural domain. The hearing sought to examine allegations of USDA agricultural credit discrimination against black farmers. First to testify before Chairman Bob Goodlatte (D-VA) was Robert Robinson, director of Food, Agriculture Issues and Economic Development of the General Accounting Office (GAO). Contrary to the claims of discrimination made by black farmers, Robinson's testimony was less critical of the actions of the USDA.

Specifically, Robinson's testimony presented the findings from a report by the GAO titled "Efforts to Achieve Equitable Treatment of Minority Farmers." In describing the purpose and findings of the report, Robinson explained that the records of the FSA from 1995-1996 did not illustrate a pattern of discrimination as argued by many advocates for black farmers. After referencing various statistical figures and percentages documented in the report, Robinson concluded his testimony with an assertion that most black farmers would refuse to agree with. "Despite the higher disapproval rates for minority farmers, decisions to approve or disapprove applications were supported by information in the files. And FSA staff appeared to apply decision-making criteria to minority and non-minority applicants in a similar fashion,” said Robinson (Treatment of Minority and Limited Resource Producers by the U.S. Department of Agriculture, $105^{\text {th }}$ Cong., 1997, 7). Although Robinson struggled to answer various questions posed by the committee concerning the issue of loan discrimination, he refused to waver on the findings of the GAO’s report.

The GAO report presented by Robinson was rejected by the testimony by David Harris Jr., Executive Director of the Land Loss Prevention Project. Harris introduced information from the 1982 report of the United States Commission on Civil Rights, 
which highlighted the inequitable delivery of services by the USDA against minority farmers. Overall, Harris’s testimony highlighted the discriminating acts and practices committed by FSA employees in local offices in North Carolina and Mississippi. Harris continued to reiterate that discrimination has been the primary cause for the decline in African American farmers. The detailed testimony by Harris introduced solutions to address the problems of discrimination and neglect. Such recommendations included strict regulations to compel local officials to obey the law, adequate and equitable outreach to all black farmers, and sanctions to all USDA employees who fail to uphold these standards (Treatment of Minority and Limited Resource Producers by the U.S. Department of Agriculture, $105^{\text {th }}$ Cong., 1997). Harris concluded his testimony by urging Congress to require the USDA to monitor its civil rights performance on a scheduled and routine basis.

On July $17^{\text {th }}$ the hearing resumed with testimony from Secretary of Agriculture, Daniel Glickman, and Lloyd Wright, a representative from the USDA Office of Civil Rights. At the outset, the chairman stated discrimination by the USDA could not and would not be tolerated. Glickman asserted it was the policy of the USDA that every farmer should have fair and equal access to all federal programs administered by the USDA (Treatment of Minority and Limited Resource Producers by the U.S. Department of Agriculture, $105^{\text {th }}$ Cong., 1997, 94). Both Glickman and Wright responded to the chairman's opening statements by testifying that the agency has been working to address all forms of discrimination against USDA employees and minority farmers (Treatment of Minority and Limited Resource Producers by the U.S. Department of Agriculture, $105^{\text {th }}$ Cong., 1997, 95). Glickman also indicated that a three-person panel was used to 
investigate all alleged reprisals and make binding recommendations when warranted. When asked about the discrimination of loan processing, Glickman responded, "I've also ordered that loan processing continue on accounts where a discrimination complaint is pending. Standing up for your rights should not disqualify someone from seeking a farm loan” (Treatment of Minority and Limited Resource Producers by the U.S. Department of Agriculture, $105^{\text {th }}$ Cong., 1997, 95). Mr. Wright also responded to the chairman's question regarding discrimination by indicating that the USDA was in the process of hiring economists and investigators to determine the consistency of discrimination experienced by black farmers, and to what extent they had been hurt by USDA policies. Glickman and Wright's testimony highlighted the administrative steps and actions made by the USDA to address allegations of discrimination and inequality. As such, their testimonies not only implicated the USDA, but it validated the claims of discrimination made by black farmers over the past decade.

Last to testify at the hearing was Congresswoman Maxine Waters (D-CA) and Congressman John Conyers (D-MI). Both expressed their frustration with the USDA, calling for immediate measures to resolve the numerous complaints of credit discrimination. Waters argued for a system of guidelines intended to "get these claims out of the way and off the books, and we need to do [so] very aggressively” (Treatment of Minority and Limited Resource Producers by the U.S. Department of Agriculture, $105^{\text {th }}$ Cong., 1997, 124). At one point during the hearing Congresswoman Waters had gotten so abrasive with one of her statements that the chairman had to ask her not to continue with the interjection. Notably, Representative Conyers acknowledged his concern in the issue by requesting the committee hold a hearing where only members of the farm 
communities that have been subjected to discrimination appear to testify. Conyers advocated efforts to not only protect, but also strengthen the minority farming community. Conyers suggested to the committee that without congressional assistance African American farmers will continue to disappear (Treatment of Minority and Limited Resource Producers by the U.S. Department of Agriculture, $105^{\text {th }}$ Cong., 1997).

The hearing that took place in the Agriculture Committee was significant because it signaled the importance of an issue and, it also illustrated how legislative entrepreneurs, Maxine Waters and John Conyers sought to define agriculture in terms of civil rights. As described by (Wawro, 2001; Fenno, 1973) the efforts of Waters and Conyers highlight their motivation for "good public policy” aimed at addressing discrimination against black farmers. Legislative entrepreneurs utilize relevant information to learn about existing policy and to push forward policy recommendations in that area (Wawro, 2001; King, 1997). As such, the hearing allowed Maxine Waters and John Conyers the opportunity to express the importance of devising a new system to address all unsettled claims of discrimination.

\section{Civil Rights Legislation and Other Issues}

On October 23, 1997 the House Committee on Agriculture held a legislative hearing to consider proposals H.R. 2185 and H.R. 2692. H.R. 2185 introduced by Eva Clayton (DNC), sought to protect the civil rights of black farmers by revising the structure of the FSA county committees. H.R. 2692 introduced by chairman of the committee Bob Smith (R-OR), primarily looked to combine the FSA and the NRCS into a single agency within the USDA. In addition, it also included provisions regarding discrimination against 
socially disadvantaged farmers. Notably, the importance of this hearing is the fact it is occurring within the subsystem.

As was the case earlier, first to testify was Secretary of Agriculture, Daniel Glickman. He began by expressing his support to resolve all sources of discrimination against African American farmers, arguing that the presence of more women and minorities on state committees, along with the resolution of some 350 employment discrimination complaints, was proof that the USDA was serious about discrimination. "The bottom line is that we have taken just about all the administrative actions we can to improve our civil rights record. It's gotten us off to a good start, but we have not completed the course,” said Glickman (Civil Rights Legislation and Other Issues, $105^{\text {th }}$ Cong., 1997, 47). After explaining the new administrative policies intended to root out discrimination, Glickman argued against combining NRCS and the FSA into a single agency within the USDA. Specifically, Glickman testified that the USDA was currently in the midst of some very dramatic changes related to the 1994 Reorganization Act, and another layer of change would be detrimental to the agency’s ability to effectively implement federal farm programs. Glickman argued that America’s farmers and ranchers need a strong Natural Resource Conservation Service and a strong Farm Service Agency. Glickman asserted that both agencies perform critical and unique functions, which should not be mashed together (Civil Rights Legislation and Other Issues, $105^{\text {th }}$ Cong., 1997, 48). In general, Glickman's testimony illustrated how the USDA resisted having to undergo the organizational changes suggested by either proposal.

Gerald Vap, President of the National Association of Conservation Districts, who represented the National Association of State Conservation Agencies, supported 
Glickman's testimony arguing that both bills cloud the distinct mission of each agency. Vap suggested it was paramount the USDA maintain a separate and distinct natural resources and environment mission area because it helps farmers, ranchers and others meet their land management needs in an environmentally responsible manner (Civil Rights Legislation and Other Issues, $105^{\text {th }}$ Cong., 1997). Aside from expressing discontent with both proposals—particularly H.R.2692, Vap’s testimony commended Secretary Glickman's progress to improve the efficiency and effectiveness of the USDA. Lawrence Lucas, President of the USDA Coalition of Minority Employees, also opposed the organizational changes included in H.R. 2692. Lucas explained the Act did not provide the Secretary the authority to immediately remove those employees who had been discriminating in administering farm credit programs, nor did it allow changes in counties where discrimination was a problem (Civil Rights Legislation and Other Issues, $105^{\text {th }}$ Cong., 1997). Specifically, Lucas felt the Act lacked the teeth necessary to fundamentally address the issue of discrimination. As Lucas saw it, additional organizational changes would only make a bad situation worse.

The final panel of witnesses to testify represented the interests of African American farmers. Various witnesses such as David Harris, Executive Director of the Land Loss Prevention Project, presented information summarizing the multitude of issues and problems hindering the civil rights compliance and enforcement by USDA agencies. The most interesting aspect of Harris's testimony was his criticism of Chairman Smith's proposal-H.R. 2692. As indicated, Smith’s proposal primarily involved merging the NRCS and the FSA into a single agency within the USDA. In addition, there were also provisions in the Act intended to benefit socially disadvantaged farmers. In his 
presentation, Harris asserted that the substitute language in Smith’s proposal in essence undercut the authority of the Office of Civil Rights and limited the Secretary's discretion in developing effective mechanisms to address civil rights issues. In part, the points made by Harris basically mirrored the argument made by Lawerence Lucas.

Representatives from the Black Farmers Agriculturalist Association (BFAA) and the National Black Farmers Association (NBFA) thanked Congresswoman Eva Clayton for her proposal to address the issue of discrimination, suggesting bipartisan support was needed to truly address the issue (Civil Rights Legislation and Other Issues, $105^{\text {th }}$ Cong., 1997, 104). The hearing concluded with Gary Grant, BFAA president, and John Boyd, NBFA president expressing their concern over the loss of black-owned farms (Civil Rights Legislation and Other Issues, $105^{\text {th }}$ Cong., 1997, 108).

The hearing held on October 23, 1997 within the agricultural subsystem, clearly illustrates the top-down theory of agenda setting and government policy. This approach to agenda setting views major policy initiatives, recommendations, and challenges deriving from government officials and policy communities (Studlar, 1990; Anderson, 1984). For example, proposals to reorganize the USDA originated from members within the agricultural domain, and resistance to these proposals was expressed from the policy community—primarily those who felt disadvantaged by the reorganization. In addition, legislative action to restructure the USDA highlights the "make it happen” option of agenda setting referenced by Ripley $(1985,107)$. As attempted by Eva Clayton and Bob Smith, policymakers play an active role in setting goals and defining policy proposals. 


\section{Discussion}

Each of the policy-coupled hearings presented illustrate the efforts to define agricultural policy in terms of civil rights. For the most part, the three different committees that held policy-coupled hearings discussed agricultural support policy in relation to the discrimination black farmers experienced from the FmHA in applying for agricultural credit. The subtle variation that exists in comparing these hearings is not so much the chamber or which committee holds the hearing, as it is the type of hearing being held. In terms of witness participation, the single (policy coupled), bill-referral hearing held by the House Agriculture Committee tended to be slightly more balanced in the selection of witnesses than the other four nonlegislative hearings. For example, as indicated in Table 5.1, the bill-referral hearing in 1997 during the $105^{\text {th }}$ Congress illustrates that of the eleven witnesses testifying, five represented the interests of black farmers. In contrast, the nonlegislative hearing also held during the $105^{\text {th }}$ Congress by the House Agriculture Committee before the Subcommittee on Department Operations, Nutrition, and Foreign Agriculture illustrates that of the ten witnesses that testifying, eight represented and or supported the interests of black farmers.

Table 5.1: 1997 Policy-Coupled Hearings: Witness Comparison

\begin{tabular}{|c|c|c|}
\hline Witnesses & $\begin{array}{c}\text { (1997) Legislative Hearing } \\
\text { H.R. 2185 \& H.R. 2692 }\end{array}$ & (1997) Non-legislative Hearing \\
\hline Agriculture & 6 & 2 \\
\hline Civil Rights & 5 & 8 \\
\hline
\end{tabular}


Although this is only one illustration it does confirm the conclusions of Talbert, Jones and Baumgartner $(1995,392)$ who argue in most instances bill-referral hearings are typically more balanced in terms of the witnesses that testify. In contrast, "committee leaders [more readily] stack the list of witnesses in nonlegislative hearings to ensure that a certain viewpoint is heard” (Talbert, Jones, and Baumgartner 1995, 401).

When analyzing the period of congressional reforms (1971-1977) and the farm crisis (1981-1986) neither punctuating event necessarily resulted in the introduction of civil rights advocates appearing at hearings. Aside from the policy coupled hearing in the Senate in 1983 and the House in 1984, continued debates about civil rights and agricultural policy occurred primarily in the 1990s—specifically in 1990 and 1997. Particularly, in 1997 during the $105^{\text {th }}$ Congress, the civil rights coalition in the House comprised $26 \%$ of witnesses showing up at hearings (see figure 5.6). This marginal percentage change is pertinent because during the six previous years (91-96) civil rights advocates did not appear at any of the hearings. More than likely this increase is due to the fact the influential class-action lawsuit by black farmers was filed approximately six months prior to the start of the $105^{\text {th }}$ Congress (1997-1998). Couple this with numerous "listening sessions" on discrimination held by the USDA around the country throughout 1995-1997 and consequently the level of attention increases, thus spurring additional civil rights advocates to enter the fray. And while the punctuating events of the congressional reforms and the farm crisis may not have opened the door to civil rights advocates, such events did however disrupt the policy equilibria maintained by the Agriculture Committees and as a result triggered corresponding legislation. 
When comparing the levels of hearing activity surrounding the moments of punctuation between 1975 and 1991, we see it corresponds to major pieces of agricultural legislation. As illustrated in Figure 5.8, the significant peak in hearing activity in the $95^{\text {th }}$ Congress is accompanied by the Agricultural Act of 1977. A key element of the Act revised and expanded the food stamp provisions, which eliminated the purchase requirement and simplified eligibility requirements. This provisional accommodation was in part the effects of bipartisan cooperation inspired by the changing of the old southern guard — which was brought on by the congressional reforms (Ernstes, Outlaw, and Knutson, 1997). Particularly, the food stamp provision was important to many congressional urban liberals. However, inner-city districts and farm districts were both outnumbered by suburbanites in Congress, thus without bipartisan cooperation of an urban-rural coalition, food stamp and farm programs would not exist (Hansen 1991, 210). 
Figure:5.8: Hearing Activity and Agricultural Legislation

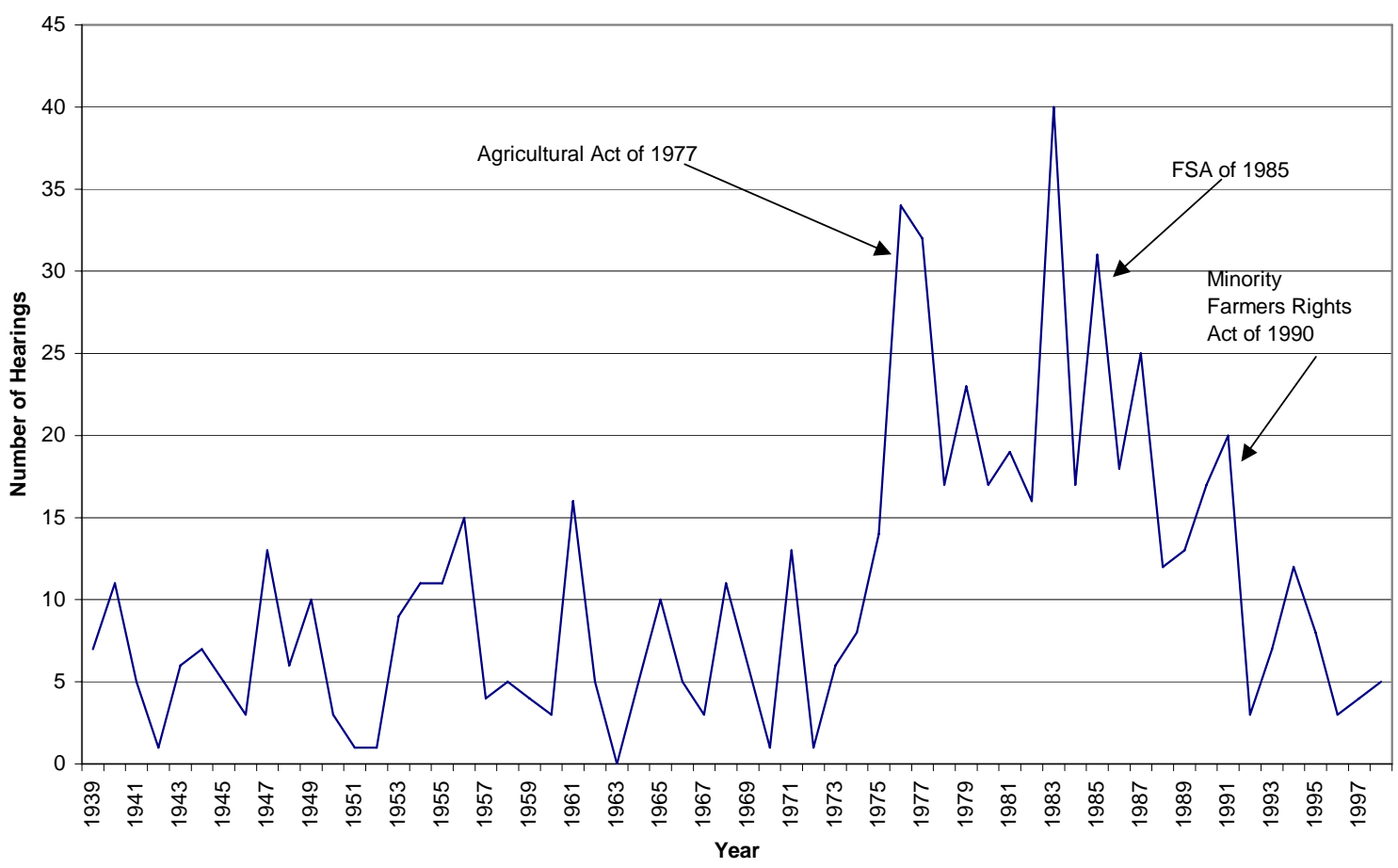

In addition, the surges in hearing activity in the early 1980s also resulted in the Food Security Act of 1985. As previously described throughout previous chapters, both the House and Senate Agriculture Committees during the early 1980s readily introduced bills and held hearings centered on addressing the adverse effects of the farm crisis. Particularly, agricultural policy was forced to the forefront of the federal budget debate (Cochrane and Runge, 1992). The primary result of such institutional activity directed Congress to curtail the crisis by trimming farm subsidies and stimulating farm exports. Although not due to a particular punctuating event, the small peak in hearing activity in 1990 is also accompanied by the Minority Farmers Rights Act. This small rise in activity implicitly illustrates the suggestions by (Sheingate, 2001; Browne, 1995) that agricultural policy during the $101^{\text {st }}$ Congress had come to mean more things to more people and as a 
result was more inclusive. Taking this into consideration along with the increasing number of discrimination complaints might lead to one to say the soil of the agricultural agenda was fertile for the entrepreneurial efforts of Mike Espy, Wyche Fowler and The Federation of Southern Cooperatives to plant seeds of policy change.

\section{Conclusion}

Agenda setting can at times be competitive and dynamic. Subsystems function in this process by restricting the number and variety of interests involved in policymaking, thereby limiting access to an otherwise pluralistic endeavor. However, depending upon the events that take place and or the participants seeking to institute change, policy equilibria can be disrupted. The level of congressional attention and debate given to agricultural policy of special concern to African American farmers is relatively limited over time. At the start of the mid 1970s (during the congressional reforms) and throughout the mid 1980s, (the era of the farm crisis) the level of activity peaks, but tails off by the late 1980s and reverts back to the status quo. Such change in activity is indicative of negative feedback as described by Baumgartner and Jones (1993).

In addition, the policy monopoly secured by the Agriculture Committees in both chambers and the agricultural coalition that tends to dominate the policy debate, lends support to the presence of subsystem politics in the development of agricultural support policy. But, just as punctuating events resulted in an increase in hearing activity, such events also led to the accommodation of non-agricultural interests-particularly those connected with financial institutions and multination corporations. Yet it appears that 
local activism, a growing number of discrimination complaints, the efforts of policy entrepreneurs, and the class action lawsuit brought against the USDA all worked together to open the door for civil rights advocates to explicitly debate agricultural policy in the context of civil rights. In part, the lawsuit in itself signaled a change in venue from the legislative domain to that of the judicial arena. This in essence marked a shift from seeking congressional attention to the hopeful beginning for judicial redress.

In sum, the symbolic, yet under-funded step taken by Congress in 1990 with the Minority Farmers Rights Act was significant to black farmers, but the claims of discrimination continued to emerge; not to mention the reports indicating how African American farmers continued to decline (Wood and Gilbert, 2000). Particularly, the congressional gain made by black farmers in 1990 and the overall increase of the issue in 1997 was in part the effects of the activities promulgated at a different venue level—the state and local level, and while problems continued to persist, the issue was taken to a third venue-the court. Thus, the next chapter seeks to highlight the group pressue that took place at the state and local level, the movement of the issue into the court, and why the current status of the issue still remains indefinite. 


\title{
6
}

\section{The Last Toil for Redress}

\author{
Justice delayed is justice denied \\ -Attributed to William E. Gladstone
}

In the previous chapters I asserted the agenda of agricultural support policy was not conducive to the interests of black farmers over the post-war period. The preliminary evidence from the bill introductions indicate the agenda between civil rights and agriculture remain relatively disjointed in terms of policy content/description. Even though the apex of activity between both policy areas is similar, this similarity does not equate to policy coupling and subsequent legislation until 1990. Illustrating that prior to 1990, dominant subsystem politics, antagonistic agricultural policy, and the effects of discrimination made it difficult for black farmers to succeed in the realm of agriculture.

The policy monopoly maintained by the Agriculture Committees and the policy equilibria maintained by Congress were disrupted by both endogenous and exogenous events. The stimuli associated with these events produced change in hearing activity, as well as witness composition. Moreover, the periods in which hearing activity and witness composition varied, bill introductions varied also; suggesting that the stimuli brought forth a change in hearing activity and is plausibly responsible for the change in bill introductions.

The attempt in 1990 to inject civil rights into the discussion of agricultural policy was in part successfully accomplished through the energy and collaborative efforts of interests groups, policy entrepreneurs, and a changing agricultural agenda. This chapter 
seeks to understand how energy was generated by group pressure at the state and local level. This discussion will illustrate how group pressure at the local level served as a venue for success in bringing forth change at the national level. However, in light of the limited success achieved on the congressional front and the continued complaints of discrimination, black farmers soon moved the issue to the venue of the courts. The chapter concludes by examining the Pigford v. Glickman lawsuit and the lingering remnants of the case.

\section{Groups Pressure the USDA}

While change slowly occurred at the congressional level, success would not have been realized without activism at the state and local level. Various church leaders, farming groups, individual actors, and civil rights and farming interests opposed the USDA's discriminatory actions toward African American farmers. Borrowing a page from the 1960s, protests, marches, sit-ins and speeches were all held in response to the USDA's unfair treatment of the minority farming community. Just as the civil rights protests in Albany, Georgia and Birmingham, Alabama in the early 1960s increased attention to the inequality of minorities (Gilbert and Eli, 2000; Chong, 1991), black farmers also took similar measures to demonstrate their will to cultivate governmental action.

The first of several actions occurred in 1981 when a group of approximately 25 black individual farmers staged a 23-day sit-in at a local USDA office in Tipton County, Tennessee. The action was in support of black farmers who had been denied or delayed operating loans by local offices of the USDA. As important as the sit-in was to black farmers in Tennessee, it failed to initiate any governmental action. However, according to 
the findings of the Civil Rights Commission, the 23-day sit-in proved to be warranted. Notably, the entrepreneurial actions of the Civil Rights Commission studied the problem in 1982, and indicated black farmers waited far longer for loan decisions and were more likely to be rejected for loans than their white counterparts. In addition, investigators also found $84 \%$ of white applicants had their loan applications approved, while only $56 \%$ of black applicants were granted approval (Mitall and Powell, 2000, 4). This discovery illustrated that the organizational culture of the USDA was indicative of what Wilson $(1989,76)$ describes as client politics.

The 1990s was an important decade for African American farmers. Not only did the Minority Farmers Rights Act emerge during this juncture, but as previously discussed, there were several congressional hearings held discussing the issue of discrimination and agricultural credit as well. During this dynamic era of the 1990s, black farmers refused to remain quiet; instead they continued to publicly protest their frustration with discrimination and land loss by black farmers, and the government's unwillingness to address the issue. Brown (2003) suggests that during the 1990s, several black farm interest groups such as the Federation of Southern Cooperatives/Land Assistance Fund (FSC/LAF), the National Black Farmers Association (NBFA), and the Black Farmers an Agriculturalist Association (BFAA) were influential in orchestrating the protest rallies highlighting the discrimination by the USDA.

Probably the most active of these groups was the FSC/LAF. The FSC/LAF, which was originally known as the Federation of Southern Cooperatives forged in the early 1960s during the Civil Rights Movement. The mission of the Federation was to protect and expand the landholdings of black farmers in the South, and to develop, advocate and 
support public policies aimed at benefiting black and low income farmers in rural communities (http://www.federationsoutherncoop.com; Gilbert and Eli, 2000; 163). In 1985 after merging with the Emergency Land Fund, a sister organization that also sought to protect black landownership, the new organization, called the Federation of Southern Cooperatives/Land Assistance Fund (FSC/LAF) was established.

The NBFA and BFAA are also two influential groups that represent the interests of black farmers. The NBFA was founded in 1995 by president, John Boyd Jr. The mission of the organization is to eliminate and reverse the causes of land loss experienced by black farmers (www.blackfarmers.org/main.htm). Similar to the FSC/LAF, the NBFA advocates policies seek to improve access to agricultural credit for small-black farmers. Also forming in the mid-1990s was the BFAA. The BFAA is a non-profit organization that was established in 1997 to respond to the issues and concerns of black farmers in the U.S. and abroad (http://bfaa-us.org). In addition to advocating policies and programs aimed at strengthening the black farming community, the BFAA was also organized to monitor the USDA and the Pigford v. Glickman class action lawsuit. Overall, the mission and policy goals of the FSC/LAF, the NBFA, and the BFAA are the same-to protect, support, and strengthen the minority farming community.

In September of 1992, the Federation of Southern Cooperatives/Land Assistance Fund (FSC/LAF) and several other black farmers organized a Caravan for Justice to Washington, DC. Activists marched and protested at the U.S. Capitol and at the U.S. Department of Agriculture in concern to the discrimination that continued to exist in the delivery of USDA programs (Smith and Hoff, 1997). Receiving little attention, black farmers remained steadfast and organized another rally four years later. On December 12, 
1996, the National Black Farmers Association (NBFA), and the Federation of Southern Cooperatives/Land Assistance Fund (FSC/LAF) held marches and rallies at the USDA's Jamie Whitten Building in Washington, D.C. (Wood and Gilbert, 2000, 58). The groups were protesting racial discrimination by the Farm Services Agency (FSA), which had recently consolidated two earlier agencies—-the FmHA and the Agricultural Stabilization and Conservation Service (Wood and Gilbert, 2000, 58). Unlike previous demonstrations, this event received considerable media attention (Brewer, 2003, 14; Wood and Gilbert, 2000, 58).

In response, USDA Secretary of Agriculture Dan Glickman appointed a Civil Rights Action Team (CRAT) of USDA officials to hold "listening sessions" throughout the country to get input from the public—particularly minority farmers and USDA employees concerning civil rights issues facing the USDA in both program delivery and employment (Smith and Hoff, 1997). The eleven coast-to-coast listening sessions held by CRAT were well attended, but yet tumultuous and highly critical of the USDA's program delivery (Brewer, 2003). Notably, Secretary Glickman or Deputy Secretary Richard E. Romancer attended all but one of the sessions; in part their attendance "gave the meetings elevated status and high visibility in order to counter previous negative publicity about USDA indifference (Browne, 2003, 145).

On Friday, February 28, 1997, the CRAT released their report, entitled "Civil Rights at the U.S. Department of Agriculture.” The report stated, in part:

Minority farmers have lost significant amounts of land and potential farm income as a result of discrimination by FSA programs and the programs of its predecessor agencies, ASCS and Amah. Socially disadvantaged and minority farmers said USDA is part of a conspiracy to take their land and look to USDA for some kind of compensation for their losses (Civil Rights Action Team, 1997, 30). 
The CRAT came back to Washington criticizing the USDA's Civil Rights Division for having a backlog of over 900 discrimination complaints (Civil Rights Action Team, 1997). Several departmental officials asserted the backlog was due to staffing and funding issues, and constant reorganization of the civil rights office (Brewer, 2003). Despite the defense by departmental officials, Secretary Glickman sided with the report by the CRAT. As such, he admitted to the USDA's long history of racial discrimination, and vowed to change the department (Wood and Gilbert, 2000, 59). As part of Glickman's quest to institute change, he set a deadline of six months for implementation of the 92 recommendations contained in the CRAT's report (Smith and Hoff, 1997). However, due to the increasing number of discrimination complaints, several black farmers, led by Timothy Pigford of North Carolina, filed a class-action lawsuit against the USDA in August of 1997 (Wood and Gilbert, 2000, 59).

\section{Order from the Court}

As previously indicated, the CRAT concluded that racial discrimination had been rampant throughout the USDA for many years. The report suggested the racial disparities in disapproval rates for loans and processing times, lack of diversity on county committees, and ineffective civil rights complaint system all plagued the USDA (Wood and Gilbert, 2000). When the USDA failed to implement its own 92 recommendations, African American farmers turned their attention to the Court in hopes of having their problems of discrimination addressed.

In 1997, thousands of black farmers consolidated their complaints against the USDA and filed the largest class-action lawsuit in history, Pigford \& Brewington. v. Dan 
Glickman, Secretary, the United States Department of Agriculture (Civil Action No. 971978, PLF, and 98-1693, PLF) (Brewer, 2003; Wood and Gilbert, 1997). The lawsuit claimed the USDA had discriminated against black farmers in denying operating and disaster loans, and other forms of assistance between 1983 and 1997 (Browne, 2003, 145). At the end of 1997, President Bill Clinton met with John Boyd, president of the National Black Farmers Association (NBFA), to seek a resolution of the class-action lawsuit. In response, Congress eventually passed a bill extending the statute of limitations in the case beyond the typical two years. Unfortunately no meaningful settlement ever materialized.

Subsequently, in August of 1998, approximately 250 black farmers gathered in Alabama for the FSC/LAF's $31^{\text {st }}$ annual meeting (Rubinstein and Dookhun, 1998). The meeting announced plans for a pilgrimage to Washington, D.C. to support claims of discrimination and express frustration with the outcome of Boyd and Clinton's meeting the previous year. In December of 1998, John Boyd and members of NBFA followed through with their plans by holding a march in front of the White House-complete with tractors and a mule. The protest marked the one-year anniversary of the farmer's continual grass-roots battle against more than three decades of documented discrimination by the USDA and its employees (Smith, 1998).

By mid-September, 1999, approximately 15,000 black farmers had joined the class-action settlement (Wood and Gilbert, 2000). On October 9, 1999, Judge Paul Friedman certified the Pigford class, allowing the case to carry forward as a class action lawsuit (www.ewg.org/reports/blackfarmers/part2.php). The major struggle in closing the case involved the structure of the potential settlement. Through the process of mediation, 
involved parties debated whether to settle all of the farmers' claims or structure the agreement solely on the basis of arbitration. After much debate and several extensions of the filing deadlines, the parties finally entered into a resolution for settling the case in 1999. The dispute resolution mechanism formed involved a two-track process. Track A awarded \$50,000 tax-free. This track was designed to provide quick limited relief for farmers with minimal documentary proof. Track B was an evidence-based proceeding to recover actual damage. This track was put in place to offer an abridged trial procedure for farmers who had an overwhelming degree of documentation supporting their claim of discrimination. This process was designed to take a maximum of approximately eight months, from claim submission to decision. Farmers choosing this track had the burden of proof criteria, “preponderance of the evidence,” in proving their case. On April 14, 1999, Judge Paul Friedman signed the consent decree authorizing two separate tracks for redress (www.ewg.org/reports/blackfarmers/part2.php).

Not all were happy with the consent decree. Several class members, civil rights organizations and farmer organizations such as the FSC/LAF, NBFA, and the BFAA were clearly unhappy with the resolution mechanism. Overall, the Court received objections from 15 organizations and 27 individuals, including the two named plaintiffs-Timothy Pigford and Cecil Brewington. Complaints centered on the recovery amount, the structure of the resolution, and the lack of forward-looking relief. Farmers were concerned that the resolution did not look to explicitly address discrimination within the USDA. Notably, the USDA did not include any language in the consent decree indicating that all attempts would be made to prohibit discrimination in the future. As such, farmers were not only concerned with holding the USDA accountable of their 
discriminatory actions, but they also wanted to institute change that would ultimately change the culture of the institution. Otherwise, farmers had reason to believe discrimination would persist.

The Court reviewed the objections and agreed the settlement was fair and efficient in addressing the farmer's grievances. The Court's reasoning for the amount awarded under Track A was that most farmers lacked sufficient evidence to prove their claims and "the settlement negotiated by the parties provides for relatively prompt recovery compared to a trial, where, it is unlikely any class member would have received any recovery for his injury for many years” (Pigford, 1999, 104-105). In essence, the Court embraced the idea it was better for farmers to have their grievances partially met, than not at all. With this in mind, Baum (1997) might ask the question whether the Court is more concerned with policy or legal clarity. It appears as though the Court's rationale for upholding the decree was not exclusively an issue of legality, but rather an option to institute the most expeditious policy outcome. To buttress this point, the Court reasoned the settlement was fair because the "USDA is obligated to pay billions of dollars to African American farmers who have suffered discrimination and those billions of dollars will serve as a reminder to the Department of Agriculture that its actions were unacceptable and should serve to deter it from engaging in the same conduct in the future" (Pigford 1999, 111). Aside from banishing discrimination on legal grounds, the Court signaled its desire that the USDA institute policy aimed at addressing and curtailing further occurrences of discrimination.

In examining Table 6.1, approximately $40 \%$ of the 21,982 farmers whose claims were reviewed under Track A were denied. Of the 182 who filed cases under Track B, 
only 18 were awarded compensation. Moreover, there were an additional 72,000 claims that were not reviewed by arbitrators, because they were filed too late (Fears, 2004). After admitting guilt in 1999, five years later, the USDA is recanting its admission of discrimination by fervently contesting thousands of claims at all costs. Again, the report by Environmental Working Group (EWG) concluded three quarters of the \$2.3 billion agreed to in Pigford had not been paid, and almost nine out of every ten claimants had been denied, some on such technicalities as incorrect spelling. As of 2004, black farmers and their attorney James Myart, Jr. were granted a preliminary motion by a U.S. District Court where the group hopes reconsideration for the 80,000 denied claims will be achieved. 
Table 6.1: Pigford v. Veneman: Consent Decree in Class Action Suit by African American Farmers: (As of July 9, 2003)

\begin{tabular}{|c|c|}
\hline Claims reviewed under consent decree & 23,229 \\
\hline $\begin{array}{l}\text { Claims accepted by facilitator for } \\
\text { processing in Track A }\end{array}$ & 21,982 \\
\hline $\begin{array}{l}\text { Information from USDA submitted to } \\
\text { adjudicator }\end{array}$ & 21,782 \\
\hline $\begin{array}{l}\text { Information from USDA not yet submitted } \\
\text { to adjudicator }\end{array}$ & 200 \\
\hline $\begin{array}{l}\text { Claims accepted by facilitator for } \\
\text { processing in Track B }\end{array}$ & 182 \\
\hline $\begin{array}{l}\text { Claims rejected by facilitator for } \\
\text { processing (not class member) }\end{array}$ & 1,065 \\
\hline \multicolumn{2}{|l|}{ TRACK A: } \\
\hline Adjudicator’s determinations completed & 21,590 \\
\hline Rulings against claimant & $8,480(39.3 \%)$ \\
\hline Rulings in favor of claimant & $13,110(60.7 \%)$ \\
\hline $\begin{array}{l}\text { Eligible to receive } \$ 50,000 \text { payment from } \\
\text { Department of Justice }\end{array}$ & 12,995 \\
\hline $\begin{array}{l}\$ 50,000 \text { payments made to claimant by } \\
\text { Department of Justice: (Total amount paid) }\end{array}$ & $12,831(\$ 631,550,000)$ \\
\hline $\begin{array}{l}\text { Claimants with loans identified for } \\
\text { cancellation: (Total number of loans) }\end{array}$ & $1,307(3,443)$ \\
\hline $\begin{array}{l}\text { Claimants with loans identified for } \\
\text { cancellation which still had a balance } \\
\text { owed: (Total number of loans) }\end{array}$ & $221(451)$ \\
\hline $\begin{array}{l}\text { Claimants whose loans were cancelled: } \\
\text { (Total amount cancelled) }\end{array}$ & $221(\$ 18,453,280)$ \\
\hline $\begin{array}{l}\text { Claimants who received an offset refund: } \\
\text { (Total amount refunded) }\end{array}$ & $61(\$ 206,227)$ \\
\hline
\end{tabular}

Information documented from the United States Department of Agriculture: Pigford $v$. Veneman Class Action Suit. 
In 2002, the National Association for the Advancement of Colored People (NAACP) held a conference in hopes of increasing political awareness of African American land loss. ${ }^{22}$ The conference which brought together black farmers and land owners, NAACP members from various state-level branches, agricultural extension agents, representatives from universities and state-level agricultural agencies and others, sought to raise public awareness and develop a course of action to stop the decline of African American land loss and to educate African American landowners of their rights (Black Issues in Higher Education, 2002). Items of importance discussed during the conference included the importance of building coalitions with various organizations, informing and educating black voters about land loss issues, and the importance of collaborating with historically black colleges and universities—considering their important role of training students for careers in agriculture (Black Issues in Higher Education, 2002).

One might suggest that the conference held by the NAACP was an attempt to expand the civil rights coalition by appealing to the policy core beliefs of other organizations. Sabatier and Jenkins-Smith $(1999,122)$ state that policy core beliefs are inherently important to a coalition because they "represent basic normative and empirical comments within the domain of specialization of policy elites.” Considering policy core beliefs are less rigid and more flexible (Sabatier and Jenkins-Smith, 1999, 122), coalitional expansion is more feasible, and as result influencing policy outputs is strengthened. Thus, the conference by the NAACP not only served to bolster awareness

\footnotetext{
${ }^{22}$ The conference was held at Tuskegee University, which was titled, "Shadow Lands: Empowering the African American Farmer and African American Landowner.” The conference was sponsored by the NAACP as part of the organization's voter empowerment agenda.
} 
about the problems facing black farmers, but it also functioned as a strategy to spawn an advocacy coalition.

In addition, in July of 2002, black farmers from Tennessee, Georgia, North Carolina, Oklahoma, Arkansas, Mississippi, and Alabama took part in a "Prayer Vigil and Non-Violent Sit-In” at the USDA’s Farm Services Agency (FSA) office in Brownsville, Tennessee (Muhammad, 2002). The five-day sit-in, similar to that held twenty-one years earlier in 1981, was in support of black farmers across the nation who had been discriminated against by the USDA. The main purpose of the sit-in was to attract public and media support, and ultimately congressional support for the establishment of a "separate but equal” lending agency specifically for African American farm borrowers (Muhammad, 2002). By attracting media attention, participants of the sitin attempted to revive issue salience on the public agenda and once again spur action at the congressional level. Dearings and Rogers (1996, 74-75) note that such efforts are important because they can impact the agenda setting process. For the most part, the majority of grassroots activity in the early 1980s was orchestrated primarily by the FSC/LAF, and by the mid to late-1990s groups such as NBFA and BFAA emerged to bring greater attention to the issue and to strengthen efforts of mobilization and group solidarity. 


\section{Conclusion}

The pursuit for civil rights and justice for African American farmers has been a long contentious journey. Despite the passage of the Civil Rights Act of 1964, black farmers continued to experience discrimination and inequality by the same agency intended to address their needs - the USDA. In 1862 when President Abraham Lincoln founded the USDA he called it the "peoples Department.” Unfortunately this motto did not always ring true for black farmers. Attempts to bring about policy change by influencing the agricultural agenda were hindered due to the work of American governing institutions and the politics of institution building (Browne 2003, 130). This exemplifies the “don't let it happen” option of agenda setting, in which institutions function along side groups and participants who seek to limit particular problems from gaining institutional access (Ripley, 1985, 107).

Currently the Court has become the primary venue for black farmers hoping to have their immediate needs addressed. After achieving short-term and limited success in Congress in 1990, farmers concluded the Court would be the institutional means for redressing the actions of the USDA, but considering the USDA's avoidance of responsibility and the on-going process of the lawsuit, hopes for redress are indefinite. Therefore, as described by Rosenberg (1991), only time will tell whether a "dynamic view” of the Court is realized and ultimately maintained. As of today, the jury is still out concerning whether black farmers will truly receive their “40 acres and a mule,” which was promised to them over one hundred years ago. 


\title{
Concluding Comments
}

\author{
"Institutions are typically designed to encourage \\ participation by certain groups and discourage \\ participation by others." \\ -Frank Baumgartner and Bryan Jones $(2002,24)$
}

I began this study with three objectives. First, is to understand how Congress governs the agenda of agricultural support policy over the post-war period. Second, to learn whether such governing is conducive to the interests of African American farmers, and third, to gain insight on whether the agenda of agricultural support policy ever intersected with civil rights. In seeking to accomplish these objectives, I have utilized three qualifiers: (1) congressional committees as the venue of focus, (2) bill introductions and (3) hearings as the measures of agenda status and governmental attention. Congressional committees were chosen because committees are the cornerstone of the political process, as well as the anchor for subsystem arrangements (Worsham, 2004; Fiorina, 1989). Thus, as most studies of agenda setting affirm, it is an appropriate venue to examine the political evolution of any policy (Baumgartner and Jones, 1993).

So what does the research say about agenda setting, agricultural support policy, and African American farmers? First, the research confirms the observations of most scholars who assert agenda setting is a dynamic and inherently political process. In the case of my research, participants at the table of agenda setting are predominately those interests closely allied with the institutional venue in which the policy resides. 
For example, the Agriculture Committees serve as the bastion for policy and the agricultural coalition that is accommodated tends to dominate the policy debate. As such, the agricultural coalition functions primarily as a "dominant coalition."

Worsham $(1998,488)$ suggests, "policy produced in a dominant coalition setting favors select interests over the public interests.” As such, civil rights advocates were primarily on the outside looking in, when trying to influence the agenda. When the policy equilibria maintained by the dominant coalition is disrupted by punctuating events, the emergence of previously excluded interests enter the fray—particularly that of business interests. In addition, punctuating events also lead to the policy outcome (i.e. legislation) of 1977 and 1985. The Agriculture Committee in the House is most accommodating to civil rights advocates when the institutional level of attention concerning black farmers and discrimination are elevated. Likewise, the Minority Farmers Rights Act of 1990 emerged as the result of policy entrepreneurs responding to local level complaints. Thus in part, not only do punctuating events serve as a catalyst for policy disequilibria, but the stimulus generated by interest group pressure is also a contributing factor.

Considering the aforementioned factors, is the agenda of agricultural support policy of special concern to African American farmers characteristic of a top-down or bottom-up approach to agenda setting? To claim the process of agenda setting operates solely in one direction would be an inaccurate assessment of most agenda setting studies. Rather, the process wavers and moves back and forth between both approaches. In doing so, the changes that occur can happen incrementally and in bursts, and when the bursts take place, the old ways of doing things are replaced by new organizational forms (Baumgartner and Jones, 1993, 235). Thus, when considering the occurrence of various 
punctuating events, this process characterizes the agenda of agricultural support policy. Aside from the Minority Farmers Rights Act of 1990, the agenda of agricultural policy is rarely conducive to public interests - that of black farmers. This is primarily because the congressional management of the agenda and the majority of policy produced consistently reflected the values held by the dominant agricultural interests, and the relationship formed with allied interests. Notably, when change occurs from the collaboration of bottom-up interest group pressure and the actions of legislative entrepreneurs, negative feedback counterbalances the system, thus bringing the policy equilibrium back to the status quo. From this perspective, the agenda of agricultural support policy and the system in which it operates is characteristic of negative feedback as noted by Baumgartner and Jones (1993).

Aside from the approach that has been taken in this study, there are certainly other venues and perspectives to explore which would be useful for future research. For example, this research would have benefited from a detailed analysis of subcommittees. Considering the effects of the congressional reforms, this analysis would have helped highlight the influence that various subcommittees may have had on policy changes (Baumgartner and Jones, 1993, 202). In addition, examining the actions of the Congressional Black Caucus (CBC) in relation to policy-coupling and legislative entrepreneurs would illustrate the caucus’ attempts at challenging the agricultural subsystem.

At the macro-level, an independent analysis of the USDA would be an ideal step for continued research. Examining agricultural policy through the lens of the USDA would provide a better understanding of the influence the department may or may not 
have had on policy and the policy effects of interagency factions and politicking. In addition, taking a closer look at the presidency and the courts are also beneficial aspects to explore. While this analysis would further explore whether the actions of the president are linked to committee competition and efforts of issue redefinition, it would also explicitly assess whether decisions rendered by the court disrupt the turf monopoly maintained by the Agriculture Committees.

At the micro-level, focusing exclusively on how agricultural agencies comply or fail to comply with programs and implement policies is also an area for further discussion. For instance, comparing the Farm Security Administration to that of the Farmers Home Administration would further illustrate how organizational culture can influence program delivery (see Wilson, 1989). Moreover, such a comparison would also highlight the complexities of a principal-agent relationship that have been noted by various scholars (Golden, 2000; Brehm and Gates, 1999; Mitnick 1984). Another direction for exploration could originate at the state and local level. Evaluating how state agricultural policies diffuse across states and influence federal dialogue is also an interesting area to build upon. Likewise, studying the influence of state government on the development, structure, and makeup of county committees would provide a thorough understanding of the implications of agricultural policy emanating from the devolution of power. In conclusion, the congressional approach utilized for this research is only a beginning step in exploring the dynamic evolution of agricultural support policy and the travails of African American farmers. 


\section{References}

Adolino J.R, and Blake, C.H. (2001). Comparing Public Policies: Issues and Choices in Six Industrialized Countries. Washington, D.C. CQ Press.

Alston, L.J., Rucker,R.R, and Weidenmier, M.D. (2000). Did U.S. Agricultural Policy Lock Farmers into Wheat? The Capitalization of Farm Policies into Land Prices in the U.S. and Canada. Working paper from Claremont Institute of Economic Policy Studies.

Anderson, J. (1997). Public Policymaking. Boston: Houghton Mifflin Company.

Baum, L. (1997). The Puzzle of Judicial Behavior. Ann Arbor: The University of Michigan Press.

Baumgartner, F.R., and Jones, B.D. (2002). Positive and Negative Feedback in Politics. In Frank R. Baumgartner and Bryan D. Jones, ed., Policy Dynamics. Chicago: University Press.

Baumgartner, F.R., and Jones, B.D. (1993). Agendas and Instability in American Politics. Chicago: Chicago Press.

Baumgartner, F.R., and Jones, B.D. (1991). Agenda Dynamics and Policy Subsystems. The Journal of Politics. Vol 53, No.4. 1044-1074.

Berry, J. (1989). Subgovernments, Issue Networks, and Political Conflict. In Remaking American Politics, edited by Richard Harris, and Sidney, Milks, Boulder: Westview.

Bosso, C. J. (1987). Pesticides and politics: The life cycle of a public issue. Pittsburgh: University of Pittsburgh Press.

Box-Steffensmeier, J., Arnold L. and Christopher Zorn. (1997). The Strategic Timing Position-Taking in Congress: A Study of the North American Free Trade Agreement. American Political Science Review. Vol. 91: 324-338.

Brehm, J., and Gates, S. (1999). Working, Shirking, and Sabotage: Bureaucratic Response to a Democratic Public. Ann Arbor: The University of Michigan Press.

Brehm, J., and Rahn, W. (1997). Individual-level Evidence for the causes and consequences of Social Capital. American Journal of Political Science 41 (July,3): 999-1023. 
Brewer, A. G. (2003). When Core Values and Missions Collide: Gut Wrenching Change in the U.S. Department of Agriculture. Paper prepared at National Public Management Research Conference, Georgetown University, Washington, D.C., October 9-11.

Brooks, S. (1998). Public Policy in Canada: An Introduction. Ontario: Oxford University Press.

Brown, A. Jr. and Christy, R.D. (1994). Structural Changes in U.S. Agriculture: Implications for African American Farmers. Review of Black Political Economy 22 (Spring, 4): 51-72.

Browne, W.P. (1988). Private Interests Public Policy and American Agriculture. University Press of Kansas.

Browne, W.P. (2003). Benign Public Policies, Malignant Consequences, and the Demise of African American Agriculture. In Douglas Hurt, ed., African American Life in the Rural South, 1900-1950. Columbia Missouri: University of Missouri Press.

Burton, O.V. (1998). African American Status and Identity in a Postbellum Community: an Analysis of the Manuscript Census Returns, Agricultural History 72.

Calderia, W.A., and Wright, J.R. (1988). Organized Interests and Agenda Setting in the U.S. Supreme Court. The American Political Science Review, (December, 4): 1109-1127.

Callender, A, and Demelle, B. (2004). USDA Undermines Historic Civil Rights Settlement With Black Farmers. (EWG Report). Report is a joint project of the Environmental Working Group (EWG) and the National Black Farmers Association (NBFA); Project was made possible through a grant provided by Ford Foundation.

Carmines, E.G., and Stimson, J.A. (1989). Issue Evolution: Race and the Transformation of American Politics. Princeton, New Jersey. Princeton University Press.

Chanley, V., Thomas J, R., and Wendy, M, R. The Origin and Consequences of Public Trust in Government: A Time Series Analysis. Public Opinion Quarterly 64(3).

Chong, D. (1991). Collective Action and the Civil Rights Movement. Chicago, IL: The University of Chicago Press

Civil Rights Action Team. (1997). Civil Rights at the United States Department of Agriculture. Washington, D.C.: United States Department of Agriculture. 
Civil Rights Enforcement Record of the Department of Agriculture, $98^{\text {th }}$ Congress. September 26, 1984. Hearing before the House Subcommittee on Civil and Constitutional Rights.

Civil Rights Legislation, $105^{\text {th }}$ Congress. October 23, 1997. Hearing before the House Committee on Agriculture.

Cobb, J.C. (1992). The Most Southern Place on Earth. New York. Oxford University Press.

Cobb, R.W., and Elder, C.D. (1983). Participation in American politics: The dynamics of agenda setting. Baltimore, MD: John Hopkins University Press.

Cochrane, W.W., and Runge, F.C. (1992). Reforming Farm Policy: Toward a National Agenda. Ames: Iowa State University Press.

Conference Seeks To Empower Black Farmers, Landowners. (2002). Black Issues in Higher Education. Vol 19, Issues 6.

Cook, F.L. Et Al. (1983). Media and Agenda Setting: Effects on the public, interest group leaders, policy makers, and policy. Public Opinion Quarterly 47(Spring, 1): 1635.

Culver, J.C., and Hyde, J. (2000). American Dreamer: The Life and Times of Henry Wallace. New York: W.W. Norton.

Dearing, J.W., and Rogers, E.M. (1996). Communication Concepts 6, Agenda-Setting. Thousand Oaks, California: SAGE Publications, Inc.

Decline of Minority Farming in the U.S., $101^{\text {st }}$ Congress. July 25, 1990. Hearing before the House Subcommittee on Government Information, Justice, and Agriculture.

Downs, A. (1972). Up and down with ecology—The issue attention cycle. The Public Interest, 28, 38-50.

Du Bois, W.E.B. (1935). Black Reconstruction in America 1860-1880. New York: The Free Press.

Durant, R.F., and Diehl, P.F. (1989). Agendas, alternatives, and public policy: Lessons from the U.S. foreign policy arena. Journal of Public Policy, 9, 179-205).

Durr, R. (1993). What Moves Policy Sentiment? American Political Science Review, 87 (March, 1): 158-170.

Dye, T. (1985). Politics in States and Communities. Englewood Cliffs, New Jersey: Prentice-Hall, Inc. 
Elazar, D. (1966). The States and the Political Setting. In American Federalism: A View from the States. New York: Crowell, Chapter 5.

Eyestone, R. (1978). From Social Issues to Public Policy. New York: Wiley.

Environmental Working Group (EWG). (2004). Obstruction of Justice: USDA Undermines Historic Civil Rights Settlement with Black Farmers. July. Also available online: http://www.ewg.org/reports/blackfarmers/part2.php

Farm and Home Foreclosures, $98^{\text {th }}$ Congress. March 14, 1983. Hearing before the Senate Subcommittee on Courts.

Fears, D. (2004). Victory Slipping Away for Black Farmers. Washington Post. July 20, page A15.

Fiorina, M.P. (1989). Congress: Keystone of the Washington Establishment. 2d. Yale University Press: New Haven.

Fisher, J.S. (December 1973). Negro Farm Ownership in the South. Annuals of the Association of American Geographers 63, no.4: 478-489.

Fite, G.C. (1984). Cotton Fields No More. Lexington: University Press of Kentucky.

Flemming, R.B., Bohte J., and Wood, D.B. (1997). One Voice Among Many: The Supreme Court's Influence on Attentiveness to Issues in the United States. American Journal of Political Science 41(October, 4): 1224-1250.

Franklin, J.H. (1947). From Slavery to Freedom. Alfred A. Knopf, Inc. Freeman, L.J. (1965). The Political Process: Executive Bureau-Legislative Committee Relations. New York: Random House.

Gandy, O. H Jr. (1982). Beyond Agenda Setting: Information Subsidies and Public Policy. Norwood, New Jersey: Ablex Publishing Company

Gardner, B. (2002) Agricultural Policy: Pre-and Post-FAIR Act Comparisons. Eds, Luther Tweeten and Stanley R. Thompson (2002). Agricultural Policy for the $21^{\text {st }}$ Century.

Gilbert, C., Eli Q. (2000). Homecoming, The Story of African-American Farmers. Boston Massachusetts: Boston Press.

Golden, M.M. (2000) What Motivates Bureaucrats? Politics and Administration During the Reagan Years. New York: Columbia University Press.

Grant, G. (2004). Black Farmer’s Prayer Vigil and Sit-In. Progressive Magazine. July. 
Gray et Al. (2002). The Opinion-Policy Linkage in the American States: Professional Legislatures, Organized Interest, and Policy Responsiveness. Paper Presented at the second annual state politics and policy conference, University Wisconsin at Milwaukee.

Grossback, L. (2000). Public Policy, Public Opinion, and the Process of Democratic Responsivness. Chapters 1,2,3, and 5.

Hansen, M.J. (1991). Gaining Access: Congress and the Farm Lobby, 1919-1981. Chicago: University of Chicago Press.

Hasan, N.S., and Simmons, J.R. (1989). The Issue Attention Cycle: More Ups than Downs Anticipated. Paper presented at Midwest Political Science Association, Chicago.

Hawley, E.W. (1989). The New Deal State and the Anti-Bureaucratic Tradition. Eds Robert Eden, (19890). The New Deal and Its Legacy. New York: Greenwood Press.

Hofrenning, D.J. (1989). The Agenda-Setting Strategies of Religious Interest Groups and Institutions. Paper presented at American Political Science Association, Atlanta.

Howard, R. and Donnelly J. (1986). Human Dignity, Human Rights, and Political Regimes. The American Political Science Review Vol(80): 801-817.

Huffman, W.E. (1981). Black-White Human Capital Differences: Impact on Agricultural Productivity in the U.S. South. The American Economic Review, Vol.71, 94-107.

Hardin, J.W. (2002). Multiple Topics, Multiple Targets, Multiple Goals, and Multiple Decision Makers: Congressional Consideration of Comprehensive Health Care Reform. In Frank R. Baumgartner and Bryan D. Jones, ed., Policy Dynamics. Chicago: University Press.

Higgs, R. (1977). Competition and Coercion: Blacks in the American Economy 18651914. Chicao, IL: University of Chicago Press.

Hunt, V. (2002). The Multiple and Changing Goals of Immigration Reform: A Comparison of House and Senate Activity, 1947-1993. In Frank R. Baumgartner and Bryan D. Jones, ed., Policy Dynamics. Chicago: University Press.

Ingersoll, B. (2000). Iowa Farm Aid Helped Rich Most, Study Says. Wall Street Journal. January, 14.

Iyengar, S., and Donald, R.K. (1987). News that Matters. Chicago: The University of Chicago Press. Chapters 1-3, 12. 
Jones, C. and Strahan R. (1985). The Effect of Energy Politics on Congressional and Executive Organization in the 1970s. Legislative Studies Quarterly 10: 151-79.

Jones, B.D., Baumgartner, F.R., and Erin de la Mare. (2005). The Supply of Information and the Size of Government in the United States. April. Forthcoming.

Jones, C. (1984). An Introduction to the Study of Public Policy. 3d ed. Monterey, California: Brooks/Cole.

Kellstedt, P.M. (2000). Media Framing and the Dynamics of Racial Policy Preferences. American Journal of Political Science 44(April, 2): 245-260.

Kennedy, J.V., and Vissere J. (1990). An Introduction to U.S. Agricultural Programs. Eds, Kristen Allen (1990). Agricultural Policies in a New Decade. Washington D.C. Resources for the Future.

Kernell, S. (1993). Going Public: New Strategies of Presidential Leadership. Congressional Quarterly, Inc.

Key, V.O. Jr. (1964). Politics, Parties, and Pressure Groups. New York: Thomas Y. Crowell Company.

King, D. C. (1997). Turf Wars. Chicago: The University of Chicago Press

Kingdon, J.W. (1995). Agendas, Alternatives, and Public Policies. NewYork: Addison Wesley Longman.

Klinkner, P.A. and Smith, R. (1999). The Unsteady March: The Rise and Decline of Racial Equality in America. Chicago and London: University of Chicago Press.

Less, J. D. (1967). Committee System of the United States Congress. New York: Humanities Press.

Leyden, K. (1995). Interest Group Resources and Testimony at Congressional Hearings. Legislative Studies Quarterly. Vol.20, No.3. 431-439.

Lillston, B., and Neil, R. (2000). Freedom to Fail. Multinational Monitor; Aug.

Light, P. (1999). The President's Agenda $3^{\text {rd }}$ Ed. Baltimore, MD: The Johns Hopkins University Press.

Lindsay, J.M. (2002). The Promise and Peril of Legislative Reform. In Thomas E. Mann and Sasaki Takeshi, ed., From Governance for a new century: Japanese Challenges, American Experience. Tokyo: Japan Center for International Exchange. 
Lockhart, C. (1984). Explaining Social Policy Differences Among Advanced Industrial Societies. Comparative Politics 16, 342-348.

Lowi, T. (1969). American Business, Public Policy, Case Studies, and Political Theory. World Politics 15. 677-715.

Magdol, E. (1977). A Right to the Land: Essays on Freedmen's Community. Westport, Connecticut: Greenwood Press.

Marshall, R. and Godwin, L. (1971). Cooperative and Rural Poverty in the South. Baltimore, MD: John Hopkins Press.

Mayew, D. (1974). Congress: The electoral connection. New Haven: Yale University Press.

McCool, D. (1998). The Subsystem Family of Concepts: A Critique and a Proposal. Political Research Quarterly, Vol. 51, No.2. 551-570.

McDowell, G.R. (2001). Land-Grant Universities and Extension into the $21^{\text {st }}$ Century: Renegotiating or Abandoning a Social Contract. Ames, Iowa: Iowa State University Press.

MCGraw, M., and Jeff T. (1991). Driven off the Land. Kansas City Star, December 11.

McGuire, K., and Palmer, B. (1996). Issues, Agendas, and Decision Making on the Supreme Court. American Political Science Review 90: 853-865.

McLean-Meyinsse, P.E., and Brown, A. Jr. (1994). Survival strategies of successful black farmers. Review of Black Political Economy. 73-84.

Milakovich, M. E., and Gordon, J.G. (2001). Public Administration in America. Boston: Bedford/St. Martin’s.

Mitnick, B. (1984). The bureaucrat as agent. Paper presented at APSA Meeting, Washington, D.C.

Mittal, A and Powell, J. (2000). The Last Plantation. Institute for Food and Development Policy Backgrounder. Vol.6, No. 1. Winter. 1-9.

Muhammad, R.A.M. (2002). A Farmer's Fight is Never Over. The Farmer. Vol 5, No.24. July.

Nelson, B.J. (1984). Making an issue of Child Abuse. Chicago: University of Chicago Press. 
Neustadt, R. E. (1990). Presidential Power and the Modern Presidents: The Politics of Leadership From Roosevelt To Reagan. New York: The Free Press.

Paarlberg, D. (1989). Tarnished Gold: Fifty Years of New Deal Farm Programs. In Robert Eden, ed., The New Deal and Its Legacy, Critique and Reappraisal. New York: Greenwood Press.

Peterson, P. (1995). The Price of Federalism. Washington, D.C.: The Brookings Institution.

Perry, H.W. (1991). Deciding to Decide: Agenda Setting in the United States Supreme Court. Cambridge, MA: Harvard University Press.

Peters, B.G. (1998). Comparative Politics: Theory and Methods. New York: New York University Press.

Pigford 1999. Pigford V. Glickman, 185 F.R.D. 82 (D.D.C. 1999)

Plein, C. (1991). Popularizing Biotechnology: The Influence of Issue Definition. Science, Technology, \& Human Values, Vol.16 No.4, 474-490.

Pont, du. P. (1996). Medley From the Popcorn Follies. Washington Times. April 30.

Quadagno, J. (1988). The Transformation of Old Age Security. Chicago: University of Chicago Press.

Ransom, R. and Richard S. (1977). One Kind of Freedom: The Economic Consequences of Emancipation. New York: Cambridge University Press.

Rasmussen, W.B. and Baker, B.L. (1972). The Department of Agriculture. New York: Prager.

Reid, D. A. (2003) African Americans and Land Loss in Texas: Government Duplicity and Discrimination Based on Race and Class. Agricultural History, Vol. No. 77, 258-293.

Reynolds, B.J. (2002). Black Farmers in America, 1865-2000: The Pursuit of Independent Farming and the Role of Cooperatives. Rural Business-Cooperative Service Report 194. United States Department of Agriculture. 1-24.

Ripley, R. (1985). Policy Analysis in Political Science. Chicago: Nelson Hall Inc.

Rosenberg, G.N. (1991). The Hollow Hope. Chicago and London: The University of Chicago. 
Rosenthal, A. (1998). The Decline of Representative Democracy. Washington, D.C.: Congressional Quarterly Inc.

Rubinstein, A., and Dookhun, V. (1998). Black Farmers Hold Conference in Alabama. The Militant. Vol 62. No.32.

Sabatier, P.A., and Smith, H.J. (1993). Policy Change and Learning: An Advocacy Coalition Approach. Boulder, CO: Westview Press.

Sabatier, P. A. and Smith, H.J. (1999). The Advocacy Coalition Framework: An Assessment. In P.A. Sabatier (ed), Theories of the Policy Process. Boulder, CO: Westview. pp. 117-166.

Schiller, W. (1995). Senators as Political Entrepreneurs: Using Bill Sponsorship to Shape Legislative Agendas. American Journal of Political Science. Vol. 39, No.1: February, 186-203.

Scholzman, K., and Tierney, J. (1986). Organized Interests and American Democracy. New York: Harper and Rowe.

Schultze, C.L. (1971). The Distribution of Farm Subsidies: Who Gets the Benefits? Washington, DC: Brookings Institution.

Sheingate, A.D. (2001). The rise of the agricultural welfare state: institutions and interest group power in the United States, France, and Japan. Princeton.

Sherrod, S. Political Engagement in Neighborhoods: Stories and Strategies. National Neighborhood Coalition Community Engagement Forum, July 29, 2004.

Simon, H.A. (1983). Reason in Human Affairs. Stanford, California: Stanford University Press.

Sinclair, B. (1989). The Transformation of the U.S. Senate. Baltimore: John Hopkins Press.

Skowronek, S. (1982). Building a New American State: The Expansion of National Administrative Capacities, 1877-1920. Cambridge University Press.

Smith, H. and Hoff, K. (1997). USDA Civil Rights Action Team Releases Report. Farm Aid News and Views. February, Vol 5. No. 3. 1-7.

Smith, K. (1998). Black Farmers Have Beef With The USDA. Black Enterprise. Vol.28, Issue 6. 
Smith, R.M. (1997). Civic Ideals, Conflicting Visions of Citizenship in U.S. History. Michigan: Yale University Press.

Spitze, R.G.F, S. Walter Deray and J. West. (1980). Public Agricultural-Food Policies and Small Farms. Produced as Paper I of the National Rural Center Small Farms Project (Washington, D.C.: The National Rural Center).

Stimson, J.A., Michael B. M., and Robert, S.E. (1995). Dynamic Representation. American Political Science Review 89 (September, 3): 543-565.

Stimson, J.A. (1999). Public Opinion in America: Moods, Cycles, and Swings. $2^{\text {nd }}$ Ed. Boulder, Westview Press.

Studlar, D. T. (1990). Nonwhite Minority Access to the Political Agenda in Britian. Policy Studies Review, (Winter, 2): 273-293.

Talbert, J. C., Bryan D. Jones and Frank R. Baumgartner. (1995). Nonlegislative Hearings and Policy Change in Congress. American Journal of Political Science 39(2, May): 383-405.

Traugott, M.W. (1992). The Impact of Media Polls on the Public. In Thomas E. Mann and Gary Orren, eds., Media Polls in American Politics. Washington, DC: Brookings.

Treatment of Minority and Limited Resource Producers by the U.S. Department of Agriculture, $105^{\text {th }}$ Congress. March 19, July 17, 1997. Hearing before the Hosue Subcommittee on Department Operations, Nutrition, and Foreign Agriculture.

Tweeten, L. (1985). Farm Financial Stress, Structure of Agriculture, and Public Policy. In Bruce Gardner, eds., U.S. Agriculture Policy: The 1985 Farm Legislation. Washington, D.C.

Tzoumis, K. (2001). Environmental Policymaking in Congress: The Role of Issue Definitions in Wetlands, Greatlakes and Wildlife Policies. New York: Routledge.

U.S. Commission on Civil Rights. (1965). Equal Opportunity in Farm Programs: An Appraisal of Services Rendered by Agencies of the United States Department of Agriculture. Washington, D.C.: U.S. GPO.

U.S. Commission on Civil Rights. (1982) The Decline of Black Farming in America: A Report of the United States Commission on Civil Rights. Washington, D.C.: U.S. GPO.

Vogeler, I. (1981). The Myth of the Family Farm: Agribusiness Dominance of U.S. Agriculture. West view Press. Boulder, Colorado. 
Walker, J.L. (1977). Setting the agenda in the U.S. Senate: A theory of problem selection. British Journal of Political Science, 7, 423-445.

Wawro, G. (2001). Legislative Entrepreneurship in the U.S. House of Representatives. The University of Michigan Press. Ann Arbor.

Whately, W.C. (1983). Labor for the Picking: The New Deal in the South. The Journal of Economic History, Vol.43, no.4 905-929.

Wilkerson, J.D., Feeley, T.J., Schiereck, N.S., and Sue, C. (1999). Policy Interest and Legislative Responsiveness: Bill Introductions as Indicators of Issue Salience. Paper presented at the 1999 Annual Meetings of the American Political Science Association in Atlanta Georgia.

Wilson, J. Q. (1989). Bureaucracy. Basic Books, Inc.

Wood, S.D. and Gilbert, J. (2000). Returning African American Farmers to the Land: Recent Trends and a Policy Rationale. Black Political Economy, Spring.

Wood, B. D. and Jeffrey S.P. (1998). The Dynamics of Foreign Policy Agenda Setting. American Political Science Review, 92: 173-184.

Worsham, J., Stores, C., and Kapla, D. (2004). A long row to hoe: Setting the agenda for African American farmers, 1935-2002. Paper presented at the 2004 Annual Meeting of the American Political Science Association, Chicago, September, 2004. Copyright by the American Political Science Association.

Worsham, J., and Stores, C. (2004). 40 acres and a mule: The Congressional treatment of African American farmers, 1945-1996. Paper presented at the 2004 Annual Midwest Science Association, Chicago, April, 2004. Copyright by the Midwest Political Science Association.

Worsham, J. (1998). Wavering Equilibriums: Subsystem Dynamics and Agenda Control. American Politics Quarterly 26(October, 4): 485-512.

Zelizer, J.E. (2004). On Capitol Hill, The Struggle to Reform Congress and Its Consequences, 1948-2000. Cambridge University Press.

Zinn, H. (1997). People’s History of the United States. New York: New Press.

http://www.federationsoutherncoop.com

www.blackfarmers.org/main.htm

http://bfaa-us.org 
*Benefits and explanations of summary table 2.1 see:

Browne, W.P. (1988). Private Interests, Public Policy and American Agriculture. University Press of Kansas.

Hurt, R.D. (1994). American Agriculture: A Brief History. Ames: Iowa State University Press.

Hansen, M.J. (1991). Gaining Access: Congress and the Farm Lobby, 1919-1981. Chicago: University of Chicago Press. 


\section{APPENDIX A: $\quad$ House Agriculture Topic Matrix}

On the following pages, a matrix is used to illustrate the distribution of bill introductions in the House by topic for the selected analysis period. Although not shown, the topic matrix for the Senate is structured in the same format.

\begin{tabular}{|c|c|c|c|c|c|c|c|c|c|c|}
\hline Year & Labor & $\begin{array}{l}\text { Soil } \\
\text { Conservation }\end{array}$ & \begin{tabular}{|l|} 
Family \\
Farms
\end{tabular} & Insurance & \begin{tabular}{|l|} 
Disaster \\
Assitance
\end{tabular} & Cotton & Income & $\begin{array}{l}\text { County } \\
\text { Comm. }\end{array}$ & \begin{tabular}{|l|} 
Price \\
Supports
\end{tabular} & $\begin{array}{l}\text { Farm } \\
\text { Loans }\end{array}$ \\
\hline 1939 & & & & & & & & & & 2 \\
\hline 1940 & 1 & & 1 & 2 & 1 & 2 & 1 & 1 & 22 & 3 \\
\hline 1941 & 4 & 1 & 4 & & 7 & 13 & & 2 & 40 & 5 \\
\hline 1942 & & & 1 & & 1 & 4 & 1 & & 11 & 3 \\
\hline 1943 & 5 & & 1 & & & & 1 & 2 & 22 & 1 \\
\hline 1944 & & & & & 2 & 4 & & & 5 & \\
\hline 1945 & 1 & & & & & 3 & & & & \\
\hline 1946 & & & & & & & & & & \\
\hline 1947 & & & & & & & & & & 1 \\
\hline 1948 & 1 & 1 & & & & 2 & & & & \\
\hline 1949 & 2 & 3 & & 2 & & 4 & & & 1 & 1 \\
\hline 1950 & & & & & & & & & & 1 \\
\hline 1951 & & & & & & 1 & & & 1 & \\
\hline 1952 & & 3 & & & & 1 & & & & \\
\hline 1953 & 1 & & & & & 8 & & & 2 & 8 \\
\hline 1954 & 1 & & & & & 1 & & & & 4 \\
\hline 1955 & 4 & & 3 & & & 1 & & & 12 & 12 \\
\hline 1956 & 1 & & 1 & & & 2 & & & 7 & 18 \\
\hline 1957 & 10 & 14 & 12 & 3 & & 58 & 9 & & 58 & 2 \\
\hline 1958 & & 4 & 1 & & & 49 & 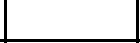 & & 13 & 8 \\
\hline 1959 & 6 & 1 & 5 & & & 12 & 4 & & 23 & \\
\hline 1960 & & 5 & 42 & & & 10 & & 11 & 22 & 3 \\
\hline 1961 & & 1 & & 1 & 1 & 12 & 3 & 4 & 6 & 5 \\
\hline 1962 & & 11 & & & & 7 & 3 & & 5 & 3 \\
\hline 1963 & & 33 & 1 & & & 24 & & 3 & 1 & 2 \\
\hline 1964 & & 1 & & & & & & & 1 & 2 \\
\hline 1965 & & 25 & & & 1 & 50 & 1 & 3 & & 5 \\
\hline 1966 & & 8 & & & 1 & 2 & & & 6 & 5 \\
\hline 1967 & & 10 & & & & 12 & & 4 & 7 & 9 \\
\hline 1968 & & 1 & & & & 2 & & 1 & & 16 \\
\hline 1969 & & 4 & 1 & 3 & & 1 & 1 & & 1 & 52 \\
\hline 1970 & & 14 & & & & 2 & & & & 10 \\
\hline 1971 & & 2 & 4 & 2 & & 2 & & 2 & & 49 \\
\hline 1972 & 2 & & 2 & & & 2 & & 1 & 1 & 2 \\
\hline 1973 & & & 4 & & & & & 1 & 4 & 32 \\
\hline 1974 & & & & & & 2 & & & 3 & 15 \\
\hline 1975 & & 3 & 22 & 1 & & 6 & & 1 & 6 & 28 \\
\hline 1976 & & & 8 & & & & & 4 & & 6 \\
\hline 1977 & & 1 & 14 & 7 & 18 & 2 & & 11 & & 40 \\
\hline 1978 & & & 10 & 1 & 1 & 23 & & 1 & 1 & 11 \\
\hline 1979 & & 2 & 7 & 2 & 4 & 15 & & 5 & & 23 \\
\hline 1980 & & & 3 & & & 1 & & & & 35 \\
\hline 1981 & & 4 & 2 & 1 & & 6 & & 1 & 1 & 25 \\
\hline 1982 & & 4 & & 1 & $t$ & & 2 & 1 & 1 & 23 \\
\hline
\end{tabular}




\begin{tabular}{|c|c|c|c|c|c|c|c|c|c|}
\hline 1983 & 11 & & 3 & & 5 & 1 & 1 & 12 & 20 \\
\hline 1984 & & & 1 & & & & & & 6 \\
\hline 1985 & 8 & 1 & 1 & & & & 1 & 12 & 43 \\
\hline 1986 & 1 & 1 & 1 & & 2 & ?t & 1 & 4 & 31 \\
\hline 1987 & 7 & & 1 & 3 & & 4 & 1 & 2 & 40 \\
\hline 1988 & 4 & & 2 & & & & & 1 & 4 \\
\hline 1989 & 1 & & 1 & 7 & & & 1 & 2 & 5 \\
\hline 1990 & 3 & & 5 & 7 & 2 & 1 & 2 & 3 & 4 \\
\hline \begin{tabular}{|l|}
1991 \\
\end{tabular} & 1 & 1 & & 4 & & & 1 & & 10 \\
\hline \begin{tabular}{|l|}
1992 \\
\end{tabular} & 1 & & 1 & 2 & 2 & 2 & 2 & 2 & 6 \\
\hline 1993 & & & 1 & 2 & & & 2 & 1 & 5 \\
\hline \begin{tabular}{|l|}
1994 \\
\end{tabular} & 1 & & 1 & & & & & 1 & 4 \\
\hline 1995 & 2 & & 1 & 1 & 2 & 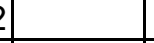 & 1 & 2 & 3 \\
\hline 1996 & 1 & & 1 & & & & & 2 & 1 \\
\hline \begin{tabular}{|l|}
1997 \\
\end{tabular} & 1 & 1 & 2 & & & & & 1 & 1 \\
\hline 1998 & 1 & 1 & & 3 & & & 1 & & 2 \\
\hline
\end{tabular}




\section{APPENDIX B: $\quad$ House Committee Competition Matrix}

On the following pages, a matrix is used to illustrate the distribution of congressional agricultural hearings held in the House by each committee for the selected analysis period. Although not shown, the committee competition matrix for the Senate is structured in the same format.

\begin{tabular}{|c|c|c|c|c|c|c|c|c|c|c|c|c|c|c|c|c|c|c|c|}
\hline year & Agriculture & Banking & Interior & \begin{tabular}{|l|} 
Ways \\
$\&$ \\
Means
\end{tabular} & \begin{tabular}{|l|} 
Small \\
Business
\end{tabular} & \begin{tabular}{|l|} 
Post \\
Office \\
\&Civil \\
Service \\
\end{tabular} & Inter.Rel & $\begin{array}{l}\text { Merchant } \\
\text { Marine }\end{array}$ & \begin{tabular}{|l|} 
Foreign \\
Affiars
\end{tabular} & $\begin{array}{l}\text { Interstate } \\
\text { \& Foreign } \\
\text { Commerce }\end{array}$ & $\begin{array}{l}\text { Science } \\
\text { \& Tech. }\end{array}$ & Economic & Energy & \begin{tabular}{|l|} 
Govt. \\
Reform
\end{tabular} & Flood & Judiciary & \begin{tabular}{|l|} 
Public \\
Works
\end{tabular} & \begin{tabular}{|l|} 
Govt. \\
Operations
\end{tabular} & \begin{tabular}{|l|} 
Education \\
\& Labor
\end{tabular} \\
\hline 1939 & $50 \%$ & $50 \%$ & $0 \%$ & $0 \%$ & $0 \%$ & $0 \%$ & $0 \%$ & $0 \%$ & $0 \%$ & $0 \%$ & $0 \%$ & $0 \%$ & $0 \%$ & $0 \%$ & $0 \%$ & $0 \%$ & $0 \%$ & $0 \%$ & $0 \%$ \\
\hline 1940 & $50 \%$ & $25 \%$ & $0 \%$ & $0 \%$ & $0 \%$ & $0 \%$ & $0 \%$ & $0 \%$ & $0 \%$ & $0 \%$ & $0 \%$ & $0 \%$ & $0 \%$ & $0 \%$ & $0 \%$ & $13 \%$ & $13 \%$ & $0 \%$ & $0 \%$ \\
\hline \begin{tabular}{|l|}
1941 \\
\end{tabular} & $33 \%$ & $67 \%$ & $0 \%$ & $0 \%$ & $0 \%$ & $0 \%$ & $0 \%$ & $0 \%$ & $0 \%$ & $0 \%$ & $0 \%$ & $0 \%$ & $0 \%$ & $0 \%$ & $0 \%$ & $0 \%$ & $0 \%$ & $0 \%$ & $0 \%$ \\
\hline 1942 & $0 \%$ & $0 \%$ & $0 \%$ & $0 \%$ & $0 \%$ & $0 \%$ & $0 \%$ & $0 \%$ & $0 \%$ & $0 \%$ & $0 \%$ & $0 \%$ & $0 \%$ & $0 \%$ & $0 \%$ & $0 \%$ & $0 \%$ & $0 \%$ & $0 \%$ \\
\hline \begin{tabular}{|l|}
1943 \\
\end{tabular} & $50 \%$ & $50 \%$ & $0 \%$ & $0 \%$ & $0 \%$ & $0 \%$ & $0 \%$ & $0 \%$ & $0 \%$ & $0 \%$ & $0 \%$ & $0 \%$ & $0 \%$ & $0 \%$ & $0 \%$ & $0 \%$ & $0 \%$ & $0 \%$ & $0 \%$ \\
\hline 1944 & $100 \%$ & $0 \%$ & $0 \%$ & $0 \%$ & $0 \%$ & $0 \%$ & $0 \%$ & $0 \%$ & $0 \%$ & $0 \%$ & $0 \%$ & $0 \%$ & $0 \%$ & $0 \%$ & $0 \%$ & $0 \%$ & $0 \%$ & $0 \%$ & $0 \%$ \\
\hline \begin{tabular}{|l|}
1945 \\
\end{tabular} & $50 \%$ & $25 \%$ & $0 \%$ & $0 \%$ & $0 \%$ & $0 \%$ & $0 \%$ & $0 \%$ & $0 \%$ & $0 \%$ & $0 \%$ & $0 \%$ & $0 \%$ & $0 \%$ & $25 \%$ & $0 \%$ & $0 \%$ & $0 \%$ & $0 \%$ \\
\hline 1946 & $100 \%$ & $0 \%$ & $0 \%$ & $0 \%$ & $0 \%$ & $0 \%$ & $0 \%$ & $0 \%$ & $0 \%$ & $0 \%$ & $0 \%$ & $0 \%$ & $0 \%$ & $0 \%$ & $0 \%$ & $0 \%$ & $0 \%$ & $0 \%$ & $0 \%$ \\
\hline \begin{tabular}{|l|}
1947 \\
\end{tabular} & $100 \%$ & $0 \%$ & $0 \%$ & $0 \%$ & $0 \%$ & $0 \%$ & $0 \%$ & $0 \%$ & $0 \%$ & $0 \%$ & $0 \%$ & $0 \%$ & $0 \%$ & $0 \%$ & $0 \%$ & $0 \%$ & $0 \%$ & $0 \%$ & $0 \%$ \\
\hline \begin{tabular}{|l|}
1948 \\
\end{tabular} & $100 \%$ & $0 \%$ & $0 \%$ & $0 \%$ & $0 \%$ & $0 \%$ & $0 \%$ & $0 \%$ & $0 \%$ & $0 \%$ & $0 \%$ & $0 \%$ & $0 \%$ & $0 \%$ & $0 \%$ & $0 \%$ & $0 \%$ & $0 \%$ & $0 \%$ \\
\hline \begin{tabular}{|l|}
1949 \\
\end{tabular} & $100 \%$ & $0 \%$ & $0 \%$ & $0 \%$ & $0 \%$ & $0 \%$ & $0 \%$ & $0 \%$ & $0 \%$ & $0 \%$ & $0 \%$ & $0 \%$ & $0 \%$ & $0 \%$ & $0 \%$ & $0 \%$ & $0 \%$ & $0 \%$ & $0 \%$ \\
\hline \begin{tabular}{|l|}
1950 \\
\end{tabular} & $67 \%$ & $33 \%$ & $0 \%$ & $0 \%$ & $0 \%$ & $0 \%$ & $0 \%$ & $0 \%$ & $0 \%$ & $0 \%$ & $0 \%$ & $0 \%$ & $0 \%$ & $0 \%$ & $0 \%$ & $0 \%$ & $0 \%$ & $0 \%$ & $0 \%$ \\
\hline \begin{tabular}{|l|}
1951 \\
\end{tabular} & $100 \%$ & $0 \%$ & $0 \%$ & $0 \%$ & $0 \%$ & $0 \%$ & $0 \%$ & $0 \%$ & $0 \%$ & $0 \%$ & $0 \%$ & $0 \%$ & $0 \%$ & $0 \%$ & $0 \%$ & $0 \%$ & $0 \%$ & $0 \%$ & $0 \%$ \\
\hline \begin{tabular}{|l|}
1952 \\
\end{tabular} & $0 \%$ & $0 \%$ & $0 \%$ & $0 \%$ & $0 \%$ & $0 \%$ & $0 \%$ & $0 \%$ & $0 \%$ & $0 \%$ & $0 \%$ & $0 \%$ & $0 \%$ & $0 \%$ & $0 \%$ & $0 \%$ & $0 \%$ & $0 \%$ & $0 \%$ \\
\hline 1953 & $57 \%$ & $14 \%$ & $0 \%$ & $0 \%$ & $0 \%$ & $0 \%$ & $0 \%$ & $0 \%$ & $0 \%$ & $0 \%$ & $0 \%$ & $0 \%$ & $0 \%$ & $0 \%$ & $0 \%$ & $0 \%$ & $0 \%$ & $29 \%$ & $0 \%$ \\
\hline \begin{tabular}{|l|}
1954 \\
\end{tabular} & $100 \%$ & $0 \%$ & $0 \%$ & $0 \%$ & $0 \%$ & $0 \%$ & $0 \%$ & $0 \%$ & $0 \%$ & $0 \%$ & $0 \%$ & $0 \%$ & $0 \%$ & $0 \%$ & $0 \%$ & $0 \%$ & $0 \%$ & $0 \%$ & $0 \%$ \\
\hline \begin{tabular}{|l|}
1955 \\
\end{tabular} & $60 \%$ & $20 \%$ & $0 \%$ & 0\% & $0 \%$ & $0 \%$ & $0 \%$ & $0 \%$ & $0 \%$ & $0 \%$ & $0 \%$ & $0 \%$ & $0 \%$ & $0 \%$ & $0 \%$ & $0 \%$ & $0 \%$ & $20 \%$ & $0 \%$ \\
\hline \begin{tabular}{|l|}
1956 \\
\end{tabular} & 91\% & $9 \%$ & $0 \%$ & $0 \%$ & $0 \%$ & $0 \%$ & $0 \%$ & $0 \%$ & $0 \%$ & $0 \%$ & $0 \%$ & $0 \%$ & $0 \%$ & $0 \%$ & $0 \%$ & $0 \%$ & $0 \%$ & $0 \%$ & $0 \%$ \\
\hline \begin{tabular}{|l|}
1957 \\
\end{tabular} & $100 \%$ & $0 \%$ & $0 \%$ & $0 \%$ & $0 \%$ & $0 \%$ & $0 \%$ & $0 \%$ & $0 \%$ & $0 \%$ & $0 \%$ & $0 \%$ & $0 \%$ & $0 \%$ & $0 \%$ & $0 \%$ & $0 \%$ & $0 \%$ & $0 \%$ \\
\hline \begin{tabular}{|l|}
1958 \\
\end{tabular} & $100 \%$ & $0 \%$ & $0 \%$ & $0 \%$ & $0 \%$ & $0 \%$ & $0 \%$ & $0 \%$ & $0 \%$ & $0 \%$ & $0 \%$ & $0 \%$ & $0 \%$ & $0 \%$ & $0 \%$ & $0 \%$ & $0 \%$ & $0 \%$ & $0 \%$ \\
\hline \begin{tabular}{|l|}
1959 \\
\end{tabular} & $100 \%$ & $0 \%$ & $0 \%$ & $0 \%$ & $0 \%$ & $0 \%$ & $0 \%$ & $0 \%$ & $0 \%$ & $0 \%$ & $0 \%$ & $0 \%$ & $0 \%$ & $0 \%$ & $0 \%$ & $0 \%$ & $0 \%$ & $0 \%$ & $0 \%$ \\
\hline 1960 & $100 \%$ & $0 \%$ & $0 \%$ & $0 \%$ & $0 \%$ & $0 \%$ & $0 \%$ & $0 \%$ & $0 \%$ & $0 \%$ & $0 \%$ & $0 \%$ & $0 \%$ & $0 \%$ & $0 \%$ & $0 \%$ & $0 \%$ & $0 \%$ & $0 \%$ \\
\hline \begin{tabular}{|l|}
1961 \\
\end{tabular} & $100 \%$ & $0 \%$ & $0 \%$ & $0 \%$ & $0 \%$ & $0 \%$ & $0 \%$ & $0 \%$ & $0 \%$ & $0 \%$ & $0 \%$ & $0 \%$ & $0 \%$ & $0 \%$ & $0 \%$ & $0 \%$ & $0 \%$ & $0 \%$ & $0 \%$ \\
\hline \begin{tabular}{|l|}
1962 \\
\end{tabular} & $100 \%$ & $0 \%$ & $0 \%$ & $0 \%$ & $0 \%$ & $0 \%$ & $0 \%$ & $0 \%$ & $0 \%$ & $0 \%$ & $0 \%$ & $0 \%$ & $0 \%$ & $0 \%$ & $0 \%$ & $0 \%$ & $0 \%$ & $0 \%$ & $0 \%$ \\
\hline \begin{tabular}{|l|}
1963 \\
\end{tabular} & $0 \%$ & $0 \%$ & $0 \%$ & $0 \%$ & $0 \%$ & $0 \%$ & $0 \%$ & $0 \%$ & $0 \%$ & $0 \%$ & $0 \%$ & $0 \%$ & $0 \%$ & $0 \%$ & $0 \%$ & $0 \%$ & $0 \%$ & $0 \%$ & $0 \%$ \\
\hline 1964 & $100 \%$ & $0 \%$ & $0 \%$ & $0 \%$ & $0 \%$ & $0 \%$ & $0 \%$ & $0 \%$ & $0 \%$ & $0 \%$ & $0 \%$ & $0 \%$ & $0 \%$ & $0 \%$ & $0 \%$ & $0 \%$ & $0 \%$ & $0 \%$ & $0 \%$ \\
\hline
\end{tabular}




\begin{tabular}{|c|c|c|c|c|c|c|c|c|c|c|c|c|c|c|c|c|c|c|c|}
\hline 1965 & $67 \%$ & $0 \%$ & $0 \%$ & $0 \%$ & $0 \%$ & $0 \%$ & $0 \%$ & $0 \%$ & $0 \%$ & $0 \%$ & $0 \%$ & $0 \%$ & $0 \%$ & $0 \%$ & $0 \%$ & $0 \%$ & $0 \%$ & $0 \%$ & $33 \%$ \\
\hline \begin{tabular}{|l|}
1966 \\
\end{tabular} & $100 \%$ & $0 \%$ & $0 \%$ & $0 \%$ & $0 \%$ & $0 \%$ & $0 \%$ & $0 \%$ & $0 \%$ & $0 \%$ & $0 \%$ & $0 \%$ & $0 \%$ & $0 \%$ & $0 \%$ & $0 \%$ & $0 \%$ & $0 \%$ & $0 \%$ \\
\hline \begin{tabular}{|l|}
1967 \\
\end{tabular} & $100 \%$ & $0 \%$ & $0 \%$ & $0 \%$ & $0 \%$ & $0 \%$ & $0 \%$ & $0 \%$ & $0 \%$ & $0 \%$ & $0 \%$ & $0 \%$ & $0 \%$ & $0 \%$ & $0 \%$ & $0 \%$ & $0 \%$ & $0 \%$ & $0 \%$ \\
\hline \begin{tabular}{|l|}
1968 \\
\end{tabular} & $100 \%$ & $0 \%$ & $0 \%$ & $0 \%$ & $0 \%$ & $0 \%$ & $0 \%$ & $0 \%$ & $0 \%$ & $0 \%$ & $0 \%$ & $0 \%$ & $0 \%$ & $0 \%$ & $0 \%$ & $0 \%$ & $0 \%$ & $0 \%$ & $0 \%$ \\
\hline \begin{tabular}{|l|}
1969 \\
\end{tabular} & $50 \%$ & $0 \%$ & $0 \%$ & $0 \%$ & $0 \%$ & $0 \%$ & $0 \%$ & $0 \%$ & $0 \%$ & $0 \%$ & $0 \%$ & $0 \%$ & $0 \%$ & $0 \%$ & $0 \%$ & $0 \%$ & $0 \%$ & $50 \%$ & $0 \%$ \\
\hline \begin{tabular}{|l|}
1970 \\
\end{tabular} & $100 \%$ & $0 \%$ & $0 \%$ & $0 \%$ & $0 \%$ & $0 \%$ & $0 \%$ & $0 \%$ & $0 \%$ & $0 \%$ & $0 \%$ & $0 \%$ & $0 \%$ & $0 \%$ & $0 \%$ & $0 \%$ & $0 \%$ & $0 \%$ & $0 \%$ \\
\hline \begin{tabular}{|l|}
1971 \\
\end{tabular} & $80 \%$ & $0 \%$ & $20 \%$ & $0 \%$ & $0 \%$ & $0 \%$ & $0 \%$ & $0 \%$ & $0 \%$ & $0 \%$ & $0 \%$ & $0 \%$ & $0 \%$ & $0 \%$ & $0 \%$ & $0 \%$ & $0 \%$ & $0 \%$ & $0 \%$ \\
\hline \begin{tabular}{|l|}
1972 \\
\end{tabular} & $100 \%$ & $0 \%$ & $0 \%$ & $0 \%$ & $0 \%$ & $0 \%$ & $0 \%$ & $0 \%$ & $0 \%$ & $0 \%$ & $0 \%$ & $0 \%$ & $0 \%$ & $0 \%$ & $0 \%$ & $0 \%$ & $0 \%$ & $0 \%$ & $0 \%$ \\
\hline 1973 & $33 \%$ & $33 \%$ & $0 \%$ & $33 \%$ & $0 \%$ & $0 \%$ & $0 \%$ & $0 \%$ & $0 \%$ & $0 \%$ & $0 \%$ & $0 \%$ & $0 \%$ & $0 \%$ & $0 \%$ & $0 \%$ & $0 \%$ & $0 \%$ & $0 \%$ \\
\hline \begin{tabular}{|l|}
1974 \\
\end{tabular} & $100 \%$ & $0 \%$ & $0 \%$ & $0 \%$ & $0 \%$ & $0 \%$ & $0 \%$ & $0 \%$ & $0 \%$ & $0 \%$ & $0 \%$ & $0 \%$ & $0 \%$ & $0 \%$ & $0 \%$ & $0 \%$ & $0 \%$ & $0 \%$ & $0 \%$ \\
\hline \begin{tabular}{|l|}
1975 \\
\end{tabular} & $75 \%$ & $0 \%$ & $0 \%$ & $0 \%$ & $13 \%$ & $0 \%$ & $0 \%$ & $0 \%$ & $0 \%$ & $13 \%$ & $0 \%$ & $0 \%$ & $0 \%$ & $0 \%$ & $0 \%$ & $0 \%$ & $0 \%$ & $0 \%$ & $0 \%$ \\
\hline \begin{tabular}{|l|}
1976 \\
\end{tabular} & $29 \%$ & $12 \%$ & $6 \%$ & $12 \%$ & $6 \%$ & $6 \%$ & $12 \%$ & $6 \%$ & $0 \%$ & $6 \%$ & $0 \%$ & $0 \%$ & $0 \%$ & $0 \%$ & $0 \%$ & $0 \%$ & $0 \%$ & $0 \%$ & $6 \%$ \\
\hline \begin{tabular}{|l|}
1977 \\
\end{tabular} & $81 \%$ & $0 \%$ & $0 \%$ & $0 \%$ & $6 \%$ & $6 \%$ & $0 \%$ & $0 \%$ & $0 \%$ & $0 \%$ & $0 \%$ & $0 \%$ & $0 \%$ & $0 \%$ & $0 \%$ & $0 \%$ & $0 \%$ & $6 \%$ & $0 \%$ \\
\hline \begin{tabular}{|l|}
1978 \\
\end{tabular} & $100 \%$ & $0 \%$ & $0 \%$ & $0 \%$ & $0 \%$ & $0 \%$ & $0 \%$ & $0 \%$ & $0 \%$ & $0 \%$ & $0 \%$ & $0 \%$ & $0 \%$ & $0 \%$ & $0 \%$ & $0 \%$ & $0 \%$ & $0 \%$ & $0 \%$ \\
\hline \begin{tabular}{|l|}
1979 \\
\end{tabular} & $75 \%$ & $0 \%$ & $0 \%$ & $0 \%$ & $0 \%$ & $0 \%$ & $0 \%$ & $0 \%$ & $8 \%$ & $0 \%$ & $17 \%$ & $0 \%$ & $0 \%$ & $0 \%$ & $0 \%$ & $0 \%$ & $0 \%$ & $0 \%$ & $0 \%$ \\
\hline \begin{tabular}{|l|}
1980 \\
\end{tabular} & $80 \%$ & $0 \%$ & $0 \%$ & $0 \%$ & $10 \%$ & $0 \%$ & $0 \%$ & $0 \%$ & $0 \%$ & $0 \%$ & $0 \%$ & $0 \%$ & $0 \%$ & $0 \%$ & $0 \%$ & $0 \%$ & $0 \%$ & $10 \%$ & $0 \%$ \\
\hline \begin{tabular}{|l|}
1981 \\
\end{tabular} & $87 \%$ & $13 \%$ & $0 \%$ & $0 \%$ & $0 \%$ & $0 \%$ & $0 \%$ & $0 \%$ & $0 \%$ & $0 \%$ & $0 \%$ & $0 \%$ & $0 \%$ & $0 \%$ & $0 \%$ & $0 \%$ & $0 \%$ & $0 \%$ & $0 \%$ \\
\hline \begin{tabular}{|l|}
1982 \\
\end{tabular} & $78 \%$ & $11 \%$ & $0 \%$ & $0 \%$ & $0 \%$ & $0 \%$ & $0 \%$ & $0 \%$ & $0 \%$ & $0 \%$ & $0 \%$ & $11 \%$ & $0 \%$ & $0 \%$ & $0 \%$ & $0 \%$ & $0 \%$ & $0 \%$ & $0 \%$ \\
\hline \begin{tabular}{|l|}
1983 \\
\end{tabular} & $59 \%$ & $11 \%$ & $0 \%$ & $4 \%$ & $0 \%$ & $0 \%$ & $0 \%$ & $0 \%$ & $4 \%$ & $0 \%$ & $0 \%$ & $11 \%$ & $0 \%$ & $0 \%$ & $0 \%$ & $7 \%$ & $0 \%$ & $0 \%$ & $4 \%$ \\
\hline \begin{tabular}{|l|}
1984 \\
\end{tabular} & $55 \%$ & $0 \%$ & $0 \%$ & $0 \%$ & $0 \%$ & $0 \%$ & $0 \%$ & $0 \%$ & $9 \%$ & $0 \%$ & $9 \%$ & $0 \%$ & $0 \%$ & $0 \%$ & $0 \%$ & $18 \%$ & $0 \%$ & $9 \%$ & $0 \%$ \\
\hline \begin{tabular}{|l|}
1985 \\
\end{tabular} & $28 \%$ & $22 \%$ & $0 \%$ & $6 \%$ & $6 \%$ & $0 \%$ & $0 \%$ & $6 \%$ & $0 \%$ & $0 \%$ & $0 \%$ & $28 \%$ & $0 \%$ & $0 \%$ & $0 \%$ & $0 \%$ & $0 \%$ & $6 \%$ & $0 \%$ \\
\hline \begin{tabular}{|l|}
1986 \\
\end{tabular} & $43 \%$ & $21 \%$ & $0 \%$ & $0 \%$ & $7 \%$ & $0 \%$ & $0 \%$ & $0 \%$ & $0 \%$ & $0 \%$ & $0 \%$ & $14 \%$ & $0 \%$ & $0 \%$ & $0 \%$ & $0 \%$ & $0 \%$ & $7 \%$ & $7 \%$ \\
\hline \begin{tabular}{|l|}
1987 \\
\end{tabular} & $71 \%$ & $7 \%$ & $7 \%$ & $0 \%$ & $0 \%$ & $0 \%$ & $0 \%$ & $0 \%$ & $0 \%$ & $0 \%$ & $0 \%$ & $0 \%$ & $7 \%$ & $0 \%$ & $0 \%$ & $0 \%$ & $0 \%$ & $7 \%$ & $0 \%$ \\
\hline \begin{tabular}{|l|}
1988 \\
\end{tabular} & $78 \%$ & $0 \%$ & $0 \%$ & $0 \%$ & $22 \%$ & $0 \%$ & $0 \%$ & $0 \%$ & $0 \%$ & $0 \%$ & $0 \%$ & $0 \%$ & $0 \%$ & $0 \%$ & $0 \%$ & $0 \%$ & $0 \%$ & $0 \%$ & $0 \%$ \\
\hline \begin{tabular}{|l|}
1989 \\
\end{tabular} & $78 \%$ & $11 \%$ & $0 \%$ & $11 \%$ & $0 \%$ & $0 \%$ & $0 \%$ & $0 \%$ & $0 \%$ & $0 \%$ & $0 \%$ & $0 \%$ & $0 \%$ & $0 \%$ & $0 \%$ & $0 \%$ & $0 \%$ & $0 \%$ & $0 \%$ \\
\hline 1990 & $75 \%$ & $8 \%$ & $0 \%$ & $8 \%$ & $0 \%$ & $0 \%$ & $0 \%$ & $0 \%$ & $0 \%$ & $0 \%$ & $0 \%$ & $0 \%$ & $0 \%$ & $0 \%$ & $0 \%$ & $8 \%$ & $0 \%$ & $0 \%$ & $0 \%$ \\
\hline 1991 & $88 \%$ & $12 \%$ & $0 \%$ & $0 \%$ & $0 \%$ & $0 \%$ & $0 \%$ & $0 \%$ & $0 \%$ & $0 \%$ & $0 \%$ & $0 \%$ & $0 \%$ & $0 \%$ & $0 \%$ & $0 \%$ & $0 \%$ & $0 \%$ & $0 \%$ \\
\hline \begin{tabular}{|l|}
1992 \\
\end{tabular} & $50 \%$ & $50 \%$ & $0 \%$ & $0 \%$ & $0 \%$ & $0 \%$ & $0 \%$ & $0 \%$ & $0 \%$ & $0 \%$ & $0 \%$ & $0 \%$ & $0 \%$ & $0 \%$ & $0 \%$ & $0 \%$ & $0 \%$ & $0 \%$ & $0 \%$ \\
\hline \begin{tabular}{|l|}
1993 \\
\end{tabular} & $67 \%$ & $0 \%$ & $0 \%$ & $0 \%$ & $0 \%$ & $0 \%$ & $0 \%$ & $0 \%$ & $0 \%$ & $0 \%$ & $0 \%$ & $0 \%$ & $0 \%$ & $0 \%$ & $0 \%$ & $33 \%$ & $0 \%$ & $0 \%$ & $0 \%$ \\
\hline \begin{tabular}{|l|}
1994 \\
\end{tabular} & $100 \%$ & $0 \%$ & $0 \%$ & $0 \%$ & $0 \%$ & $0 \%$ & $0 \%$ & $0 \%$ & $0 \%$ & $0 \%$ & $0 \%$ & $0 \%$ & $0 \%$ & $0 \%$ & $0 \%$ & $0 \%$ & $0 \%$ & $0 \%$ & $0 \%$ \\
\hline \begin{tabular}{|l|}
1995 \\
\end{tabular} & $100 \%$ & $0 \%$ & $0 \%$ & $0 \%$ & $0 \%$ & $0 \%$ & $0 \%$ & $0 \%$ & $0 \%$ & $0 \%$ & $0 \%$ & $0 \%$ & $0 \%$ & $0 \%$ & $0 \%$ & $0 \%$ & $0 \%$ & $0 \%$ & $0 \%$ \\
\hline \begin{tabular}{|l|}
1996 \\
\end{tabular} & $50 \%$ & $50 \%$ & $0 \%$ & $0 \%$ & $0 \%$ & $0 \%$ & $0 \%$ & $0 \%$ & $0 \%$ & $0 \%$ & $0 \%$ & $0 \%$ & $0 \%$ & $0 \%$ & $0 \%$ & $0 \%$ & $0 \%$ & $0 \%$ & $0 \%$ \\
\hline \begin{tabular}{|l|}
1997 \\
\end{tabular} & $100 \%$ & $0 \%$ & $0 \%$ & $0 \%$ & $0 \%$ & $0 \%$ & $0 \%$ & $0 \%$ & $0 \%$ & $0 \%$ & $0 \%$ & $0 \%$ & $0 \%$ & $0 \%$ & $0 \%$ & $0 \%$ & $0 \%$ & $0 \%$ & $0 \%$ \\
\hline \begin{tabular}{|l|}
1998 \\
\end{tabular} & $75 \%$ & $0 \%$ & $0 \%$ & $0 \%$ & $0 \%$ & $0 \%$ & $0 \%$ & $0 \%$ & $0 \%$ & $0 \%$ & $0 \%$ & $0 \%$ & $0 \%$ & $25 \%$ & $0 \%$ & $0 \%$ & $0 \%$ & $0 \%$ & $0 \%$ \\
\hline
\end{tabular}




\section{APPENDIX C: $\quad$ House Coalitional Matrix}

On the following pages, is a matrix used to illustrate the witnesses present at the corresponding hearings for the selected analysis period. Although not shown, the coalitional matrix for the Senate is structured in the same format.

\begin{tabular}{|c|c|c|c|}
\hline Year & Agriculture & Civil Rights & Business \\
\hline 1935 & 36 & 1 & 7 \\
\hline 1936 & 1 & 0 & $\overline{0}$ \\
\hline 1937 & 12 & 0 & 2 \\
\hline 1938 & 4 & 0 & 2 \\
\hline 1939 & 4 & 0 & 0 \\
\hline 1940 & 16 & 2 & 6 \\
\hline 1941 & 18 & 0 & 5 \\
\hline 1942 & 0 & 0 & 0 \\
\hline 1943 & 13 & 2 & 5 \\
\hline 1944 & 65 & 11 & 18 \\
\hline 1945 & 5 & 1 & 5 \\
\hline 1946 & 1 & 0 & 0 \\
\hline 1947 & 45 & 1 & 10 \\
\hline 1948 & 7 & 0 & 2 \\
\hline 1949 & 33 & 0 & 3 \\
\hline 1950 & 16 & 0 & 3 \\
\hline 1951 & 13 & 0 & 0 \\
\hline 1952 & 0 & 0 & 0 \\
\hline 1953 & 48 & 0 & 7 \\
\hline 1954 & 1 & 0 & 0 \\
\hline 1955 & 17 & 0 & 1 \\
\hline 1956 & 451 & 0 & 2 \\
\hline 1957 & 16 & 0 & 0 \\
\hline 1958 & 31 & 0 & 0 \\
\hline 1959 & 22 & 0 & 0 \\
\hline 1960 & 21 & 0 & 0 \\
\hline 1961 & 75 & 0 & 2 \\
\hline 1962 & 74 & 0 & 4 \\
\hline 1963 & 0 & 0 & $\overline{0}$ \\
\hline 1964 & 18 & 0 & 1 \\
\hline 1965 & 8 & 1 & 0 \\
\hline 1966 & 8 & 0 & 1 \\
\hline 1967 & 11 & 1 & 0 \\
\hline 1968 & 60 & 0 & 4 \\
\hline 1969 & 2 & 0 & 0 \\
\hline 1970 & 18 & 0 & 0 \\
\hline 1971 & 73 & 0 & 51 \\
\hline 1972 & 1 & 0 & 0 \\
\hline 1973 & 52 & 0 & 34 \\
\hline 1974 & 91 & 0 & 22 \\
\hline 1975 & 100 & 0 & 21 \\
\hline 1976 & 170 & 0 & 26 \\
\hline 1977 & 267 & 0 & 64 \\
\hline 1978 & 184 & 0 & 42 \\
\hline
\end{tabular}




\begin{tabular}{|c|c|c|c|}
\hline 1979 & 321 & 0 & 61 \\
\hline \begin{tabular}{|l|}
1980 \\
\end{tabular} & 93 & 0 & 41 \\
\hline 1981 & 126 & 0 & 41 \\
\hline 1982 & 171 & 0 & 31 \\
\hline \begin{tabular}{|l|}
1983 \\
\end{tabular} & 164 & 0 & 77 \\
\hline \begin{tabular}{|l|}
1984 \\
\end{tabular} & 232 & 9 & 50 \\
\hline \begin{tabular}{|l|}
1985 \\
\end{tabular} & 289 & 1 & 100 \\
\hline \begin{tabular}{|l|}
1986 \\
\end{tabular} & 66 & 0 & 27 \\
\hline 1987 & 112 & 0 & 48 \\
\hline \begin{tabular}{|l|}
1988 \\
\end{tabular} & 15 & 0 & 12 \\
\hline \begin{tabular}{|l|}
1989 \\
\end{tabular} & 142 & 0 & 17 \\
\hline 1990 & 237 & 16 & 43 \\
\hline 1991 & 125 & 0 & 48 \\
\hline 1992 & 11 & 0 & 5 \\
\hline \begin{tabular}{|l|}
1993 \\
\end{tabular} & 35 & $\overline{0}$ & 9 \\
\hline \begin{tabular}{|l|}
1994 \\
\end{tabular} & 171 & 0 & 32 \\
\hline \begin{tabular}{|l|}
1995 \\
\end{tabular} & 301 & 0 & 60 \\
\hline 1996 & 9 & 0 & 12 \\
\hline 1997 & 5 & 10 & 24 \\
\hline \begin{tabular}{|l|}
1998 \\
\end{tabular} & 7 & $\overline{0}$ & 5 \\
\hline
\end{tabular}

